\title{
La Asociación de Cervantistas, 25 años*
}

\author{
José Manuel LuCÍA Megías ${ }^{1}$ \\ JOSÉ MONTERO REGUERA ${ }^{2}$ \\ SANTIAGO A. LÓPEZ NAVIA ${ }^{3}$ \\ MARÍA FERNANDA ABREU ${ }^{4}$ \\ ISABEL LOZANO-RENIEBLAS ${ }^{5}$ \\ ANTONIO BERNAT VISTARINI ${ }^{6}$ \\ FRANCISCO CUEVAS CERVERA ${ }^{7}$
}

\section{PRELIMINAR $^{8}$}

El pasado año 2013 se cumplió el vigésimo quinto aniversario de la creación de la Asociación de Cervantistas; su acta fundacional remite a febrero de 1988. Se trata de veinticinco años de intensa labor en pro del mejor conocimiento de la vida y obra cervantinas así como también del intercambio científico entre cervantistas de los cinco continentes.

Buena prueba de su actividad -a la que se podrían añadir otras muchasson los congresos y seminarios que se han celebrado desde 1990, que han supuesto un enriquecimiento de nuestra disciplina, cuyas actas publicadas pueden ahora consultarse en un portal específico inaugurado por el Centro Virtual del Instituto Cervantes en el $2013^{9}$.

* Esta contribución ha sido coordinada por José Manuel Lucía Megías y José Montero Reguera. Cada sección tiene un autor que figura en nota al pie en el epígrafe correspondiente.

1. Universidad Complutense de Madrid y Centro de Estudios Cervantinos.

2. Universidad de Vigo.

3. Universidad Internacional de La Rioja y Universidad internacional SEK (Santiago de Chile).

4. Universidade Nova de Lisboa.

5. Dartmouth College.

6. Universidad de las Islas Baleares.

7. Grupo de Estudios del Siglo XVIII de la Universidad de Cádiz.

8. Por José Manuel Lucía Megías y José Montero Reguera.

9. Accesible en: <http://cvc.cervantes.es/literatura/cervantistas/default.htm> (27.11.2014). 
Sí, en efecto, 25 años de una Asociación muy vital, con un enorme trabajo a las espaldas y con grandes proyectos y realidades para un futuro -presente- inmediato, que comienza por el próximo congreso internacional, celebrado por primera vez en tierras americanas (Sâo Paulo, junio-julio de 2015).

Por ello, propusimos en su momento a Anales Cervantinos la inclusión de un dossier sobre la labor de la Asociación durante estos años. Una necesaria mirada al pasado para afrontar con ilusión y con autoridad los desafíos del futuro, comenzando con las distintas celebraciones cervantinas que se sucederán en los próximos años (centenarios de la publicación de las Comedias y Entremeses, de la segunda parte del Quijote, del Persiles, y, ¡cómo olvidarlo!, la muerte de Cervantes).

Primeramente, algunos de los socios fundadores, ahora nuestros primeros socios de honor -Francisco Aguilar Piñal, Carlos Alvar, Aurora Egido, Frances Luttithuizen, Enrique Rull y José Carlos de Torres Martínez- evocan aquellos días de 1988 en que se dio forma a un proyecto sobre el que ya se venía dando vueltas desde algún tiempo atrás. En un segundo apartado, Santiago López Navia y María Fernanda de Abreu recuerdan a los dos primeros presidentes de la Asociación de Cervantistas, que lamentablemente ya no están entre nosotros: Alberto Sánchez -de quien en este año se cumple el centenario de su nacimiento- y José María Casasayas. Bajo el título general Pasado y presente, Antonio Bernat Vistarini, Isabel Lozano Renieblas, José Montero Reguera y Francisco Cuevas Cervera han valorado las dos grandes aportaciones de la Asociación al hispanismo: su condición de lugar de encuentro de cervantistas y cervantismos muy distintos por medio de no menos de una veintena de congresos y coloquios internacionales; y su acervo bibliográfico, hoy, además, al alcance de todo el mundo por medio de las herramientas informáticas. En manos de su actual presidente queda el capítulo final sobre los retos, desafíos y futuro inmediato de la Asociación de Cervantistas. Un apéndice registra la composición de todas las juntas directivas de la Asociación desde aquella primera elegida en el salón de sesiones del Excelentísimo Ayuntamiento de Alcalá de Henares el día 8 de abril de 1988, hasta la última, elegida en Oviedo el 14 de julio de 2012.

\section{EN LOS ORÍGENES DE LA ASOCIACIÓN DE CERVANTISTAS}

\subsection{Francisco Aguilar Piñal ${ }^{10}$}

Como socio Fundador de la Asociación de Cervantistas atiendo muy gustoso a la invitación que se me hace de hurgar en la memoria para conmemorar el $25^{\circ}$ aniversario de su constitución, en la que nunca tuve cargos de dirección

10. Profesor de Investigación jubilado. 
o de administración. No fue mía la iniciativa, sino que fui invitado a formar parte de la Asociación en febrero de 1988, como socio fundador, la misma propuesta que recibieron varios compañeros y amigos del Instituto de Filología, a requerimiento del entusiasta, eficaz y enérgico abogado mallorquín, José María Casasayas Truyols, verdadero padre y artífice de la idea, que contaba con la generosa colaboración del amigo de todos, el gran profesor y fiel cervantista Alberto Sánchez, nombrado primer presidente de la Asociación. Por tanto, me limitaré a recordar aquellos primeros años y a dar cuenta de mi contribución a los estudios cervantinos.

En mi condición de investigador del Consejo Superior de Investigaciones Científicas, dedicado especialmente al estudio literario y humanístico de nuestro siglo XVIII, en la sede madrileña del Instituto de Filología, he tenido oportunidad en varias ocasiones de tratar el tema cervantino, como siglo crucial que es en la biografía y la crítica de las obras de Cervantes. Mi primera colaboración en la revista Anales Cervantinos fue en el número correspondiente al año 1960, en el que daba noticia de «Un comentario inédito del Quijote en el siglo XVIII», debido a la pluma del escritor Cándido María Trigueros, sobre el que comenzaba a investigar su vida y su obra.

Cuando Casasayas me propuso incorporarme a la Asociación que tenía prevista, ya conocía él mi interés por Cervantes, porque había reseñado dos libros importantes de esos años: Cervantes y los casticismos españoles, de Américo Castro (1967) y Realismo mágico de Cervantes, de Arturo Serrano Plaja (1967). Además, había publicado en los Anales de Literatura Española «Anverso y reverso del quijotismo en el siglo XVIII» (1982) y en Anales Cervantinos «Cervantes en el siglo XVIII» (1983). Así que, cinco años después, estampaba mi firma en el acta fundacional de la Asociación.

Los años noventa supusieron para mí un trato frecuente con el siempre animoso Casasayas, a pesar de sus dolencias, a quien visité en su casa de Mallorca. Me enseñó su espléndida biblioteca y me habló con pasión de su traducción del Quijote al mallorquín, que estaba culminando. Después he sabido que, de su propio bolsillo, imprimió solamente ocho ejemplares para sus nietos, porque ninguna editorial quiso hacerse cargo de la obra, única en su género, ya que supera a la de Ildefonso Rullán (1905) al haber traducido incluso las poesías, con innumerables citas a pie de página, que testifican su enorme capacidad de trabajo (durante más de 40 años) y el profundo conocimiento, no solo de la obra original, sino de las infinitas traducciones (que poseía) y de los estudios más importantes aparecidos desde el siglo XVIII. Recuerdo la amabilidad de toda su familia, así como el afán coleccionista de las pequeñas pilas de agua bendita de cerámica que colgaban de las paredes de su casa. Naturalmente, no pude marcharme de allí sin saborear los jugosos pastelillos de su afamada pastelería.

Cervantes se cruzó de nuevo en mi camino al estudiar a Trigueros, dando origen a mi colaboración en el homenaje a mi profesor y amigo Francisco López Estrada, «La continuación de La Galatea por Trigueros» (Dicenda, 1990). También escribí otra colaboración sobre «Trigueros, cervantista», para 
la Gran Enciclopedia Cervantina. Años después aparecieron «Un 'quijote' valenciano: el Setabiense» (Anales cervantinos, 1998), y «El cervantismo de la Real Academia Sevillana de Buenas Letras», en el Homenaje al amigo y compañero de Instituto, también fundador de la Asociación, Juan María Díez Taboada (1998).

Casasayas fue también el organizador de los primeros congresos de la Asociación, el primero en Barcelona, el segundo en Nápoles, y el tercero en Menorca (1997). Este último fue particularmente agradable, no solo por la sede escogida, en el Hotel de Cala Galdana, sino por la temática y las ponencias, al ser convocado con el título Primer Convivio internacional. De locos amenos. Sobre las desviaciones lúdicas en la crítica del Quijote. De allí salió mi estudio sobre «El Anti-Quijote, de 1805». Disfruté mucho en aquellos días.

Con motivo del centenario (2005), publiqué algunas colaboraciones en el mes de enero en el Diario de Sevilla: «El Quijote de 1604», «Sevilla y Don Quijote en 1905», «Cervantes y la calle Feria» y «Despidiendo a Don Quijote».

Finalmente, con una osadía provocadora, propuse un escandaloso interrogante en un serio acto académico en recuerdo del director de mi tesis de Doctorado, el amable y recordado catedrático de Sevilla, Francisco López Estrada, gran cervantista. Ante la docta concurrencia, en el salón de actos de la Real Academia Sevillana de Buenas Letras, de la que soy académico Preeminente y de Honor, me atreví a preguntar: «¿Quién escribió el Quijote?». Aunque parece una pregunta retórica, digna de una gran carcajada y del repudio unánime de todos cuantos, en los cinco continentes, han leído y aplaudido, desde el mismo día de su publicación, la gran novela, el fondo de la argumentación no carece de algún sentido. No se lleva a juicio la maravilla literaria, sino la paternidad de la obra.

En efecto. ¿No es lícito preguntarse cómo es posible que ese personaje, nacido en Alcalá de Henares, soldado herido, vejado cobrador de impuestos por Andalucía, preso en varias ocasiones, cautivo en Argel, que siempre vivió de posada en posada, fuera el mismo autor de una novela que cita a más de trescientos autores clásicos, que había leído y recordaba punto por punto escenas, nombres y protagonistas de todos los libros de caballerías?

Cuantos datos conocemos de su biografía nos llevan la imaginación por otros caminos. ¿Dónde y cuándo leyó tanto y se impregnó de toda la literatura anterior? Si no tenía casa propia, ¿dónde guardó tantos cientos de folios y apuntes necesarios para escribir una de las obras cumbres de la literatura universal?

La disyunción me parece clara. O Miguel de Cervantes Saavedra -el que conocemos- no es el autor de obra tan excelsa, o es un milagro de la naturaleza, y habremos de rendir un culto casi religioso a ese cerebro sin par que todo lo recuerda y que es capaz de ser el supremo maestro de la lengua española, entre las pestilentes celdas de la cárcel sevillana. Nada me gustaría más que los sabios cervantistas que me lean recojan este guante y se inicie una «tertulia» universal para dirimir quién fue el verdadero autor del Ingenioso hidalgo Don Quixote de la Mancha. 


\subsection{Carlos Alvar ${ }^{11}$}

Los orígenes de la AC se vinculan directamente al CSIC y a Alcalá de Henares, y a la "peregrina" personalidad de José María Casasayas. No soy yo quien debe hablar del Consejo, pues hay entre nosotros quienes conocen muy bien lo que ocurría en los pasillos de Medinaceli 4, pero se me permitirá un breve excurso autobiográfico. Mis orígenes "oficiales"como investigador comenzaron en el CSIC, del que fui colaborador científico gracias a un tribunal presidido por Emilio Alarcos Llorach y del que formaba parte José Carlos de Torres (era el año 1977): mi relación con los estudiosos del CSIC han sido cordiales desde entonces hasta ahora.

Cuando Casasayas quiso entrar en contacto con Alcalá de Henares, en 1987, se encontró con el apoyo de las autoridades municipales y universitarias. El vicerrector de Extensión Universitaria en ese momento era yo mismo, de forma que no fue extraño, sino más bien un resultado natural, que se desviara hacia mí la iniciativa que planteaba Casasayas y en la que quería involucrar al Ayuntamiento y a la Universidad de Alcalá. Para entonces, ya habían estado en mi casa José Carlos de Torres y Casasayas para que firmara la solicitud de creación de la AC. A partir de ese momento, mi vinculación con la AC fue continua y sistemática, en activo en la Junta Directiva, o como apoyo desde el Centro de Estudios Cervantinos.

Los años finales de la década de los 80 fueron época de gran ebullición económica y siguieron siéndolo hasta que los fastos del 92 nos sumieron en una profunda crisis, relativamente breve en comparación con la actual. El Alcalde de Alcalá, Florencio Campos, tenía intención de crear un Instituto Cervantino, capaz de mover el turismo cultural en la ciudad para que Alcalá adquiriera un rango comparable al de Stratford-upon-Avon con respecto a Shakespeare. Supongo que era la forma de justificar unos valores suficientes para nuevos proyectos: por entonces nació el Instituto Cervantes y las fuerzas vivas de Alcalá hicieron lo posible para que la sede central ocupara el Colegio del Rey, hasta entonces sede de la Fundación municipal que se dedicaba a la cultura. Se comprende de inmediato que se produjeran confusiones -supongo que no todas inocentes- y que funcionaran las "sinergias", término muy en boga en aquella época. Se aceptó con entusiasmo la creación de la AC, pues venía a sumar un nuevo elemento a la oferta cultural de la ciudad, con la idea siempre de atraer un turismo selecto, y en cierta medida, también, como forma de oponer la capacidad del Ayuntamiento en cuestiones "académicas", frente a una Universidad que era vista como una invasora de las competencias municipales en urbanismo (y no sólo).

Se explica así que la constitución de la AC tuviera lugar en el salón de plenos del Ayuntamiento, como si fuera una iniciativa popular surgida de la propia ciudad. También en el salón de plenos se constituyó dos años más

11. Universidad de Ginebra, Universidad de Alcalá y Centro de Estudios Cervantinos. 
tarde el Centro de Estudios Cervantinos, con la presencia del ministro de Cultura (Jorge Semprún), del presidente de la Comunidad de Madrid (Joaquín Leguina), el alcalde de Alcalá (Florencio Campos) y el rector de la Universidad (Manuel Gala): todos ellos eran miembros del PSOE o muy cercanos a esta formación política. Todos ellos decidieron que fuera yo el director del nuevo organismo creado, el Centro de Estudios Cervantinos. Casasayas estuvo en el acto oficial de la firma de los Estatutos del nuevo Centro, pues veía las posibilidades de proyección de su idea, y entendía que nuestra sede en el Palacio Laredo podía ser también la base de operaciones de la AC: al fin y al cabo, los objetivos eran comunes. Desde entonces mantuvimos una relación continua, cedimos algún pequeño espacio a la $\mathrm{AC}$ en nuestros locales, y la visita de Casasayas se convirtió en una presencia habitual entre nosotros (aún guardamos su ajedrez de aquellos años).

La organización del I Congreso Internacional de la AC en Alcalá de Henares (1988) y de otras actividades en los años siguientes habían obligado a un trabajo conjunto; la creación del Centro de Estudios Cervantinos facilitaba esa relación y podría responder a unas expectativas por parte de Casasayas que no se correspondían con la realidad cotidiana.

Es innecesario trazar la semblanza del promotor de la AC; bastará decir que le gustaba que las cosas fueran como él quería y cuando él decía. Su carácter vehemente le cerró no pocas puertas, y sus deseos imperativos con frecuencia, provocaban situaciones incómodas; pero esos mismos rasgos le franquearon otros caminos. No descubro nada nuevo. Procurábamos aliviar las tensiones aludiendo a su escasa experiencia con las normas académicas, pues no en vano procedía del mundo de la abogacía (aunque había trabajado poco en este terreno, por motivos que contaba con picardía) y de la empresa privada. No extrañará, pues, que nuestra relación tuviera altibajos, ya que al comienzo de los años 90 ambos teníamos que definir el ámbito de nuestras actuaciones en el cervantismo: él, nacido en 1927, veía cómo el tiempo pasaba con rapidez; yo, un cuarto de siglo más joven, tenía una perspectiva distinta.

Nuestros encuentros fueron numerosos, hasta pocos días antes de la embolia fatal en 2004: habíamos estado preparando actividades para el 2005, en el Hotel Moderno de Madrid. En Alcalá de Henares, en Palma de Mallorca, en Madrid y durante los congresos. Siempre había largos encuentros organizativos e intercambio de pareceres, y también ratos para hablar de innumerables cosas, no siempre cervantinas.

No resulta fácil separar la AC de los inicios y la figura de su fundador, como no me resulta fácil, tampoco, aislar los elementos personales del destino del CEC. Muchas veces me pregunto hasta dónde llegaba José María Casasayas y dónde empezaba el presidente de facto de la AC. Su visión absolutamente personalista era necesaria para transmitir el entusiasmo y responder con el mismo entusiasmo a las muestras de afecto de los socios; pero a la vez, una negativa institucional, se convertía en un enfrentamiento personal. Situaciones delicadas. Sin embargo, y a pesar de todo, el hecho más importante ha sido, 
sin duda, que la $\mathrm{AC}$ y el CEC han caminado juntos durante más de veinticinco años. Ahora, el CEC se reestructura como Instituto de investigación, y la AC mantiene con dinamismo el rumbo académico que han sabido marcar sus presidentes posteriores, José Montero Reguera y José Manuel Lucía Megías.

\subsection{Aurora Egido ${ }^{12}$}

Un apellido como el de José María Casasayas remite automáticamente en el «imaginario» colectivo (término que la RAE solo admite como sustantivo) a una casa, propiedad de alguien llamado Sayas a quien todos conocen. Y a ese reclamo, más allá del Pep, del Josep o del extendido José María, apelaba el simple enunciado de "Casasayas»: un hombre y un nombre que daba cobijo a quienes lo conocían y conformaban el ancho mundo de los cervantistas.

Persona singular, de las que ya no quedan, lo debió haber sido mucho antes de que yo lo conociera, cuando una buena mañana de febrero de 1988 apareció con cara de notario en mi despacho de la Facultad de Filosofía y Letras de la Universidad de Zaragoza. Esa ciudad, a medio camino entre Barcelona y Madrid, como se desprende de la Historia de España y del buen pasaje que Aragón ha supuesto siempre entre Cataluña y Castilla, le venía de perlas para hacer un alto. El documento que me extendió, con todo lujo de explicaciones previas y para el que solicitaba mi firma, iba en dirección de Alcalá de Henares, para formalizar allí legalmente la Asociación de Cervantistas. Él era cervantista de pleno derecho y en grado superlativo, pero quería agavillar bajo un cielo protector a otros muchos, creando una entidad que les sirviera de cobijo e impulsara el estudio de la obra cervantina. Casasayas lo hizo con una mentalidad que dejaría atónitos a los actuales maestros en economía de mercado.

Como recordó su amiga Helena Percas de Ponseti (2004), el Acta Fundacional de la Asociación de Cervantistas (4/2/1988) la suscribimos quince personas, que tal vez no éramos conscientes del privilegio que ello suponía. Pues el verdadero mérito era del último firmante: José María Casasayas Truyols, que cumplía así un sueño alimentado desde que leyó el Quijote cuando una enfermedad lo dejó encamado a los trece años.

El hecho de haber leído la obra de Miguel de Cervantes y la mayor parte de lo que se había escrito sobre ella, guardados en su magín y en su magnífica biblioteca, lo situaba en un lugar privilegiado para afrontar la tarea que entonces se propuso, arropada además por sus conocimientos como abogado y una voluntad de hierro. No entraré en el menudo de sus publicaciones, bien atendido por otros autores que han trazado su semblanza y la historia de la Asociación de Cervantistas, de sus congresos (por ejemplo, José Montero Reguera (2004d), y Santiago López Navia (2008).

12. Universidad de Zaragoza. 
Tampoco me detendré en las entretelas de un jugoso anecdotario, bien conocido por quienes le acompañaron asiduamente a lo largo de los años, como Carlos Romero, Daniel Eisenberg (2004) y Anthony Close, entre otros, como Alicia Villar. Antonio Bernat Vistarini, conocía de primera mano su trabajos y sus días mallorquines, y cuanto supuso la tarea de incorporar la riquísima biblioteca de Casasayas a la Universitat de les Illes Balears.

Tan solo querría resaltar la casi inabarcable proyección de sus afanes cervantinos y su tenaz empresa a la hora de vincular a las instituciones y a las fuerzas vivas, organizando coloquios y congresos cervantinos o ayudando a los jóvenes investigadores. Por eso me alegró la creación del «Premio de Investigación Cervantina José María Casasayas» por el Ayuntamiento de Argamasilla de Alba, y el reconocimiento que su trabajo fue adquiriendo, siendo galardonado en su tierra con el Premio «Ramon Llul», al igual que en otros foros.

Desearía destacar dos cualidades suyas: la pasión y la entereza, pues sin ellas no se explica ni su trayectoria profesional y vital, ni su capacidad para sobreponerse a golpes tan duros como la pérdida de su esposa Luisa en un accidente de tráfico, o las secuelas de su última enfermedad. Inasequible al desaliento, Casasayas fue, algo más que «un cochero», tirando, como él decía, del carro de la Asociación de Cervantistas (incluso haciendo como el sastre del Campillo, que cosía de balde y ponía el hilo).

No quisiera olvidar los regios bombones y exquisitos mazapanes de Can Frasquet, reconocidísima pastelería mallorquina, donde, utile dulci, Casasayas fue configurando su biblioteca cervantina, ni cuando hice ocasionalmente de intermediaria para conseguirle entradas en la ópera de Viena. Sus gustos musicales corrían parejos con los cervantinos, ya que frecuentaba con igual gusto y dominio los episodios del Quijote, la música de Bach y las óperas de Wagner. Recuerdo una tarde en Venecia, junto a él y su esposa, cogiendo un vaporetto rumbo a una iglesia donde íbamos a escuchar un concierto de música barroca; momento en el que me apabulló con sus conocimientos musicales.

En estos tiempos de especialización absoluta y pensamiento fragmentado, resulta confortante recordar los amplios y variados conocimientos de José María Casasayas, que además de su propio trabajo como investigador y traductor, puso todo cuanto tenía y sabía para proyectar, donde fuera necesario, la figura de Miguel de Cervantes, y alentando siempre a los demás. Buen jugador de ajedrez, se sentía tan libre como los pájaros que tanto amaba. $\mathrm{Su}$ buen humor y su amor a la vida parecían sacados de ese «otro yo» que fuera para él don Quijote de la Mancha, aunque tuviera, como Sancho, los pies en el suelo. Vehemente y tranquilo a la vez, Casasayas parecía encarnar, por todo ello, el lema clásico «Festina lente».

En una ocasión escribió que ser cervantista era como ser poeta: una enfermedad incurable y sobre todo contagiosa. También lo fueron el impulso, la sonrisa abierta, la amistad, el cariño y la generosidad que desprendían los hechos y dichos memorables de quien presumía ser «un pobretó mallorquí, insulà al cap darrer», con todo lo que ello significa cuando se ha hecho con humildad una obra como la suya. Pues José María Casasayas, como el geógrafo Martín Cortés, sabía muchísimo «de la arte de navegar». 


\subsection{Frances Luttikhuizen ${ }^{13}$}

A muchas personas les puede parecer extraño que yo -que no soy ni hispanista ni cervantista, sino licenciada en filología anglo-germánica- sea una de los miembros fundadores de la Asociación de Cervantistas. De hecho, entré en el mundo cervantino por pura casualidad. Después de terminar la carrera de filología en la Universidad de Barcelona y haber ganado las oposiciones a cátedra de instituto, me matriculé en los cursos de doctorado. Cuando llegó el momento de elegir un tema de tesis, he de confesar que andaba un poco perdida pues eran muchos los temas que me atraían.

Me sacó de dudas el Dr. Pedro Guardia cuando sugirió un tema de literatura comparada relacionado con la traducción. En aquel entonces - principios de los ochenta- se habían iniciado en otros departamentos de inglés estudios de las traducciones al inglés de los clásicos españoles. Al Dr. Guardia le fascinaba la figura de James Mabbe. Ya se habían hecho tesis sobre su traducción de La Celestina y del Guzmán de Alfarache, pero faltaba un estudio exhaustivo sobre su traducción de las Novelas ejemplares. Así que me adjudicaron el tema sin que yo realmente supiera mucho ni sobre teoría de la traducción ni tampoco sobre las Novelas ejemplares. No me podía haber ido mejor otro tema. Aprendí mucho sobre traducción y me enamoré de las Novelas ejemplares y de su autor. Un día, comentando mi trabajo con mi colega María Luisa del Álamo, me recomendó que la próxima vez que viajara a Palma de Mallorca -donde mi hijo estaba haciendo el servicio militar- fuera a ver a un tal José María Casasayas. Así fue cómo le conocí en su estudio encima de la Pastisseria Can Frasquet. Quedé muy impresionada y creo que el sentir fue mutuo. Por aquel entonces, José María había conocido -también por casualidad- a Helena Percas y le dio mi dirección.

Continué con mis investigaciones y cotejos durante varios veranos enteros en la Biblioteca de Cataluña. Vi que el criterio de los traductores variaba mucho, pero me fascinaron especialmente las variantes textuales, sobre todo en las traducciones más fieles. Así, en la defensa de mi tesis expresé mi preocupación sobre este tema. Al terminar la defensa, el Dr. Blecua, presidente del tribunal, me explicó que esto era debido al texto base que utilizaban dichas traducciones y me invitó a hacer un estudio de todas las ediciones españolas para trazar un árbol genealógico en base de las variantes textuales que presentaban. Y ni corta ni perezosa me lancé a la tarea.

Para entonces José María Casasayas ya estaba ultimando los formalismos para crear una asociación de cervantistas y me invitó a ser uno de los diez miembros firmantes necesarios para tal proyecto. Todavía recuerdo aquella sala de plenos en el Ayuntamiento de Alcalá de Henares. Llovía a cántaros. El año siguiente José María ya empezó a organizar los coloquios. Asistí a casi todos, siempre con un gran complejo de inferioridad aunque, por otro lado,

13. Canet de Mar (Barcelona). 
también me atrevía a profundizar en aspectos de las Novelas ejemplares poco trabajados. Así fue cómo, poco a poco, fui abriéndome paso entre los grandes eruditos en parcelas marginales del cervantismo. No obstante, independientemente de mis trabajos relacionados con las Novelas ejemplares, creo humildemente que mi aportación más notable ha sido mi estudio de las primeras ilustraciones del Quijote, un trabajo realizado gracias al apoyo de Carlos Alvar, quien siempre me ha animado a continuar investigando.

Mi gratitud a la Asociación de Cervantistas es inmensa. Ahora ya me voy haciendo mayor y no creo que pueda asistir a muchos más congresos, pero os llevaré siempre en mi corazón. Le deseo larga vida a la Asociación y muchos éxitos a todos vosotros y a vuestros proyectos.

\subsection{Enrique Rull14}

Para conmemorar el 25 aniversario de la Asociación de Cervantistas me pide la dirección de la misma un recuerdo de la memorable ocasión que nos llevó a participar en la fundación de dicha Asociación. Como quiera que es ya una ocasión sobre la que ha pasado un tiempo considerable, espero que mi memoria no me traicione con los detalles que puedo recordar al respecto. No me voy a detener en aquellos aspectos más objetivos y de crónica oficial de la empresa, que ya fue tratada en otra publicación por otro socio fundador, José Carlos de Torres ${ }^{15}$, sino que, ya que se me da vía libre para que publique mis impresiones y recuerdos personales, haré más una crónica de impresiones que de sucesos. Tendríamos que preguntarnos varias cosas: qué nos llevó a crear esta querida fundación, cómo y en qué circunstancias lo hicimos y cuáles eran los fines que perseguíamos. Respecto de lo primero, tengo que decir que la motivación fundamental era y es (de eso no puede caber la mínima duda) el amor a la obra cervantina como estudiosos, editores y familiarizados con la misma, como éramos el grupo general que participamos en esa labor fundacional. Todo ello movido por la mano eficaz, entusiasta y desprendida de la cabeza (entonces visible, y para nosotros siempre lo será, de D. José María Casasayas, pese a que ya no esté entre nosotros). Puedo rememorar las circunstancias del acontecimiento, el lugar y la ocasión. Estábamos entonces (hacia finales del año 1987 o principios de 1988; como la fundación oficial tuvo lugar en abril del año 1988, presumo que el acta que firmamos los presentes entonces, sería unos meses antes) en el edificio del CSIC de la calle Duque de Medinaceli 4, de Madrid. Íbamos allí regularmente a consultar la riquísima biblioteca del Instituto «Miguel de Cervantes» (precisamente), donde además trabajábamos unos como investigadores, otros como colaboradores científicos y otros como profesores universitarios. 
A la biblioteca del Instituto acudía un tipo bien parecido, simpático y agradable, que no era filólogo oficial pero que hablaba con cualquiera ya fuera de Cervantes o de cualquier tema. Era, como ya se habrá adivinado, José María Casasayas. Entonces trabajaba en Anales cervantinos D. Alberto Sánchez, alma y corazón de la revista, infatigable cervantista y reconocido especialista en todo el mundo sobre la figura y obra de nuestro autor. También estábamos, concretamente en el despacho 14 (no lo olvido) Juan María Díez Taboada, Juan Manuel Rozas, Luciano García Lorenzo, José Carlos de Torres y yo mismo, cada uno de generaciones distintas: los dos primeros profesores de una generación algo anterior, y los tres últimos, en cierto modo, discípulos suyos, con especialidades distintas pero con la misma devoción por el Siglo de Oro y su máximo exponente narrativo. Por allí iban de visita de estudio algunos especialistas (entre los cuales figuran algunos socios fundadores) como son José Ares Montes de la Universidad Complutense de Madrid (de literatura portuguesa, de quien fui alumno), Alberto Blecua (profesor de la Universidad de Barcelona, conocido cervantista vocacional, editor del gran autor y amigo cordial de todos sus amigos). Otros, como Francisco Aguilar Piñal conocido investigador del siglo XVIII, que tenía, en la misma planta del 14, despacho propio.

El encuentro colectivo con José María era cuestión de tiempo (ya habíamos tenido ocasión de verle en la biblioteca innumerables veces), y un feliz día que estábamos reunidos en el despacho mencionado algunos de los susodichos se presentó en el 14 José María con una propuesta insólita: quería fundar una Asociación de Cervantistas. Para ello pensaba involucrar a Don Alberto Sánchez, a Anales Cervantinos, al Instituto «Miguel de Cervantes» del CSIC y al grupo (entonces incompleto e incipiente) de los que estábamos allí reunidos, que pensaba ampliar rápidamente pidiendo colaboración a otros profesores (como son los que figurarán en el Acta fundacional de la Asociación). Inmediatamente, como es lógico, la idea nos pareció fantástica (en los dos sentidos, el encomiástico y el literal). Nos parecía de todo punto imposible que con los medios con los que contábamos se pudiese llevar a cabo tal empresa, sobre todo desde el punto de vista organizativo y económico. No sabíamos entonces de las facultades organizativas y de abnegación de José María para tal empresa, que eran infinitas. Algunos le aconsejamos que se titulase Asociación Internacional, pero él (que llevaba todo preparado) dijo que no era necesario, que con «Asociación de Cervantistas» se reuniría a todo el mundo científico que estuviera interesado en la gran figura, y, como sabemos por lo que ha venido después, no andaba descaminado, pues ese interés es general como lo muestra la Asociación que cuenta con colaboradores de todas la nacionalidades y geografías. La labor que se pretendía era estudiar la obra cervantina, crear congresos de la Asociación, reuniones periódicas de profesionales, ampliar la visión de la obra de Cervantes no solo al estudio del Quijote sino del resto de su obra, que rápidamente se extendió a ella, como muestran varios congresos que se dedicaron, por ejemplo, al Persiles (que desde entonces es tema suficientemente conocido por todos a partir de estudios de los principa- 
les colaboradores de la Asociación y de otros investigadores), obra entonces menospreciada por la crítica y hoy valorada como otra obra que se puede parangonar con la primera de nuestras letras. Ya no recuerdo si fue antes de la creación de la Asociación o después, en un viaje de trabajo que hice a Mallorca, pude ver a José María en su ambiente de estudio: ¡una exquisita pastelería! en cuyos bajos tenía un despacho en donde estaba gestando ni más ni menos que la traducción del Quijote al mallorquín (labor que finalmente llevó a cabo con total solvencia años después). Entonces no había ordenadores y me sorprendió ver que utilizaba para escribir una máquina eléctrica con unas «margaritas» de tipografía varia que a mí me parecieron verdaderamente revolucionarias dentro de la técnica de aquellos años.

Un vez creada la Asociación, fue dirigida al principio con mano de hierro por José María (al que no arredraba la terrible enfermedad que padeció) y que, pese a los problemas y dificultad que tuvo para expresarse con soltura, supo mantenerse en la dirección con ánimo redoblado. Todavía recuerdo un viaje en «tren nocturno a Lisboa», al Congreso de 2003 en donde nos pasamos gran parte de la noche en el mismo vagón-restaurante discutiendo de grabaciones de música, a la que tan aficionados éramos ambos, y en donde ni el ruido del tren ni sus dificultades para expresarse con claridad mermaron un punto su afán y su entusiasmo. Ese viaje fue para mí como el cierre de una etapa en la que simbólicamente sería una de las últimas veces que hablaríamos largo y tendido José María y yo. Tampoco quiero olvidar aquí a quien fue su mano derecha en el apoyo institucional de entonces: la entrañable y entregada siempre Alicia Villar, compañera en ese viaje y en otros muchos. La muerte de José María no ha significado un cambio ni de ideales, ni de entusiasmo ni de colaboraciones eficaces, antes bien la Asociación ha crecido en todos los órdenes y a otros compete hacer la crónica de estos últimos años. Y aunque esto, más que una crónica de la Asociación y de su fundación (como ya advertía antes), empieza a parecer un recuerdo de las personas que la hicieron posible, estoy seguro que me lo perdonarán todos los colaboradores de la Asociación, como me lo perdonaría el gran autor del Quijote y del Persiles. Y como igualmente me lo perdonarán algunas personas que no figuran en este itinerario fundacional, cuyo recuerdo, después de estos años, ha podido borrárseme de aquel acto. Después vendría lo que ya es una historia reciente y que no me compete analizar. Quede esta sencilla página como rememoración personal y cordial de un acontecimiento verdaderamente histórico.

\subsection{José Carlos de Torres Martínez ${ }^{16}$}

A las 12 horas del día 8 de abril, en el Salón de Sesiones del Exmo. Ayuntamiento de la ciudad de Alcalá de Henares, celebramos la primera asamblea

16. Consejo Superior de Investigaciones Científicas, CSIC. 
general extraordinaria los miembros presentes y representados de la nueva Asociación de Cervantistas (AC). La ceremonia fue bastante emotiva, al menos para mí; nos dirigió unas acogedoras palabras de bienvenida y apoyo institucional el Ilmo. Sr. Alcalde, don Florencio Campos Corona (PSOE). Después se ausentó tras habernos dicho que tal sala era nuestra para el acto que celebrábamos ${ }^{17}$.

Llevó la voz cantante, como apoderado general, José M. ${ }^{a}$ Casasayas, por lo que fue nombrado por los presentes vicepresidente ejecutivo y se designó presidente a D. Alberto Sánchez, tesorero a Juan M. ${ }^{a}$ Diez Taboada y yo fui nombrado secretario. José M. ${ }^{a}$ podía, mejor que nadie, dedicar tiempo (y dinero) para crear, mover y convencer a personas, así como a dirigirse a las instituciones. Entonces él era bibliófilo y bibliógrafo del tema cervantino, aunque después llegó a investigar (se planteó, entre otros temas, el tiempo literario en el «Quijote»...).

¿Cuándo conocí la posibilidad de crear la AC? Lo referí en mi trabajo «La empresa romántica de la Asociación de Cervantistas», en las Actas del XII $C I A C$. Fue hacia el año 1976, cuando conocimos a José M. ${ }^{\mathrm{a}}$, Juan M. ${ }^{\mathrm{a}}$ Diez Taboada y yo, al visitarnos en nuestro despacho de Duque de Medinaceli 6 (CSIC). El ya trataba a D. Alberto en el CSIC. Mi experiencia en la organización de congresos y simposios internacionales fue de gran utilidad; con el tiempo, él también aprendió a hacerlo mucho mejor que yo. En estos años, hasta 1988, nos vimos muchas veces, llegando a trascender la relación hacia una amistad de las dos familias.

Gracias a la asociación he podido conocer a tantos cervantistas y hacerme amigo de muchos de ellos. Una suerte para mí.

\title{
2. GALERÍA DE PRESIDENTES
}

\subsection{Don Alberto Sánchez en el recuerdo ${ }^{18}$}

\author{
«...maestro \\ humilde y sabio sin teatraleo, \\ humanista humanísimo, dilecto, \\ de quien recuerdo \\ tantas lecciones, bueno \\ tal Alonso Quijano ingenuo, \\ como él en lo cierto, \\ por días y trabajos lleno \\ de la pasión que da conocimiento».
}

Ramón de Garciasol

17. Véase Torres Martínez (2008).

18. Por Santiago A. López Navia. 


\section{«Lector ilustre» (Quijote, II, Prólogo)}

Uno de los momentos más singulares y entrañables del III Congreso Internacional de la Asociación de Cervantistas, celebrado en la isla de Menorca en un precioso otoño mediterráneo de 1997, se produjo ese día en el que una joven congresista preguntó ilusionada a la organización cuándo estaba prevista la llegada de Américo Castro. A pesar de que de forma paralela al congreso se celebró el inolvidable primer y hasta ahora único «Convivio Internacional de los Locos Amenos», que tanto regocijo supuso para los congresistas en aquellas tardes, aquello no era una broma macabra, sino una conmovedora muestra de reverente desinformación que tal vez podría haberla llevado a interesarse, por ejemplo, por la presencia de Clemencín, Hartzenbusch o Mayans i Siscar. Después de muchos coloquios y congresos cervantistas a la espalda, sé que pasan estas y otras cosas más pintorescas que podrían servir para escribir un anecdotario sorprendente donde los haya.

Un poco mejor informado, pero con el mismo grado de reverente interés, me acogí yo un día al ofrecimiento de Alicia Redondo Goicoechea, profesora de la Universidad Complutense de Madrid y directora de mi tesis doctoral, de mediar para que Alberto Sánchez me hiciera la merced de recibirme y orientarme en mis investigaciones cervantistas, dirigidas ya desde hacía algunos años al estudio de la ficción autorial en el Quijote y su huella en las obras de la narrativa hispánica inspiradas en el modelo. Y Don Alberto me hizo, en efecto, la merced de recibirme, nada menos que un sábado y en su casa del n. ${ }^{\circ} 323$ de la madrileña calle de Alcalá, a donde dirigí desde entonces tantas cartas y desde donde recibí otras tantas, siempre cargadas de afecto y sabiduría. Han transcurrido ya veintisiete años desde entonces (yo tenía veintiséis), y aún recuerdo con toda nitidez mis temores sinceros ante su puerta, vencidos solo por la ilusión que se acrecentaba ante la inminencia de disfrutar de lo que yo sentía y sentiré siempre como un privilegio.

En uno de los cuartos que utilizaba para trabajar, dentro de aquella casa tomada en toda su extensión por los libros, Don Alberto me hizo sentir la pequeñez de mi naturaleza de alevín de cervantista al disponer ante mis ojos alucinados, en poco más de una hora, decenas de libros y artículos, perfecta y detalladamente reseñados uno a uno, que traía diligente a la mesa en donde yo le esperaba, mientras que él entraba y salía con exactitud en las diferentes estancias de su casa, en donde encontraba, en el sitio que él sabía exacto, los títulos que servían a un mismo tiempo para orientar mis pesquisas y para evidenciar, por si aún no lo tenía suficientemente claro, cuantísimo me quedaba por hacer. Esa misma pequeñez rayó en algo próximo al estupor cuando Don Alberto, que oficiaba solo para mí aquel rito iniciático en cuyo transcurso confirmé mi voluntad de abrazar el culto e ingresar en la secta, me preguntó, con la misma naturalidad que empleaba para enterrarme bajo los libros que iba trayendo, si yo leía ruso. Después de toda la atención y toda la energía que el maestro me estaba dedicando, confieso que me sentí de verdad culpable al tener que reconocer en voz muy baja que, si bien me manejaba 
en otras lenguas, entre otras muchas habilidades precisamente me faltaba -y me sigue faltando ahora, cumple reconocerlo honradamente- la de poder leer en ruso. Sin embargo, él, incansable e irreducible, me resumió allí mismo el contenido del artículo, posando de vez en cuando sus ojos en el texto mientras yo reaccionaba ante aquel alarde con la misma gallardía que podría haber mostrado la fiel máquina de escribir de mi anfitrión, que ocupaba un lugar preferente en aquel altar.

Aquel hombre incomparable, lector perspicaz de Cervantes, me hizo después otras muchas mercedes, tan importantes y valiosas para mí como su presencia en el tribunal de mi tesis doctoral o su aceptación cariñosa de la invitación que le hice para que prologase mi libro La ficción autorial en el Quijote y en sus continuaciones e imitaciones, en cuya presentación también estuvo a mi lado. Hoy, de nuevo afectado por su entrañable recuerdo, que siempre me acompaña, vuelvo a suscribir la absoluta certeza de que lo poco que yo pueda decir sobre Don Alberto no va a acrecentar ni un punto su condición ejemplar de hombre ilustre, sabio y bueno, limitación evidente que deja bien claro que la principal razón de mis palabras es el cariño del amigo y la admiración del discípulo.

Esas fueron, desde luego, las razones que guiaron mi primera respuesta a sus atenciones cuando, poco después, participé en el volumen del homenaje que, bajo la coordinación de Luciano García Lorenzo, le rindió la revista Anales Cervantinos en los años 1987-1988. Fue el mismo Don Alberto el que esa misma mañana de nuestro primer encuentro me invitó a publicar un artículo sobre mis investigaciones en la revista que él dirigía, y para dejar aún más claras, si cabe, su discreción y su grandeza, me advirtió expresamente de que el próximo número se iba a editar en su homenaje, para que yo me sintiera totalmente libre de publicar más adelante mi trabajo sin sentirme condicionado por circunstancias tan personales y significativas para él. ¿Cabe mayor muestra de mesura? No hace falta que aclare que lo que para él era un motivo de pudorosa reserva, para mí se convirtió en una razón añadida para que mi primera aportación sobre Cervantes se publicase precisamente en el número doble que le iba a ser dedicado.

\section{«Buen lector» (Quijote, I, 45); lector muy ocupado (a diferencia del «desocupado lector» del prólogo del Quijote de 1605)}

Sé de pocas personas que hayan conocido la obra cervantina, y muy particularmente el Quijote, tan profundamente como Alberto Sánchez, pero debo y quiero decir que conozco aún a menos personas que, como él, han sido capaces de ennoblecer una erudición ya no usada con el valioso y aún menos usado adorno de la humildad y la sencillez, virtudes que engrandecen su legado. Si su labor investigadora, impagable, nos ha dado un dominio privilegiado de las obras de Cervantes, su incansable tarea bibliográfica nos ha facilitado completísimas y reveladoras lecturas de esas obras. Véase si no su completa «Bibliografía cervantina», sección de Anales Cervantinos que sos- 
tuvo tantos años, mientras le asistió una salud que a pesar de su fragilidad tardó en minar su tenacidad y sus fuerzas. Don Alberto ha sido quien más y mejor que nadie hasta ahora, creo, ha sido capaz de reconocer, poner en valor y sistematizar con dedicación y pericia las raras especies de lo que él, muy acertadamente, denominaba «polícroma y variada floresta bibliográfica cervantina», y los cervantistas de todo el mundo le debemos sugerencias y noticias solo justificables a la luz del trabajo constante y eficaz de un lector permanentemente ocupado por el bien de nuestra causa.

Recuerdo con enorme afecto las intervenciones en varios idiomas de Alberto Sánchez, a quien el inolvidable José María Casasayas llamaba almus pater de la Asociación de Cervantistas, en los actos institucionales de los coloquios internacionales de Alcalá de Henares, y recuerdo de una forma muy especial su intervención en la conferencia inaugural del Coloquio Internacional «Perspectivas en los estudios cervantinos», que se convocó precisamente en homenaje a José María Casasayas en Argamasilla de Alba en noviembre de 1995. Aún conservo la imagen de aquel hombre al mismo tiempo enorme y menudo, cada vez más fatigado por su corazón enfermo, que cautivaba a la audiencia con su discurso seguro, fluido y muy bien trabado y su ademán retórico, signos magistrales de una escuela que parece destinada a desaparecer sin remedio: una escuela de sabios ocupados en el saber y preocupados por el saber cuya herencia es urgente mantener y reivindicar en todo momento.

\section{«Lector suave» (Quijote, I, Prólogo); «lector prudente» (Quijote, II, 24); «lector amable» (Quijote, II, 44)}

Reconozco en mi maestro Alberto Sánchez la amabilidad en el trato, la suavidad en la corrección y la prudencia en el consejo, complementadas por el estimulante vigor de su ejemplo. Encarezco la cordialidad con la que orientó siempre a todos los que un día nos acogimos a su generoso abrigo para intentar aprender de él lo que sabía y su forma de enseñarlo, siempre lejos de cualquier forma de presunción. Nunca podré olvidar la lección humilde que me dio un día aquel hombre que, desde su magistral amistad, se despidió de mí en una de sus cartas refiriéndose a sí mismo como «mi lector». Así, con ese tratamiento excesivo y abrumador, me desveló sin saberlo, una vez más, la desoladora vastedad de mi ignorancia frente al pozo de sabiduría que de él manaba. Entonces supe, también una vez más, en qué consistía la inconfundible diferencia entre un hombre sabio y dulce y tantos otros profesores que un día tuve, hombres y mujeres mediocres que alguna vez, casi a beneficio de inventario, me dispensaron con cuentagotas y hasta con displicencia las píldoras de su conocimiento desde un pedestal de soberbia y superioridad indisimuladas, y esta lección fue una de las mejores que nadie pudo darme en mi carrera vocacional de profesor y de investigador.

Ojalá yo pueda algún día dominar el secreto que ocultaban aquellas palabras humildes, pero de momento, y aunque ya tenía muy claro el perfil de profesor al que yo quería adscribirme, supe con paladina certeza que Alberto 
Sánchez pertenecía con ventaja a ese modelo. Para persistir en ese objetivo, siempre me ayudó y me ayudará releer sus cartas, que conservo en mi archivo desde la primera a la última, igual que conservo en la pared de mi despacho, entre tantos otros recuerdos, aquella reproducción de Hall Barnell que me regaló cuando defendí mi tesis, en la que Avellaneda copiaba de Cervantes mirando por encima de su hombro, mientras Cervantes hacía lo propio con mi particular enemigo Cide Hamete Benengeli. Y es que don Alberto ha llevado el cervantismo hasta el difícil arte del regalo. Eso fue para mí conocerle y tratarle, un enorme regalo y un gran privilegio del que soy consciente con toda la gratitud que puede profesar quien, como yo, está seguro de que la gran humanidad de Alberto Sánchez tendrá siempre la fuerza y la vigencia que mantuvo en su vida, ejemplo fecundo de cordialidad y de sabiduría.

\section{«Lector carísimo» (Quijote, I, Prólogo); «lector amigo» (Quijote, II, Prólogo)}

Hoy, en este volumen de Anales Cervantinos dedicado a los veinticinco primeros años de la Asociación de Cervantistas, que vi nacer con los ojos admirados del joven que fui un día y que he visto crecer al compás de mi propia madurez, me honro en evocar a Don Alberto, presidente fundador, con gratitud y cariño, y vuelvo con honda nostalgia sobre algunas de las palabras que pronuncié el 8 de febrero de 1999 en el homenaje que, ya anciano y con un hilo de voz que aún atesoraba un cordial entusiasmo, le dedicamos sus colegas, discípulos y amigos en la antigua sede en Madrid de Middlebury College, prestigiosa institución académica estadounidense en la que asumí la responsabilidad de sustituirle durante dos años tras su retiro y en la que Don Alberto recibió la acogida que, como tantísimas veces ha ocurrido y ocurrirá, no supo o no quiso dispensarle la universidad española. Recuerdo esa tarde soleada de invierno a Alberto Sánchez celebrando cada intervención y pronunciando con emoción el nombre de todos los que participamos en aquel acto. Me duele también recordar que a partir de entonces, hasta su muerte en 2003, Don Alberto fue decayendo invierno tras invierno.

No es en absoluto casual que este ejercicio de recuperación histórica en el que se publican estas palabras cargadas de afecto vaya a publicarse coincidiendo con el cuarto centenario de la publicación del Quijote de 1615, ni lo es tampoco que en 2015 se conmemore el centenario de Alberto Sánchez, cuya trayectoria vital, por razones ideológicas y familiares que ahora no vienen al caso, fue cualquier cosa menos cómoda y tranquila. Nada de eso supuso un lastre para su ejemplaridad ni para su vocación de servicio a este país que tanto le debe.

En 1997 le dediqué a Alberto Sánchez, al mismo tiempo que a otros dos grandes maestros y amigos, José María Casasayas y José Carlos de Torres, mi antología de máximas retóricas de Platón, Aristóteles, Cicerón y Quintiliano, un libro cuya temática se aleja del cervantismo. Solo me cabe reiterar, a tiempo de cerrar estas palabras, lo que entonces declaré: mi profunda admi- 
ración por Alberto Sánchez, maestro cordial en la palabra bien dicha y en el esfuerzo y el cariño que conducen al trabajo bien hecho.

\subsection{José María Casasayas ${ }^{19}$}

Son muchos los textos que se han escrito y publicado in memoriam de José María Casasayas, figura mayor de la creación de la Asociación de Cervantistas cuyos ya más de 25 años de intensa e ininterrumpida labor ahora se conmemoran.

Falleció el día 27 de setiembre de 2004, una muerte para la cual nos encontró a todos desprevenidos. Se preparaba para abrir las celebraciones del IV Centenario del Quijote, en Seúl (Corea), con un coloquio internacional que iba a tener lugar entre los días 17 y 20 de noviembre de ese año. A menos de dos meses, pues, de su realización. Estaba ilusionadísimo con este Coloquio y tenía la intención de dar una vuelta por Japón, aprovechando la cercanía. Ya había empezado a preparar rutas y a reservar hoteles, y contaba con la compañía de amigos y amigas que había invitado.

No pudo ir, la vida ya no se lo permitió. ¡Se tenía tan merecida esta alegría! Tampoco llegó a recoger aquella botella de buen vino blanco portugués que, unos días antes, yo le había dejado en ese hotel cerca de la Puerta del Sol, donde le gustaba alojarse cuando iba por Madrid, donde había estado hacía un par de semanas para seguir organizando el ambicioso calendario de celebraciones que había trazado para la Asociación en el IV Centenario de la publicación de nuestro Quijote.

En estos diez años que pasaron desde su muerte, mucho se ha escrito sobre su enorme labor como impulsor del cervantismo en España y en todo el mundo. También sobre su obra crítica y su personalidad. El sábado, 2 de octubre de 2004, José Montero Reguera, el joven Vicepresidente de la Asociación de Cervantistas quién vino, justamente a sucederle en la presidencia de la misma, tituló la nota necrológica en El País: «Hasta siempre, buen amigo». Y, en ella, escribía sin ambages: «a él se debe la creación y pervivencia de la Asociación de Cervantistas, que va camino de cumplir su mayoría de edad». Él era, como tiene el cuidado de señalar el amigo, con su nombre verdadero y completo, Josep Maria Casasayas i Truyols, mallorquín, de Palma, donde había nacido. Pero habríamos de conocerle con el nombre castellanizado y no le he oído nunca quejarse de ello. Su obra mayor que dejó terminada, tal como el Persiles de su adorado Miguel de Cervantes, solo sería publicada póstumamente, gracias al gran empeño de sus hijos: la traducción del Quijote a su lengua materna.

Que la vida es tantas veces muy injusta, bien lo sabemos. Aunque él, católico, creía o decía creer que todas las desgracias tenían su razón. ¡Injustísi-

19. Por Maria Fernanda de Abreu. 
mo, sin embargo, y una sinrazón, me sigue pareciendo que José María se haya muerto justo a menos de dos meses de poder participar y ver y disfrutar de todo un trabajo y dedicación de años en que había empeñado fuerzas y no poco peculio personal para homenajear a su Cervantes del alma! Pasados diez años, no, no hay, ni habrá cómo conformarse con ello. Y no hablo aquí de las saudades personales de un amigo entrañable y de un ser ejemplar en su afición, adición, cervantina. Pienso en todo lo que, en estos años, él se hubiera inventado para seguir extendiendo el estudio de la obra del escritor. Pienso también en su bastón en ristre contra entuertos y disparates que un día y otro día acechan a los estudios cervantinos.

No era, además, 1605, una fecha cuyas celebraciones se le hubieran ocurrido la víspera. En el Prólogo del tomo V de su Ensayo de una Guía de Bibliografía Cervantina. Ediciones castellanas del Quijote (1605-1915), que publicó «A costa del autor, en la ciudad de Mallorca», en el año de 1995, al justificar el haber empezado por este tomo V, escribió:

He empezado por el tomo $\mathrm{V}$ porque justamente su materia, junto con la del II, es la que tenía más avanzada, y limito el período hasta 1915 por la sencilla razón de que de 1915 acá la diarrea cervantino/quijotesca ha sido tal que requiere una segunda parte, mucho más voluminosa que la primera, y más si se quiere completar hasta el año 2005, en que se cumplirán los 400 años de la andadura de don Quijote y es, además, fecha que está al caer, así como avanza, tan de prisa, el tiempo. (Cursiva mía).

No esperábamos, no, que su muerte viniese antes de que llegara esa fecha. Pero todos y todas sabíamos que si queríamos seguir su ejemplo había que continuar su sueño. Y el joven Vicepresidente que, en la década siguiente honró cabalmente su proyecto, lo tuvo, ya entonces, bien claro pues que termina su nota, escrita «en horas de pesadumbre y de tristeza», con la siguiente apóstrofe: «José María nos ha legado una labor extraordinaria, ahora hay que continuar; de lo contrario, Casasayas nos regañaría: a trabajar».

Nos quedamos tan tristes que Alicia Villar Lecumberri y yo misma decidimos no ir ya a Seúl. A pesar de, o precisamente porque él nos había ya comprado nuestros billetes de avión, en recompensa del trabajo hecho por ambas en el Congreso del año anterior, en Lisboa. En aquel momento, no pudimos hacerlo, quizás debiéramos haber ido... Y es que allí mismo, en Seúl se le prestó el primer homenaje, en el ámbito cervantista. En su apertura, Chul Park, quien había organizado el Coloquio con Casasayas, expresó su desazón, que lo era de todos nosotros, a la vez que su gratitud:

A finales de septiembre de 2004, cuando nos encontrábamos preparando este Coloquio, se nos dio a conocer la trágica noticia del fallecimiento de nuestro querido amigo y presidente, J. M. Casasayas. Esta noticia había sido tan inesperada y repentina que ni nos había dejado hacemos a la idea de su pérdida, y tan solo pudimos despedimos de él con una modesta corona que el 30 de septiembre enviamos al Tanatorio del Cementerio Municipal de Palma de Mallorca. Lo que nos había quedado de él era su ilusión 
por celebrar el XI-CIAC en Seúl, en un país lejano del Extremo Oriente, y los esfuerzos que había invertido a lo largo del año 2004 para conseguirlo. Por nuestra parte, lo que nosotros podíamos hacer en su memoria, sin duda, era seguir con esa ilusión y llevar a cabo este XI-CIAC con gran éxito, en señal de aprecio y despedida de nuestro amigo y líder eterno. Como él, nosotros también soñábamos con este XI-CIAC, siendo la primera ocasión en que se celebraba en el continente asiático.

Y en el texto «In memoriam José María Casasayas» recuerda los «muchos momentos de amistad que su generosidad, tan desinteresada como entrañable, ha sabido siempre dispensar a todos los que nos hemos acercado, en su momento, a aprender de su entusiasmo y de esa pasión suya por el cervantismo».

Sé bien de esta pasión, entusiasmo y capacidad suyos, de los que habla aquí nuestro colega coreano, para llevarnos a hacer lo que uno no se hubiera imaginado jamás posible. Cuando me desafió a hacer el Congreso en Lisboa en 2003, el último antes de las celebraciones del IV Centenario del Quijote y, por eso, sobre El Persiles, me quedé de piedra. Sus sueños de cervantismo eran, o le parecían quizás a muchos, delirantemente quijotescos. Pero la verdad es que, gracias a José María, a nosotros, los que hemos seguido sus sueños, las cosas nos han ido mucho mejor que a Alonso Quijano. Quizás porque Casasayas tenía en sí a ambos, a Quijote y a Sancho, y sacaba de uno o de otro según los anhelos y las piedras y tropiezos de los caminos.

Recuerdo siempre, y ello me sirve de ejemplo, como acariñaba y estimulaba a los investigadores acabados de llegar al cervantismo, muy jóvenes algunos y algunas, otras veces ya no tan jóvenes. Con ya dos décadas de estudios franceses, comparatistas o de la narrativa de los siglos XVIII y XX, como era mi caso, sé bien que nunca yo hubiera seguido este camino de no haber sido por el apoyo, la confianza y el ejemplo de Casasayas. Además, al invitarnos a los primeros, y para mí, inolvidables encuentros de Alcalá de Henares, nos inculcaba el vicio... De no haber sido así, no hubiera yo conocido a quienes, después, han sido mis maestros, como Francisco Márquez Villanueva, Avalle-Arce, Agustín Redondo, Anthony Close, Carlos Romero, Aurora Egido y Carlos Alvar. ¡Qué sabiamente trataba José María con las tan diferentes personalidades de cada uno!

En 2005, todos los coloquios y congresos programados por él fueron, qué pena y qué triste, en su homenaje o in memoriam. También otros, que se hicieron por ciudades del mundo. Y, publicado ese mismo año, el número correspondiente al otoño de 2004 de la Revista Cervantes, Bulletin of the Cervantes Society of America, vol. XXIV, n. ${ }^{\circ}$ 2, dirigida por D. Eisenberg, contenía ya cerca de 200 páginas de Homenaje a José María Casasayas. Registro los diferentes artículos porque su lectura, de todos y cada uno, me parece fundamental para conocer la labor cervantista de nuestro Presidente. Escritos con ese sentimiento fundamental que les unía a sus autores con $\mathrm{Ca}-$ sasayas pero también por eso mismo y, en nombre de esa amistad (¿tema mayor del Quijote, verdad?), con el rigor y la dedicación que exigen trabajo 
y sensibilidad. Así: Helena Percas de Ponseti, «Adiós a José María Casasayas»; Daniel Eisenberg, «Recuerdos de Pepe»; Santiago López Navia, «Ithaca semper incognita. José María Casasayas, cervantista»; Daniel Eisenberg, Santiago López Navia, y José Montero Reguera, «Escritos de José María Casasayas. Coloquios y congresos de la Asociación de Cervantistas». Y una perla: «Pequeña antología de José María Casasayas», que reproducen algunos textos suyos. Mucho se siguió escribiendo pero este me parece un dossier indispensable para quienes quieren conocer la obra y el hombre.

Hay quienes lo consideraban un «duro» e intolerante. Daniel Eisenberg, en el referido texto, retrata bien en qué consistía su dureza: «Pepe era intolerante con la informalidad, la incompetencia y la pereza, de la gente que pudo haber hecho algo bien y lo hicieron mal». Yo recordaré siempre su inmensa ternura: por su tierra, por su lengua mallorquina, por su familia, por sus amigos. Y por el pobre de Alonso Quijano, obligado a inventarse una máscara para poder ser más feliz e intentar curar su inmensa melancolía. Recordaré siempre los ojos de Casasayas, aguados de emoción al escucharme leer el poema de Miguel Torga «Exhortación a Sancho», del libro Poemas Ibéricos (en traducción de Pilar Vázquez Cuesta, omitiendo la estrofa tercera). Aquí lo repito, segura de que a él le gustaría escucharlo de nuevo:

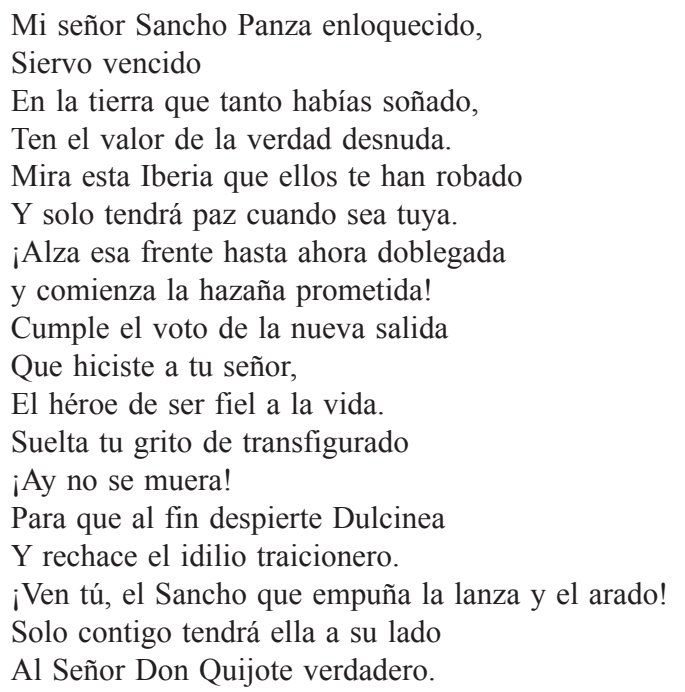

Otras caras de esa riquísima sensibilidad que lo había convertido en uno de los mejores lectores de Cervantes eran su amor y respeto por la naturaleza y la vida (fue fundador y el primer presidente del Grup Balear d'Ornitologia i Defensa de la Naturalesa) y su pasión por la música, que tenía un lugar importantísimo en su vida. Daniel Eisenberg lo refiere con estas palabras: «Era también amante de la música, sobre todo de la ópera; llevaba consigo siempre una lista de las grabaciones que poseía, por si en alguna tienda diera con una desconocida. Se desplazó para ver ópera: a EE.UU. para ver, en Flagstaff 
donde nosotros, una representación del Anillo de Wagner. No se quería perder ninguna».

Era, sin duda, la ópera una de sus pasiones. Y Wagner, por encima de todos los demás. Más de una vez fue al Festival de Bayreuth, para emborracharse de Wagner, e invitaba a amigos a que lo acompañasen. Pero no siempre lo conseguía. Entendía que a una de sus amigas, estudiosa del romanticismo melodramático y del folletín, además del Quijote, le gustase la ópera de Verdi pero, con una sonrisa tolerante y socarronamente irónica, dejaba bien claro dónde, para él, y para la historia de la ópera, estaban el uno y el otro. Pero esta amiga se vengaba porque el folletín de sus gustos musicales era, al fin, el fado. Tenía una discoteca de fados como no he conocido desde luego a ningun no portugués. Se conocía las pequeñas tiendas de Lisboa donde buscar sus fados, alguna de ellas sin letrero en la puerta, un cubículo mal amañado, al fondo de una estrecha escalera de un segundo piso. Y los buscaba, y encontraba, deambulando solo por las calles y a pesar de sus dificultades para hablar después que esa otra maldad de la vida le obligó a una laringotomía. También para estos venía con su lista (por lo menos cuando venía a Lisboa). Pero, la verdad es que no se trataba de una lista hecha de cualquier manera. José María no hacía nada de cualquier manera. Como buen coleccionista, era obsesivamente ordenado y la «lista» era un pequeño cuaderno. Sus «listas», de óperas o de fados, y supongo que de muchas otras cosas (¿sus relojes de pared?), estaban hechas con el mismo rigor con el que había hecho su referido Ensayo de una Guía de Bibliografía Cervantina. Y también aquí, siempre en el mismo Prólogo, podemos entender las razones de ellas, cuando nos dice:

Y le he dado el tamaño con que lo presento a fin de que quepa en un bolsillo de americana cualquiera cuando uno sale de pesquisa por librerías de lance, como el de estas guías de ciudades o países que conviene llevar encima, cuando nos vamos a tierras lejanas, para no perdernos, o para poder encontrar el museo de antropología (si lo que uno busca es el museo de antropología, claro, no si busca el teatro de la ópera), o para saber a dónde se halla la oficina de objetos extraviados. Por si acaso...

(Seguro que José María Casasayas ya tenía preparadas sus listas para Corea y Japón...). Un día me envió una cassette con las varias interpretaciones que la grande Amália, en diferentes épocas de su vida, había grabado de ese impresionante poema de Alexandre O’Neil, con música de Alain Oulman, Gaivota. Y él lo sabía de memoria. Entendía perfectamente los fados en portugués: su lengua mallorquina, el castellano, el francés y sus estudios de latín, además de la atención y dedicación y sensibilidad, le bastaban. También esta atención a los más diversos aspectos de la vida, a no querer perder de vista nada de su riqueza y complejidad era, en él, una actitud pareja a la de Cervantes, esa que tiene en el Quijote el más fulgurante testimonio. Junto a una fidelidad, a la vez programática y visceral, a la imaginación y al sueño, José María Casasayas tenía una cultura literaria y artística, en general, impresionante. Su admiración por la obra de Cervantes se servía de ella. Da cabales 
pruebas de eso mismo en su defensa de la locura. Termino, pues, quiero terminar, con sus palabras, de cuya memoria siempre sacaré provecho:

Me refiero a Séneca, coetáneo de Jesucristo, en De vida beata: «Todos los hombres, Galión hermano, quieren felizmente vivir, pero para barruntar lo que hace bienaventurada la vida, andan a ciegas.» ¡Andan a ciegas! Todos andamos a ciegas porque no podemos conformarnos con la aparente sensación de bienestar que nos proporciona el ejemplo de los demás mortales porque no es más que un síntoma de nuestra cobardía: si nos conformamos con el falso Beatus ille horaciano, vemos que llegamos a la peor de las esclavitudes, cual es la negación de nuestra propia personalidad, y entonces, en nuestra desesperada búsqueda de la felicidad no siempre acertamos, como dice Séneca, porque, además, Jedes Neue, such das Glück, erschrekt! Y perdonadme que lo diga en el alemán original de Schiller porque no tiene desperdicio: «Todo lo nuevo, incluso la felicidad, causa espanto». De aquí, señoras y señores del Jurado, que el que se atreve a buscar la felicidad por el único camino posible, que, como nos ha demostrado el Sr. Castilla del Pino, es el de oponerse, por medio de lo que hemos dado en llamar locura, al mundo circundante para ver realizar nuestro fin para [el que] creemos haber nacido (sea para limpiar el mundo de sus injusticias, como don Quijote, sea para equilibrar a los desequilibrados, como el propio Sr. Castilla del Pino) y afirmar, así, nuestro propio «ser» (no nuestra existencia). [...] Téngase en cuenta que «La felicidad no es un ideal de la razón, sino de la imaginación» (son palabras de Kant, 1724-1804) y que no es la razón lo que hace grandes a los héroes, sino su imaginación. ¿Qué sería de la Mancha razonable sin la Mancha imaginativa? Si echaseis mano de vuestro raciocinio, ¿estarías aquí vosotras, vosotros, todos, defendiendo verdades como templos que, empero, parecen fantasías como catedrales? Si la felicidad consiste en llegar a afirmarse plenamente en su propia esencia para lo cual cree uno haber nacido, y solo hay un medio plausible de llegar a ella, que es mediante la locura, entendida como desvío voluntario de la torpe realidad cotidiana, entonces bendigamos esta locura. El que se la procura es que no ha sentido el espanto que pregona Schiller: ha sido un valiente, tanto más cuanto más cruel resulte luego su experiencia, como un don Quijote caído, molido, apaleado y burlado. Porque el tal siempre será consciente, como el mismo don Quijote, de saberse quién es en todo momento.

\section{PASADO Y PRESENTE}

\subsection{Imágenes del cervantismo actual: bosquejo de una lectura de las Actas de los Congresos Internacionales de la Asociación de Cervantistas (1995-2014) 20}

Desde su fundación en el salón de sesiones del Ayuntamiento de Alcalá de Henares el ocho de abril de 1988, la Asociación de Cervantistas ha venido

20. Por Isabel Lozano-Renieblas. 
celebrando reuniones, congresos y coloquios internacionales periódicos con el fin de promover la investigación sobre Miguel de Cervantes y su obra. Su primera Junta Directiva, presidida por Alberto Sánchez y con José María Casasayas como vicepresidente, convocó el 29 de noviembre de ese mismo año el primer Coloquio Internacional celebrado en Alcalá de Henares. ${ }^{21}$ Tres años después, en 1991, se celebraba en Almagro el Primer Congreso Internacional de la Asociación de Cervantistas. A él le siguieron siete más hasta la fecha: Nápoles (1994), Menorca (1997), Lepanto (2000), Lisboa (2003), Alcalá de Henares (2006), Münster (2009) y Oviedo (2012). Excepto del Congreso de Almagro, del que no se publicaron actas, aunque se distribuyeron en el propio congreso los resúmenes de las 142 ponencias no plenarias expuestas, de los siete restantes se han editado las actas correspondientes. Historiarlas entraña un reto y un riesgo. Por una parte, no es posible leer con detenimiento la totalidad del material. Por otra, no se pueden extraer sino conclusiones parciales, pues las reuniones convocadas por la Asociación de Cervantistas son solo una parte de la investigación sobre Cervantes. Me contentaré, y en esto apelo a la generosidad del lector para los errores y a la disculpa para las omisiones, con esbozar el recorrido que traza la investigación sobre Cervantes en estos veinticinco años.

Aun a sabiendas de que un material parcial solo puede arrojar resultados provisionales, pueden anticiparse algunos rasgos que apuntan en la dirección hacia la que se encaminan los estudios cervantinos. Se puede apreciar un crecimiento de la periferia frente a la atrofia del centro, que se manifiesta en una doble dirección. Me explicaré. Mientras que la crítica de las obras que gozaron de mayor popularidad, esto es Novelas ejemplares y Quijote, no está atravesando su mejor momento, es más, podría decirse que está sumida en el estancamiento que marca la continuidad con líneas de investigación bien asentadas, aquellas que habían tenido una atención deficiente, como El Persiles, el teatro o la poesía, están experimentando un relanzamiento desigual pero importante, con propuestas de lectura novedosas, en el teatro o en la lírica, o radicalmente diferentes, en El Persiles. Por otra, este crecimiento de los márgenes no se contiene en los límites de las preferencias por unas obras u otras. En el Quijote el apartado dedicado a la recepción e influencias ha ido creciendo de manera desmesurada, sobre todo en el último congreso, pero ello no se ha traducido en una renovación de los acercamientos críticos. A este fenómeno se suma otro igualmente significativo: la renuncia a las interpretaciones de conjunto. El estudio del Quijote se aborda desde planteamientos parciales. Los objetivos de la crítica persiguen estudiar un personaje en con-

21. Remito a <http://cvc.cervantes.es/literatura/cervantistas/default.htm>, donde el lector puede consultar no solo la historia de la Asociación, sino también un catálogo completo de sus publicaciones hasta el momento. No están incluidas las Actas del VIII Congreso Internacional, celebrado en Oviedo del 11 al 15 de junio de 2012. Agradezco a su editor, Emilio Martínez Mata, la gentileza de haberme hecho llegar una versión electrónica de las Actas del VIII CINDAC para la preparación de este trabajo. Por comodidad para el lector, en esta sección se emplearán las abreviaturas $C I A C$ y $C I N D A C$ para referirse respectivamente a los coloquios y congresos internacionales de la AC. 
creto, una determinada técnica literaria o un tema focalizado. Suele justificarse esta elección argumentando que la bibliografía resulta inabarcable e imposibilita llevar a buen término cualquier estudio que se proponga un acercamiento global. Pero quizás sería más exacto explicar esta renuncia como el agotamiento de los métodos de investigación al uso, en especial el de la Escuela de Filología Española, y la dificultad de la crítica para encontrar el camino hacia una historia literaria dotada de recursos de mayor calado. De ahí la sensación colectiva de embotamiento debido a la inflación crítica; y de ahí también que, ante la dificultad de encontrar parcelas libres de las adherencias críticas, se busque ese espacio subsidiario, bien sea en las influencias de personas, tiempos y lugares bien en la materialidad del texto, concediendo importancia a temas menores a falta de otros de mayor enjundia. Así puede entenderse la importancia que ha cobrado en los últimos años el debate sobre la configuración no ya de la obra sino de la misma página del libro. Y algo parecido podría decirse de los acercamientos que se han ofrecido desde el neohistoricismo culturalista.

Para llevar a cabo esta tarea he organizado el material atendiendo a las singularidades críticas de cada una de las obras de Cervantes con el añadido de una obligada sección biográfica. Las celebraciones del II y IV Congreso Internacional de la Asociación de Cervantistas tuvieron como escenario dos ciudades emblemáticas en la biografía cervantina: Nápoles y la ciudad de Naupaktos, frente al golfo de Lepanto. La vinculación cervantina con Nápoles se manifestó en un reiterado deseo de volver tras su alistamiento en la marina en 1570 y su breve estancia en la ciudad después de recuperarse en Mesina de las heridas recibidas en Lepanto. El recuerdo y homenaje del autor del Viaje del Parnaso a Nápoles adquiere forma literaria en la imagen de Parténope sentada a la orilla del mar (Cirillo, 1995), a la vez que ese regreso frustrado se manifiesta en un proyecto trunco que debía servir de celebración de la vuelta que nunca se produjo (Sansone, 1995). Lepanto necesariamente habría de propiciar una reflexión, pues, como decía Pirandello, detrás de los molinos de viento está siempre la batalla de Lepanto, y no solo por su impacto histórico (Campos y Fernández de Sevilla, 2001), sino también por el poso que dejó en su escritura el dolor físico y el cautiverio argelino (Ricapito, 2001; Abi-Ayad, 1995). La omnipresencia de Lepanto en el imaginario cervantino corre pareja a la necesidad autorial de no contaminar la imagen mítica con lo cotidiano (Gaylord, 2001), que se sustituye por imágenes alegóricas (Parodi de Geltman, 2001). Cabe mencionar en este apartado el sugerente trabajo de Sarantis Antiochos sobre un posible conocimiento entre el Greco y Cervantes. Antiochos (2001) formula la hipótesis de que a través del matrimonio con Catalina pueden rastrearse puntos de contacto entre ambos artistas. Y aunque Antiochos sostiene que el cuadro pintado por el Greco que se conserva en el Metropolitan Museum de Nueva York es del Cardenal Bernardo de Sandoval y Rojas, Arzobispo de Toledo y protector de Cervantes, y no del Cardenal Niño de Guevara, en nada invalidaría su hipótesis que fuera este último. Siempre me ha llamado la atención la relación del cardenal Niño de Guevara 
con el mundo del arte y de la cultura, y acaso no sea una coincidencia que fuera pintado por el Greco y, al mismo tiempo, el destinatario de algunas Novelas ejemplares; unas de forma implícita, como el Rinconete y el Celoso extremeño del manuscrito Porras de la Cámara; otras, indirectamente, como el señor arzobispo, para quien los eclesiásticos de La española inglesa piden que se ponga por escrito. Pero la biografía cervantina da para mucho y abarca otros aspectos que han despertado el interés de la crítica, como son el cruce entre ficción y documento de la información en Argel ante fray Juan Gil (Piras, 2001), la «supuesta hidalguía» de Rodrigo o el «heroísmo» de Miguel (Sliwa, 2001 y Rossi, 1998). Sin embargo, más allá de artículos sugerentes y bien trabajados como el de Antiochos, no hay avances significativos en los acercamientos a la biografía cervantina. Esperemos que nuevos hallazgos, como los cuatro documentos sobre la estancia de Cervantes en Andalucía, descubiertos recientemente por José Cabello, archivero de la Puebla de Cazalla, permitan desterrar los mitos y despejar las incógnitas que todavía anidan en la biografía cervantina.

\section{La Galatea}

La Galatea acaso sea la obra que sufre un mayor desgaste con el paso del tiempo, a pesar de que cuenta con un público constante aunque minoritario. La línea predominante en la celebración del cuarto centenario de la publicación de La Galatea se centró en el tratamiento de la verosimilitud y en las novedades experimentales (Romanos, 1995). Diez años después, se trataba de hilvanar los puntos de sutura más que de ruptura con la pastoril. Así la ampliación del modelo genérico fijado por La Diana que Cervantes lleva a cabo en La Galatea ocupa un lugar destacado en la evolución del género, al compatibilizar el canon pastoril con nuevas perspectivas narrativas (Romanos, 1995). En esta misma línea se sitúan las soluciones que adopta Cervantes ante el problema religioso en la pastoril (Márquez Villanueva, 1995) o el homenaje a Garcilaso en el final de La Galatea (Vila, 1995). La relación con el neoplatonismo, con los temas órficos, con la égloga o la función del referente bíblico se cuentan entre los temas que buscan restaurar las líneas de continuidad con el género pastoril (Rosucci, 1995; Honda, 1995 y Fine, 2008).

\section{Teatro}

El interés por el teatro, en cambio, se manifiesta no solo en términos cuantitativos sino en una variedad temática de hondo calado, que supone una renovación de las perspectivas críticas. La obra dramática cervantina se ha debatido entre ser encasillada en el clasicismo y la subordinación al éxito de la fórmula lopesca expresada en la comedia nueva, y solo en tiempos recientes se ha valorado por sí misma. El estudio liberado del peso de ambos presupuestos revela que Cervantes tenía una propuesta teatral novedosa y en cierta forma experimental, con una mano tendida hacia la comedia nueva pero 
cuestionando, con la otra, algunas de sus soluciones, sobre todo, en las comedias y entremeses (González, 2001), pues, como ha apuntado González Maestro, el teatro cervantino no se aviene bien con la puntual observancia de los principios del clasicismo (Sabik, 2001). El estudio del espacio teatral arroja resultados especialmente fructíferos, pues en las comedias cervantinas hallamos una multiplicidad espacial que describe una amplia gama de matizaciones que va desde los espacios dobles y triples en El gallardo español al espacio fantástico y de tramoya de La casa de los celos (González, 2014 y 2011). Esta construcción espacial, vinculada al género o subgénero teatral correspondiente, no solo permite comprender en profundidad el funcionamiento de la obra como espectáculo, sino que apunta hacia una nueva propuesta en la concepción dramática (Rubiera, 2001 y González, 2011). Dentro de la variedad de recursos escénicos que integra esta propuesta novedosa, además de la introducción de «figuras morales» para representar los pensamientos de los personajes, como reivindica el prólogo de las Ocho comedias, no debe soslayarse la importancia que adquieren las acotaciones escénicas como apoyo a la tensión dramática (González, 1995 y 1998; Andrés, 1998). A pesar de que la preferencia del público de entonces y de los lectores de hoy se inclina hacia el proyecto de Lope, Cervantes muestra en su obra el atinado oficio de poeta y dramaturgo, que lejos de ceñirse a los parámetros al uso del teatro áureo se presenta como un artista escrupuloso de amplios horizontes estéticos, como puede observarse en La casa de los celos (Brito Díaz, 1998; Sabik, 2004 y González, 2014). Acaso haya sido esta última la obra de más difícil recepción y solo recientemente se ha revisado el tópico de obra apresurada y se ha valorado su composición híbrida, donde conviven sin fisuras personajes del ciclo carolingio, pasados por el filtro de Boiardo y Ariosto (Romera Pintor, 2001), con personajes pastoriles y figuras mitológicas y alegóricas (González, 2014). Completan las contribuciones al estudio de las comedias, el tratamiento cervantino del martirio en El trato de Argel y Los baños de Argel (Hutchinson, 2014), la configuración del héroe fronterizo en El gallardo español (Carrasco Urgoiti, 1998), las fuentes bíblicas en La gran Sultana (Fine, 2004), el lenguaje de germanía como posible mensaje a Avellaneda o la figura de Escarramán en El rufián viudo (Nishida, 2008 y Rodríguez Mansilla 2011).

En el caso de La Numancia sucede algo parecido. No hay consenso crítico ni en cuanto a la filiación genérica ni en cuanto al sentido del personaje principal, lo que ha afectado de manera profunda a su interpretación. Como tantas veces ocurre con Cervantes, las lecturas, a veces dispares, van desde el encomio imperialista, que tiende a revisarse, hasta el más actual sentido antifelipista o el cuestionamiento del imperio (Aladro, 2014). La ambigüedad se erige en una de las señas de identidad de La Numancia y, ante ella, no faltan las llamadas a la cautela, calificándola de poema mixto (dramático y diegético) (Lauer, 2014), orientado hacia la creación de la conciencia nacional, cuyo fundamento último se asienta en la noción de lo colectivo (Endress, 2014). Dentro del capítulo de las influencias, Canavaggio (1998) parte de La Numancia para ilustrar la herencia del teatro de Séneca en la España de Felipe II. 
Tras analizar la secuencia de la escena segunda, en la que los sacerdotes de la ciudad ofrecen un sacrificio a los dioses después de la negativa de Escipión a aceptar la propuesta de los jefes arévacos, llega a la conclusión de que la fuente no puede ser sino Séneca, porque Cervantes articula sacrificio y conjuro, precisamente como en el Edipo. Sin dejar el terreno de las influencias, González Maestro (2001) reflexiona sobre la poética de lo trágico en el teatro de Cervantes y su repercusión en la obra de Georg Büchner siguiendo la estela que el romanticismo alemán dejó de su lectura de La Numancia.

Las aportaciones sobre los Entremeses, mucho más modestas, se limitan a una temática bien conocida, como es el carácter negativo del matrimonio, las modalidades de expresión dialogal o en la interpretación de la parte VIII de las comedias de Lope de Vega como un homenaje satírico a Cervantes (Rolfes, 2014; González Maestro, 1998 e Inamoto, 1995). Por último, aunque de interés minoritario, la necesidad de fijar el corpus cervantino (obras teatrales, poesía, novelas o, incluso, obras de interés histórico) ha sido preocupación reiterada de ilustres cervantistas. Son dos las atribuciones cervantinas revisadas en estos congresos: La soberana Virgen de Guadalupe, y sus milagros, y grandeças de España y La tía fingida, tantas veces atribuida y otras tantas negada. Sobre la primera, Montero Reguera (1998), buen conocedor del tema, concluye que los argumentos a favor de tal atribución son demasiado endebles para incluirla en el canon cervantino mientras que Kenji Inamoto (2004), aunque no llega a conclusiones definitivas, parece inclinarse a favor de negar la atribución de La tía fingida.

\section{Lírica}

La poesía es otro de los géneros a la espera de que la crítica se libere del pesado fardo de las comparaciones, unas veces con egregios poetas contemporáneos, otras con la misma prosa cervantina, y de que se le dedique el espacio que amerita. Y si es verdad que en los últimos tiempos ha crecido el interés por la poesía no lo es menos que, a pesar de que su autor tenía el «arte/ dulce de la agradable poesía» en la más alta consideración, la crítica sigue percibiéndola como «problemática», sobre todo, porque uno de los rasgos que singulariza la poesía cervantina es el hecho de que buena parte de ella se halla inserta en un marco de enunciación narrativa, inseparable de la función del propio verso. Este rasgo tiende a verse no tanto como una tacha cuanto un logro emparentado con la modernidad (Romo, 2001; Nishida, 2008 y Mata Induráin, 2004). Los motivos emblemáticos de la poética cervantina, la tipología del hipérbaton que proponen Antonio Bernat Vistarini (1995) y GarcíaPage (1995), o el análisis de géneros como el del epitafio, analizado por Montero Reguera (2011), quien traza el corpus textual de los epitafios cervantinos deteniéndose en los dedicados a Isabel de Valois y a Fernando de Herrera, son testigos de esta revisión necesaria de uno de los territorios menos explorados de la estética cervantina. 
Especial atención merece el Viaje del Parnaso, sobre todo, por el protagonismo que tuvo en el Congreso de Nápoles, como he señalado anteriormente. Uno de los polos en torno a los cuales ha girado la crítica del poema tiene que ver con la biografía de su autor, en la medida en que reivindica el lugar que a Cervantes le corresponde en las letras españolas (Profeti, 2001). Un segundo aspecto estrechamente vinculado a la biografía del autor tiene que ver con el uso de la ironía, que diluye tanto las dudas personales como el menosprecio ajeno a la poesía cervantina (Gutiérrez, 2001). Fruto de este reverdecer del interés por la poesía es el trabajo llevado a cabo por el grupo de investigación coordinado por José Montero Reguera desde la Universidad de Vigo, que expuso en el panel dedicado al tema un ambicioso proyecto sobre la poesía cervantina (Montero Reguera, 2014). Se propone fijar el canon poético cervantino y elaborar una edición con anotación filológica, aparato de variantes, bibliografía actualizada, además de un estudio de conjunto sobre los varios aspectos que emanan del quehacer poético cervantino.

\section{El Persiles}

La celebración del V Congreso Internacional de la Asociación de Cervantistas, celebrado en Lisboa, del 1 al 5 de septiembre de 2003, y convocado bajo el lema «Peregrinamente peregrinos» era una invitación a reflexionar sobre $E l$ Persiles. Las actas de este congreso confirman la atracción que la obra póstuma de Cervantes ejerce en la crítica de los últimos años. A los números me remito. Tres de los cuatro plenaristas eligieron El Persiles como tema de su intervención y sobre él versaron una treintena larga de comunicaciones. Y es que la brevedad de la estancia de los peregrinos en Lisboa es inversamente proporcional a la importancia que adquiere todo lo lusitano, como pregona el grito alborozado del grumete al divisar tierra: «iAlbricias, señores, albricias pido y albricias merezco! ¡Tierra! ¡Tierra! Aunque mejor diría: ¡Cielo! ¡Cielo! porque sin duda estamos en el paraje de la famosa Lisboa» (Persiles III, cap. I); palabras que abren el diálogo de la presencia cervantina en las letras portuguesas (Abreu, 2004) y que sirven de acicate para homenajear a la ciudad lusitana y a sus gentes, en sintonía con la invitación que Cervantes hiciera en el epitafio de Manuel de Sousa (Uriarte, 2004; Mãrculescu, 2004 y Roig, 2004).

El Persiles es la obra cervantina que en estos momentos está cobrando mayor relieve y en la que se está produciendo una revisión más radical de su interpretación. El hecho de que hasta los años noventa se hubiera leído como una obra tridentina casi de manera unánime ha propiciado que esta lectura se agotara, favoreciendo una apertura ávida de aire fresco. Esto no implica que la lectura seria, que cifra el valor máximo de la obra en la ejemplaridad y en los valores religiosos, haya desaparecido, pues todavía hoy sigue teniendo un peso mayoritario. La lectura alegórica simboliza en la peregrinatio vitae $\mathrm{y}$, por semejanza, en la peregrinatio amoris el valor más universal y permanente de la condición humana (Soupault Rouane, 2004 y Grilli, 2004). Aurora 
Egido (2004), en esta misma línea, rastrea a lo largo de la obra y, también, de la literatura áurea, el sentido del término «trabajos», profundizando el esbozo trazado hace años por Enriqueta Terzano. Trabajo y peregrinación conforman los ejes que simbólicamente articulan el relato ejemplar. Para Egido, Cervantes en El Persiles representó el ideal de los verdaderos «trabajos» del hombre de su tiempo, convirtiéndolos en «sustancia narrativa». En estrecha relación con la lectura alegórica se sitúa la función de los sueños ficcionales y la visualización teatral y alegórica (Chen Sham, 2004 y Suárez Miramón, 2004) o la alegoría filosófica propuesta por Antonio Gagliardi (2004).

El sentido católico de la novela, cifrado en la orientación mariana, alcanza su punto culminante en las octavas que Feliciana de la Voz entona ante la Virgen de Guadalupe. Para Aurora Egido constituyen «una versión mariológica ascensional» en clave poética semejante a los efectos producidos por el órgano de Salinas en la Oda de fray Luis (Egido, 1998 y Micozzi, 1995). Esta orientación mariana rara vez ha sido cuestionada pero, en tiempos recientes, se ha venido complementando, cuando no sustituyendo, por las doctrinas paulistas, haciendo del discurso de El Persiles una poética de la salvación cristiana (Armstrong-Roche, 2004; Parodi de Geltman, 2004; Wheaton, 2004 y Boruchoff, 2001). Críticas con esta lectura, están emergiendo nuevas aproximaciones que se distancian de la interpretación tridentina dominante en años anteriores, interpretando la exaltación exacerbada de la fe como expresión de la palabra crítica, unas veces orientada hacia la religión (Blanco, 1995), otras, hacia un discurso a doble voz (Lozano-Renieblas, 1998). Para Georges Güntert (2011), es posible interpretar el discurso de El Persiles con una lectura doble, entre cuyos extremos, siempre irreconciliables, media una distancia que permite activar el resorte de la ironía. Maurice Molho (1995), en continuidad con la línea apuntada, desgrana el polémico tema de la astrología, tan importante en la interpretación de la obra desde Cesare de Lollis y Américo Castro. Para Molho los personajes de El Persiles, siguiendo el aristotelismo materialista y racionalista de la escuela de Padua, practican una doble verdad bajo el velo del catolicismo, que se manifiesta de forma contundente en el episodio de la endemoniada Isabela Castrucha. Una segunda línea que emerge con fuerza es la revisión de El Persiles como libro ejemplar. Para Agustín Redondo (2004), apoyándose en las palabras que escribiera Cervantes en la «Dedicatoria» al conde de Lemos, lo que hace de El Persiles una obra de entretenimiento es el «placer del texto» que provoca una lectura libre de las ataduras ejemplares. La noción de libro de entretenimiento implica asimismo una reivindicación de su estética y del afán experimentador de su autor, cuyo proyecto artístico no se contiene ni en los límites de la novela de aventuras, ni en la renovación que supuso la narrativa de Heliodoro (Lozano-Renieblas, 2004; Alcalá Galán, 2004 y Boruchoff, 2004). Los acercamientos desde el culturalismo o posiciones afines se dejan notar en la preocupación por leer la obra como una construcción de la identidad en continua pugna con el otro que se manifiesta en el cruce cultural como generador de tensiones que cues- 
tionan el pensamiento eurocentrista (Matzat, 2004; Martín Morán, 2004 y Suárez, 2004).

Queda por mencionar un conjunto de trabajos dedicados a temas misceláneos que acogen una actitud plural hacia El Persiles, lo que confirma la vitalidad crítica de esta obra marcada por la homogeneidad. Entre ellos cabe destacar los dedicados a: episodios o personajes, (Palazón, 2004; Stoopen, 2004; Önalp, 2004; Salgado, 2004 y Rull, 2004); el sentido de la astrología y los cánones del pensamiento de la época, el análisis del discurso poético y la influencia petrarquista, los juegos, la presencia de la zoología fantástica y la geografía remota, la despedida de El Persiles como fórmula recurrente en autores y tiempos posteriores, el peso de la mitología clásica en la onomástica, cuestiones de ecdótica o la aclaración de expresiones en desuso (Cruz Casado, 2004; Mata Induráin, 2004; Colahan, 2004 y 2014; Moner, 2004; Díaz de Alda Heikkilä, 2001; Montero Reguera, 2004a; Ruffinatto, 2004; Baquero Escudero, 2004; Zamora Calvo, 2004; Suárez Miramón, 2011; López Férez, 2011; Fernández García, 2001 y Romero, 2001).

\section{Novelas Ejemplares}

El balance que arrojan los trabajos dedicados a las Ejemplares es más bien pobre si se compara con otras obras mucho menos del gusto de la crítica, como el teatro o El Persiles. Dos factores podrían explicar este hecho. Por una parte, el debate sobre las Novelas ejemplares ha estado fuertemente cohesionado en torno a la ejemplaridad y sus adláteres, a pesar de los esfuerzos de Unamuno por arrebatársela al terreno moral. Por otra, no es un asunto menor que se trate de una colección de relatos breves que se presta al fraccionamiento en detrimento de una comprensión de conjunto. Estos dos hechos han propiciado cierto agotamiento en el quehacer crítico sin que se haya producido la necesaria renovación. Es más, solo en el congreso de Oviedo se reservó una conferencia plenaria a la colección ejemplar. En ella Isabel Lozano-Renieblas (2014) revisa la noción de lo cómico en las Ejemplares. Explica que la propuesta cómica de Cervantes debe comprenderse desde la nueva sensibilidad que emerge en torno a 1600 , que subordinaba lo ridículo a la admiración producida por la novedad, como componente integral de los géneros cómicos.

El problema de la identidad adquiere un especial relieve, en el ámbito de las Ejemplares, tanto en su perfil alegórico o teológico como ejemplar (Parodi de Geltman, 1998; Mierau, 2011 y Arena, 1998). Otros temas estudiados son: el jardín, entendido como el espacio mítico que articula la cosmovisión en El celoso extremeño (Vita, 1998); el tratamiento de la mujer en el conjunto de la colección (Blanco-Camblor, 2004); los recursos retóricos (Gorla, 1998), la relación con el género de la novella (Lozano-Renieblas, 2008), o el léxico «de la germanía» (Martinengo, 1998). El interés por la écdotica lo rescata Romero (1995), quién tras un análisis pormenorizado de los problemas 
textuales en La gitanilla, propone volver a la lección de la princeps, en la línea de Florencio Sevilla y Antonio Rey Hazas.

En cuanto a las preferencias, todavía persiste el gusto por las llamadas novelas «realistas», en especial El coloquio de los perros. Rojas Otálora (2001) explica el Coloquio de los perros desde una perspectiva sociológica mientras que Alcalá Galán (2001) lo lee en clave metaliteraria, como una reflexión sobre el proceso mismo de la escritura. De las relaciones intertextuales con la picaresca, se ocupa Mañero Lozano (2011); de la risa del arbitrista al final de El coloquio, Roca Mussons (1995), de la canifilia, Martín (2004); y de la violencia en Rinconete y Cortadillo, Olid Guerrero (2014). En cuanto a La gitanilla, Hutchinson (2001) se adentra en la formación del personaje de Preciosa como encarnación del valor y Pabón (1995) retoma la relación entre Preciosa y la Poesía. Las aproximaciones a El amante liberal se polarizan entre la lectura alegórica y la sociológica (García Pascual, 2004 y Luttikhuizen, 2001). La española inglesa se aborda desde su contextualización histórica para explicar tanto el género al que pertenece como para justificar los recursos historiográficos que el autor utiliza al servicio de la narración (Lozano-Renieblas, 2011 y Montcher, 2011). Las novelas italianizantes, en cambio, tienen una presencia mucho más modesta y solo Las dos doncellas, entendida como celebración del rito de la confesión, es objeto de atención por Marsha S. Collins (2001).

Como en el caso de El Quijote el apartado de influencias adquiere un protagonismo un tanto desequilibrado en comparación con los trabajos dedicados a las mismas novelas. Rodríguez Luis (1998) explora la influencia de Cervantes en Defoe; Barrado de Álvaro (2011) se acerca a las traducciones de Rinconete y Cortadillo en Alemania como una visión del Imperio; Salgado (2014) rescata una posible influencia del Satiricón de Petronio en la figura de Vidriera; García López (1995) vincula El licenciado Vidriera a los relatos de Bandello; y Michael Gordon (2014) rastrea, en El amante liberal, las relaciones entre Cervantes y Shakespeare.

\section{El Quijote}

La celebración del IV CINDAC en Lepanto (2000) coincidió con el cambio de milenio, momento propicio para hacer balance de las tendencias del cervantismo durante el siglo que acababa de terminar. A José Montero Reguera le correspondió exponer los resultados de la primera mitad del siglo XX, organizando su exposición entorno al centenario del Quijote de 1905, la fecha de publicación de El pensamiento de Cervantes (1925) y el cuarto centenario del nacimiento de Cervantes (1947). Esta etapa está marcada, sobre todo, por el descubrimiento del Quijote. Los grandes nombres de la Filología y de la Romanística (Auerbach, Spitzer, Hatzfeld) demuestran sus hipótesis de trabajo con la obra cervantina y la sitúan en el dominio de la crítica entre las obras maestras (Montero Reguera, 2001). José Manuel Martín Morán (2001) pasó revista a la segunda mitad del siglo, caracterizada por el influjo de «el pen- 
samiento» de Castro que invade toda la crítica y consolida la lectura seria del Quijote. Al mismo tiempo va emergiendo una corriente cómica, que acabará por aproximarse, en el ocaso del siglo, a la lectura seria desde los presupuestos del eclecticismo. Me parece significativo que los escasos trabajos que tratan de la historia de la crítica del Quijote, excepto el de Anthony Close, se remitan al pasado y no a la época actual, fiel trasunto de la saturación que lleva aparejado un cierto inmovilismo crítico (Dotras, 2008; Piñero Valverde, 2008; Villanueva Fernández, 2008 y Romo, 2008). Close (2008) explica con clarividencia los logros y aportes críticos de los hispanistas franceses Monique Joly, Agustín Redondo y Maxime Chevalier, vinculados a la «Escuela de los Annales» o «Nouvelle Histoire», que, sobre todo, los dos primeros, han consolidado la interpretación cómica del Quijote. Se trata de un homenaje a una de las corrientes interpretativas más dinámicas y brillantes de la obra de Cervantes que hay en la actualidad.

Si en otro tiempo el «fantasma de la teoría literaria» ocupaba un lugar privilegiado en la investigación sobre el Quijote, en la actualidad se ha producido un cierto relajamiento, aunque perviven preocupaciones teóricas que presentan un amplio abanico de posibilidades, que va desde la ecdótica, hasta la narratología o la neorretórica. Los problemas ecdóticos han avivado, en los últimos tiempos, un debate en torno al valor que debe asignársele a la princeps (Martínez Pereira y Torné, 2008 y Martínez Pereira, 2014). Se ha impuesto una revisión de la actitud reverencial que el cervantismo convencional le otorgaba a la princeps, actitud inaceptable para unos (Rico, 2014), para otros justificable y, a veces, única posible, pues no contamos con el auxilio del manuscrito autógrafo. Francisco Rico rechaza la hipótesis de Robert Flores de que en la composición de la princeps del Quijote intervinieron cuatro cajistas, alegando que los indicios tipográficos y ortográficos en los que se basa Flores no son concluyentes y no avalan dicha hipótesis, pues la grafía de un libro no era, en la época, tanto un asunto del autor cuanto de la imprenta (Rico, 1998). En el marco de la renovación de la ecdótica tradicional, la novedad viene de la investigación llevada a cabo por el proyecto Cervantes que pretende abrir la obra cervantina al mundo digital y se propone elaborar la «edición variorum electrónica del Quijote» que sirva de punto de partida para la investigación del nuevo milenio (Urbina, 2001).

Junto a la autoridad de la princeps, también está en jaque el valor de la palabra autorial. Esta se manifiesta en las dudas y recelos que generan los narradores del Quijote, interesados en destruir la fiabilidad de la historia y dotar al relato de una ambigüedad artificiosa (Martín Morán, 1995). Esta ambigüedad se extiende tanto al traductor como al lector del capítulo nueve, gracias a los cuales podemos continuar leyendo la novela, e incluso va más allá de los prologuillos internos, donde el autor vierte sus vacilaciones sobre el proceso narrativo (Maspoch Bueno, 1995; Stoopen de Morfin, 1995 y Porqueras Mayo, 1998). Solo escapan parcialmente a este debilitamiento de la palabra autorial, los prólogos de la obra, como lugar privilegiado para la reflexión sobre la escritura, donde asoma el auténtico escritor (Stoopen de 
Morfin, 1998 y Álvarez Amell, 1995). Este espacio que cuestiona la autoridad del autor se configura como un principio de libertad creadora que confiere al relato un rasgo de modernidad (Martín Morán, 1998). Otro rasgo de modernidad que emana del debilitamiento de la palabra autorial lo aporta el diálogo que, al tiempo que permite contraponer perspectivas encontradas del mundo, se erige en instrumento de la omnisciencia narrativa (Martín Morán, 2014). La tendencia de proyectar en el Quijote la contemporaneidad del lector es cuestionada por Close (2011), quien enmienda la plana a la arraigada tradición crítica que ha mantenido que el Quijote es una obra profundamente metaléptica, señalando las profundas diferencias que separan el concepto de metalepsis antes y después de 1800. Esta reflexión teórica recoge asimismo los ya clásicos debates entre novela y épica (Alcalá Galán, 1998); el análisis de la estrategia discursiva o la interpretación del diálogo desde una perspectiva sociolingüística y de la pragmática del lenguaje (Costa Vieira, 2014; Endress, 1998; García-Page, 2001 y Morales, 2001); la configuración irónica del texto y los límites de la parodia (Hidalgo Serna, 1998; Piskunova, 1998 y Pastrana Santamarta, 2014); las transformaciones de motivos caballerescos y su relación con los libros de caballerías (Urbina, 1998; Duce García, 2001; Eisenberg, 2001; Boscán de Lombardi, 2001 e Illades Aguiar, 2008); los recursos retóricos en el trazo del retrato femenino desde la tradición del canone breve o desde el topos petrarquista (Rodríguez, 1998 y Ruta, 1995); la presencia del mundo clásico y de la Biblia (Chul Park, 2001; Cascardi, 2001; López Férez, 2008; Merkl, 2008 y 2014 y Fine, 2001); y cuestiones temáticas con implicaciones teóricas (Martín Morán, 2008 y Martín, 2014) o lingüísticas (García Sánchez, 2008 y Cash, 2008). El influjo de la corriente culturalista ha impulsado el estudio de temas relacionados con la identidad y el feminismo, y ha renovado el de las relaciones con el mundo otomano (Hutchinson, 1998; Dotras Bravo, 2014; Alcalá Galán, 2014; Abi-Ayad, 1995; Gallota, 1995 y Ohanna, 2014).

Por otra parte, el acercamiento del lector a la obra o lo que en la crítica norteamericana se conoce como «reading response» emerge desde el otro lado del Atlántico en la implicación existente entre el lector actual y el «desocupado lector» (Stoopen de Morfin, 2001 y Díaz Migoyo, 2001). Los estudios de Roger Chartier sobre la historia del libro y su interés en la materialidad de los objetos culturales, y su relación con los procesos sociales se ponen de manifiesto en la intersección entre la oralidad y la escritura y en los problemas de aculturación (Castillo Gómez, 2001 y Sierra Macarrón, 2001). Porque al fin y al cabo, como escribe Aurora Egido (2011), el Quijote es una invitación al gozo de la lectura que corre parejo al placer que genera el acto de la creación literaria. Rey Hazas (2008), partiendo del uso de los términos católico y cristiano, vuelve sobre el viejo debate de la datación de las obras cervantinas; Martín Jiménez retoma las disputas literarias entre Cervantes y Lope de Vega (2014); y Howard Mancing (2014), apoyándose en el concepto de autopoiesis, propone, desde la interdisciplinaridad de las ciencias cognitivas, recuperar la «biología» para los estudios literarios. 
La construcción del personaje en el Quijote se erige en una de las prioridades, sobre todo, en los trabajos publicados en las Actas del III CINDAC (Menorca, 1998). Se subraya como rasgo caracterizador la falta de vínculos genealógicos o el uso de la inverosimilitud a través de personajes espejo con fines ideológicos (Moner, 1998 y Alcalá Galán, 2014). María Augusta da Costa Vieira (1995) se centra el valor de la palabra en don Quijote, que oscila entre la fe absoluta y la necesidad de ser refrendada por la letra escrita. Morón Arroyo (1995) renueva el personaje sanchesco a la luz de la doctrina de las potencias del alma. Iffland (1995), tomando como punto de partida una sugerencia de Agustín Redondo, llega a la conclusión de la raíz festiva del cura Pero Pérez. Para Lozano-Renieblas (2001) la configuración de Sansón Carrasco debe mucho a su relación intertextual con La Celestina y Romero Muñoz (2004), escudriñando el texto quijotesco, traza un retrato físico y moral del genio y figura de Teresa Panza.

En cuanto a los episodios, la modernidad parece inclinarse por los de la segunda parte. Agustín Redondo (1998) relaciona el episodio de Altisidora con el resurgir del entretenimiento cortesano de tipo bufonesco en la corte de Felipe III. El episodio responde a una construcción típicamente carnavalesca, como un mundo al revés, en el que se produce una inversión en la relación entre el galán y la dama. Asimismo de las tres imágenes de santidad que se entrecruzan en el episodio del Caballero del Verde Gabán, le corresponde una «santidad laica» a don Diego de Miranda, «que monta a la moruna, en una yegua tordilla y que domina el color negro», sugiriendo una imagen invertida de Santiago Matamoros (Redondo, 1995). Estos rasgos en la vestimenta del Caballero del Verde Gabán lo vinculan al mundo morisco (Morales, 2014) y me pregunto si esa manera de hablar con doña Cristina, muy parecida a la de don Álvaro Tarfe, al igual que otros signos ambiguos, no apuntarán en la misma dirección. El género pastoril, que experimenta una reelaboración a través del filtro de los episodios del Quijote, juega un papel central en el devenir del héroe quijotesco así como en el diseño arquitectónico de la novela (Suzuki, 2014). Mariscal (1998) destaca el episodio de las bodas de Camacho por la peculiar utilización de un género pastoril prácticamente desaparecido en la época de Cervantes. Roig (1995) se detiene en los aspectos novedosos que presenta el episodio de Roque Guinart; Porqueras Mayo (2001) y Vila (2001) rescatan episodios menos transitados por la crítica como el de Claudia Jerónima. Otros más clásicos, como el de la Cueva de Montesinos, se interpretan como un studiolo ideal de erudito (Bernat Vistarini, 2001b). En cambio, la selección de los episodios de la primera parte del Quijote es mucho más modesta. Destaca la preferencia por las narraciones intercaladas, como el Curioso impertienente (Illades Aguiar, 1995 y Bailón Blancas, 1995) o el cuento del caballero del Lago (Finello, 1995). Queda por mencionar un conjunto de trabajos misceláneos de temas muy variados. Layna Ranz (2014) ilumina el sentido de «La liebre y la jaula de grillos» que aparecen al final del Quijote. Neumeister (1995) transita por los senderos del engaño para explicar cómo los encantadores son el ancla que amarra la visión del mundo 
de don Quijote. Parodi de Geltman (1995) formula la hipótesis de una estructura alegórica a partir la segunda salida que apunta hacia la obra redentora de Cristo. Y para terminar con este apartado, José Manuel Lucía Megías (2008) traza, desde la iconografía, el tratamiento del episodio de la investidura a través de los siglos, desde las primeras imágenes cómicas hasta llegar a la «serificación» del siglo XIX, donde el acto de investidura se cubre de cierta solemnidad.

Los esfuerzos por conocer la identidad del autor del Quijote apócrifo han venido siendo una constante desde la publicación de la obra en 1614. Y en esta trayectoria la candidatura de Ginés de Pasamonte ha ido cobrando cada vez más fuerza. A pesar de ello, Edward Riley (2008) cuestiona seriamente que Ginés de Pasamonte sea Avellaneda, porque en él concurren una serie de condiciones que hacen materialmente imposible que pudiera escribir el apócrifo. De otro candidato, Juan Valladares de Valdelomar, se ocupa Cruz Casado (2008), que vuelve sobre una vieja hipótesis de Arturo Marasso. Al interés por desentrañar la identidad de Avellaneda, hay que sumar un cierto desplazamiento de la investigación hacia el peso que adquiere el texto apócrifo y la huella que ha dejado en la escritura cervantina (Gómez Canseco, 2008 y Nishida, 2008). Para Williamson, a partir del capítulo 59 hasta el final, el impacto de Avellaneda caló hondo hasta el punto de modificar el rumbo de la novela. La publicación del apócrifo forzó a Cervantes a dilatar la parodia teniendo como resultado una dinámica mucho más profunda entre don Quijote y Sancho que, a la postre, convertiría la obra en el gran mito que es en la actualidad.

La celebración del VI CINDAC (Alcalá de Henares, 2006) estuvo marcada por el rescoldo que dejó el IV centenario de la publicación del Quijote. Como era de esperar, el despliegue de congresos y actos públicos convocados habrían de influir necesariamente en el contenido de los trabajos presentados. Destaca la difusión del Quijote tanto en el ámbito de las artes escénicas y la música (García Lorenzo, 2008) como su alcance mediático (Moreno, 2008; Blanco Mallada, 2008 y Chaparro Domínguez, 2014). Dentro del capítulo de la difusión, adquiere especial relevancia el cambio de rumbo que se produce en los criterios de traducción. Podría decirse que la tendencia general es una vuelta a las traducciones fieles a la princeps, incluso imitando el estilo cervantino, efectuadas no tanto por traductores profesionales cuanto por profesionales con preparación fillológica, buenos conocedores de la obra cervantina (de la traducción al inglés se ocupa Lathrop, 2008; al hindi, Maurya, 2008; al italiano, Botta, 2008).

En el capítulo de recepción e influencias llama la atención el lugar privilegiado que ocupa en las actas de los dos últimos congresos, celebrados en Münster (2009) y en Oviedo (2014). En este último, el término internacional adquiere un sentido especial por dos razones. La primera tiene que ver con los lazos con la Cervantes Society of America, como representante de cervantismo norteamericano. Por primera vez, aparece publicado en las actas el encuentro formal entre el cervantismo norteamericano y el europeo para de- 
batir sus discrepancias y semejanzas. Esto augura una relación más fluida y, sin duda, el diálogo iniciado servirá de acicate para encuentros futuros (AlcaláGalán, Hutchinson, Layna y Martín, 2014). La segunda tiene que ver, como escribe Emilio Martínez Mata en la introducción a las Actas del VIII CINDAC, con el gran número de trabajos dedicados a la recepción del Quijote. La explicación de esta tendencia es fácil de entender: la enorme influencia del Quijote en la literatura posterior. Esa influencia se ha ido agrandando con el tiempo y lo hará todavía más su reconocimiento. Baste una breve muestra para hacerse idea del espectro que abarcan los trabajos dedicados al impacto cervantino en obras de las literaturas uruguaya, serbia, japonesa, eslovena, italiana, inglesa, lusobrasileña, griega moderna o india (González Briz, 2014; Guzina, 2014; Tomita, 2014; Kalenič Ramšak, 2011; Scaramuzza Vidoni, 2011; Quinziano, 2014; Borham Puyal, 2014; Valdés Rodríguez, 2014; Pérez Rodríguez, 2011; Vargas Díaz-Toledo, 2011; Filippís, 2001; Villar Lecumberri, 2011 y 2014 y Maurya, 2014). Se nos han quedado en el tintero los trabajos sobre Machado de Assis, Jorge Guillén, Ungaretti, Auden, Torrente Ballester, Shakespeare, Carlos Fuentes, Walter Scott y un largo etcétera que no se agota en esta apretada enumeración. No estaría completo este apartado sin referirme a la labor que lleva a cabo el proyecto «Recepción e interpretación del Quijote (16051800). Traducciones, ediciones, opiniones» en España, Francia, Italia, Alemania e Inglaterra, encabezado por Emilio Martínez Mata (2014) y que da fe de esta preocupación por la suerte de Cervantes en los anales de la historia literaria.

Esto es, en apretada y breve síntesis, lo que han dado de sí los primeros ocho congresos de la Asociación de Cervantistas. Quizás el balance que queda apuntar ahora es que parece concluir una primera etapa de la Asociación. Los primeros veinticinco años han estado marcados por la herencia de la escuela española de filología. El siglo XXI ha abierto una gran crisis de los estudios literarios y de las humanidades en general. El cervantismo no es ajeno a esa crisis y demanda nuevas propuestas. Quizás sea el momento de profundizar el diálogo con los cervantistas europeos y de otros continentes, pues parece ineludible reunir esfuerzos para acometer nuevos retos y esbozar la lectura de la obra de Cervantes que exige el nuevo milenio.

\subsection{Entre congresos y coloquios: notas de un secretario 22}

Enfrente del portal de la iglesia de San Nicolás, abriéndose a la vieja Plaza del Mercado, admiraba el escaparate rococó abarrotado de frutas confitadas de todos los colores, chocolates de cacao exótico, pasteles legendarios de factura imposible que solo allí, bajo la luz reflejada en las molduras doradas y las cornucopias, tentaban de manera tan irresistible a los vecinos de Palma 
desde muchas generaciones atrás. La apoteosis del local llegaba en Navidad. Las colas de gente abrigada, entre aromas de miel y vainilla, se repetían un día tras otro durante casi todo el mes de diciembre para comprar turrón. Mi madre me mandaba cada Nochebuena a por huevo hilado - del turrón se encargaba mi padre- según un ritual inamovible, tan fijo como el canto de la Sibila en maitines. Entonces podía admirar también la elegancia de los paquetes de dulces anudados con un fino cordón azul y blanco, pero sobre todo el trato especialmente suave que se dispensaban allí dentro los conocidos al saludarse en un ambiente tan cálido; y podía ver, sin saber aún quien era, a José María Casasayas entrando y saliendo del obrador de Can Frasquet, su confitería. Era, por entonces, un señor con bigote. Su rostro, muy parecido al del retrato sepia que presidía la sala desde lo alto de unos estantes, demostraba la continuidad del negocio familiar y reforzaba la sensación de estar en un refugio donde el orden natural de las cosas debía producir necesariamente dulces exquisitos y una prodigiosa cordialidad.

Con los años seguí cumpliendo cada Navidad el ritual del huevo hilado. Pero además, una o dos veces por semana, atravesaba la confitería, entraba en el obrador y subía por la estrecha escalera donde bandejas y cajas listas para ser enviadas a cualquier lugar del planeta iban cediendo espacio, escalón a escalón, a libros y papeles hasta llegar a un gran despacho de suelo y paredes de madera, a medias iluminado por unos ventanales con cortinas hasta el suelo y una araña de cristal siempre encendida, todo presidido de forma solemne por un macizo escritorio de roble. Entre dos estanterías, una escalera aún más estrecha que la anterior conducía a una buhardilla igualmente atestada de libros. Allí tenía a mi alcance -como cualquiera que se quisiera acercar- una de las mejores bibliotecas cervantinas particulares del mundo, y me pasaba las horas devorando lecturas como si fueran las golosinas de la planta de abajo. La generosidad de José María llegaba al extremo de dar libre acceso a su fotocopiadora, y con ella me hice un pequeño archivo personal de artículos difíciles de hallar y páginas de estudios que prefería releer más despacio en casa. En aquel tiempo, hablo de finales de los años 80, José María intentaba poner orden en su colección y a tal fin armó unos enormes ficheros de contrachapado donde describía por extenso todos sus libros y todos los artículos que tenía, incorporando en algunas de aquellas fichas tamaño DIN A5 resúmenes y notas personales. Pronto la tarea creciente exigió ayuda y pude encaminar hacia la biblioteca a varios alumnos de la Universidad para que ayudaran a fichar y ordenar. Nunca logré convencerle de que tanta información como almacenaba, y más que iba a agolparse allí en años venideros, exigía el uso de un ordenador de verdad y no de aquella máquina de escribir con un rudimentario y lábil sistema de archivo electrónico que él tanto amaba.

En aquellas horas había tiempo para la conversación. No solo cervantina o erudita, claro está. José María tenía opiniones contundentes sobre cualquier cosa, y en su ejercicio profesional de abogado había vivido situaciones que contaba a veces con regocijo y otras con justa indignación. Pero desde nues- 
tros primeros encuentros vi como aumentaba sin tregua su voluntad de lanzar la Asociación de Cervantistas a la actividad incesante que luego desempeñaría. Antes tuvo que vadear un período personal muy difícil: un gravísimo accidente de coche y la operación de garganta que le dejó sin voz. No vale la pena hablar de ello ahora pero años después, metidos en los intríngulis de la organización de un congreso, sentados en su casa ya de noche tras una jornada larga de trabajo, me dijo poniéndose serio: «Antonio, otros en mis circunstancias se dedican a beber. Yo me dedico en cuerpo y alma a estas cosas», y señaló con un movimiento circular los archivadores en que guardaba, por orden alfabético y hasta el último fax, la inacabable correspondencia con los socios de la AC o con cualquiera que tuviera que ver, ni que fuera remotamente, con sus actividades.

José María había urdido un plan del que me hizo cómplice. Fue después del congreso de la AC de 1994 que dirigió Giuseppe Grilli en Nápoles. Por aquel tiempo, cada vez que llegaba un cervantista a casa de José María, cosa frecuente, hacíamos todo lo posible para que se acercara a mi Facultad a hablar a los estudiantes de Siglo de Oro o a dar una conferencia abierta. La nómina incluye a Francisco Márquez Villanueva, Daniel Eisenberg, Eduardo Urbina, Carlos Romero, Carlos Alvar, Helena Percas de Ponseti... Fueron muchos más, pero menciono solo a algunos cuyas visitas se repitieron en varias ocasiones.

Estas visitas abrieron el camino a otros encuentros, como los que precedieron a los congresos internacionales: así los tres coloquios celebrados con el firme apoyo del Centro de Estudios Cervantinos en el remozado Palacete Laredo de Alcalá de Henares (1990-1993); después vinieron otras colaboraciones, como el acuerdo suscrito con el ayuntamiento de Argamasilla de Alba en fechas posteriores.

El contacto con la Universitat de les Illes Balears (UIB) y la creciente entrega de José María a la Asociación de Cervantistas, ahora que se veía liberado de gran parte de sus obligaciones diarias, le llevó a proponer la venta de su biblioteca particular a la UIB. Durante unos meses elaboramos cuidadosamente el catálogo. Hubo sus más y sus menos en el proceso, como es de imaginar. Pero ninguna Universidad podría dejar escapar una biblioteca que no era un capricho de bibliófilo cargado de rarezas, sino un impresionante instrumento de trabajo, con colecciones completas de las mejores revistas, seguimiento de las más relevantes publicaciones y cientos de fotocopias encuadernadas artesanalmente de obras y documentos inencontrables. Al final, gracias al buen hacer del rector de entonces, Llorenç Huguet, la Biblioteca Casasayas forma hoy una sección de la que la UIB está especialmente orgullosa. El plan de José María era destinar la mayor parte del dinero obtenido a la organización de encuentros y publicaciones cervantinas. Y se entregó de inmediato a la tarea. En 1997, codo a codo, organizamos el III Congreso Internacional de la AC, en Menorca, en el Hotel Cala Galdana. Congreso recordado entre otras cosas por cómo aprovechaban el buen tiempo los participantes huyendo subrepticiamente en bañador hacia la playa durante las se- 
siones -con la reprimenda pública consiguiente de José María, que estaba al tanto de todo-. Otras aportaciones únicas de este encuentro fueron, por ejemplo, la invención de la categoría de «ponencia hemiplenaria» para restaurar la dignidad herida de un participante disconforme con una simple comunicación; o el control estricto del tiempo de las intervenciones por medio de un cronómetro de cocina en forma de tomate que sonaba como un demonio al cumplirse los veinte minutos de rigor. El ambiente agradable que propiciaba el grupo de estudiantes de la UIB que me ayudaban casó además como un guante con un congreso dentro del congreso - otra aportación insólita- dedicado cada tarde a las «desviaciones lúdicas de la crítica cervantina», promovido por un grupo de vida efímera autobautizado «Locos amenos». Las actas publicadas posteriormente dan fe de que nada de lo dicho hasta aquí menoscabó la calidad de los trabajos.

José María fue elegido al poco presidente de la AC y yo iba a ser su secretario hasta el final. La primera decisión importante que hubo que tomar fue gloriosamente insensata: celebrar el siguiente congreso en Lepanto. La complejidad inicial de la empresa satisfacía de por sí el tipo de retos que movían a José María. En su ánimo estaba, como me confesó en más de una ocasión, marcar con punto y aparte la historia de los congresos cervantinos, echar la casa por la ventana y retirarse luego con la satisfacción del conquistador. Ni qué decir tiene que no se retiró, como buen conquistador. Pero tampoco se conformó con las complicaciones de organizar, sin más, un congreso en un lugar difícil. Quien tenga un cartel de aquel evento o guarde su imagen en la memoria sabrá que en su parte inferior constan, además del logotipo de la $\mathrm{AC}$, los de hasta treinta instituciones más, encabezadas por la Casa de S. M. El Rey. Con todas lidió a su modo José María y, en ciertos casos, como ocurrió con el Ayuntamiento de Náupactos, duramente. Una pieza de debate principal en aquel tinglado fue la estatua de Cervantes - ¿o es un don Quijote?- de tamaño natural, en bronce, que encargó al escultor mallorquín Jaume Mir y cuya erección en Náupactos José María consideraba casi el acto central del congreso. Las discusiones con el escultor empezaron con el diseño de la obra, siguieron con la placa que se añadió al pedestal al llegar a Grecia, continuaron con su emplazamiento en el puerto de Náupactos -con airada intervención de unos concejales del ayuntamiento a quienes recuerdo vociferando y en un tris de llegar a las manos- y no cesaron sino meses después del congreso, alrededor de un caldero de arroz con centollo en casa de José María, donde, por fin, el escultor se dio por satisfecho con sus emolumentos. Pero la mejor consecuencia personal del empeño fue que nos obligó a José María y a mí a alquilar un coche en Barcelona -un coche grande donde metimos los cientos de kilos de materiales considerados necesarios para la secretaría del congreso- para ir luego a la fundición donde nos aguardaba la estatua recién embalada, contratar a dos operarios con una furgoneta, darles un mapa con la ruta hasta Náupactos y emprender camino hasta allí una semana antes del inicio de las sesiones. Más de una vez perdimos la pista de la furgoneta al cruzar Italia para llegar a Ancona, donde debíamos embarcarnos 
en el ferry que conduce a Patras. Aquel viaje en coche desde Barcelona a Náupactos, haciendo fonda en Génova y en Florencia para saludar a los amigos, con la inteligente compañía de José Zaforteza Calvet, fue inolvidable -por razones opuestas diré lo mismo del regreso, cuando José María decidió hacer la ruta Ancona-Barcelona de una tirada y sin respirar-. Hoy la estatua está en un lugar distinto del que tan trabajosamente conseguimos y, por las fotos que circulan en Internet, la mano derecha alzada a los cielos de don Quijote -¿o es Cervantes?- ha perdido la pluma que sostenía. La placa del pedestal todavía ostenta las erratas que nos enfadaron y que los griegos prometieron corregir; pero también resuena aún en mis oídos para consolarme -mejor: divertirme- la fanfarria militar de la banda que durante el descubrimiento de la escultura, en presencia de las autoridades civiles y religiosas de la zona y de una fragata española anclada ante la bocana del puerto, dio lustre a aquella mañana algo turbia e hizo infinitamente feliz a José María.

La aventura nos dejó agotados porque los problemas que hubo que solucionar antes, durante y después del congreso no acababan nunca. La ayuda entusiasta de Alicia Villar impidió más de una vez el deslizamiento hacia la catástrofe $\mathrm{y}$, a pesar de algunas tensiones -como la provocada por una huelga de autobuses que nos utilizó como rehenes bajo el Castillo de Náupactos para forzar sus reivindicaciones- tengo por cierto que el tiempo habrá salvado lo bueno en la memoria de los participantes. A los pocos meses, por su parte, José María ya estaba tramando todas las tareas que ocuparían a la AC hasta la sonora fecha de 2005. Pocas pudo llegar a ver cumplidas. No voy a reseñarlas aquí porque quiero únicamente dejar subrayado el valor del trabajo obsesivo que estaba llevando a cabo José María desde que le conocí, del que hablábamos a menudo -con algunas disensiones cordiales- y que estaba siempre abierto sobre su escritorio como un telar de Penélope: la traducción al catalán del Quijote. Era este el trabajo de su vida y en él andaba absorto en el mismo instante de su fallecimiento. Por supuesto, es la mejor traducción al catalán que se haya escrito y así debería ser reconocida sin ambages. Su deseo de incorporar equivalencias de todos los registros posibles y de jugar con los localismos y dialectalismos catalanes -desde una irreductible matriz mallorquina- la convirtió, no obstante, en una tarea titánica y, por definición, fluida y siempre perfectible. Pero es un tesoro de decisiones sabias que hay que saber leer decantando las contadísimas extravagancias que son fruto de la personalidad (¡ay!) de su autor y de su formación filológica autodidacta. Desde que su hijo Lluís y Alicia Villar la editaron respetuosamente en tres volúmenes en 2005, estamos a la espera de una lectura atenta y desprejuiciada. No creo exagerar si digo que hoy en día la situación de la lengua catalana exige más que nunca este esfuerzo. Si estas líneas sirven de llamada de atención, me daré con un canto en los dientes.

Hace unos días, al pasar por delante de la confitería de Can Frasquet, saludé como tantas veces a Jordi, el hijo de José María encargado del negocio. Es la última vez que entraré allí para dejarme envolver por el aroma de cacao, 
canela y frutas confitadas. Can Frasquet, me dijo Jordi, cerrará para siempre sus puertas antes de que llegue la Navidad. Ya es historia.

\subsection{La Asociación de Cervantistas ante el centenario de $2005^{23}$}

El verano de 2004 se presentaba especialmente halagüeño y tranquilo para una Asociación de Cervantistas que había dejado atrás no ya las dudas y reservas, sino la decisión firme de su presidente de abandonar la nave que había venido pilotando desde mucho tiempo atrás. En efecto, José María Casasayas expuso abiertamente en el congreso de Lisboa (octubre de 2003) su deseo de ceder el testigo a otra persona que continuara la labor por él emprendida. Con este sinsabor, pero también desafío, trabajamos juntos a lo largo del invierno de aquel año para llevar a cabo aquel propósito. Se barajaron posibles nombres en la idea de encontrar un nuevo capitán para la nave. Todo volvió a su cauce a comienzos del año 2004 cuando Casasayas me comunicó -no recuerdo si por teléfono o por fax-su cambio de parecer: no dejaba la presidencia de la Asociación de Cervantistas y me proponía que siguiera colaborando con él, con un propósito muy concreto: la elaboración de un Boletín de la Asociación de Cervantistas. Refrendo de esta nueva situación fueron las elecciones de febrero de 2004 en la que se eligió una nueva directiva encabezada por Casasayas, con Antonio Bernat Vistarini de secretario y yo mismo como vicepresidente. Así llegó la primavera y yo me dediqué con intensidad a la elaboración del mencionado Boletín, del que llegaron a salir tres volúmenes ahora accesibles, como todas las publicaciones de la Asociación de Cervantistas, en el portal que el Centro Virtual del Instituto Cervantes le ha dedicado.

Hallábame yo ocupado, pues, en la elaboración del Boletín, y, en lo que se me alcanza, Casasayas esperanzado por haber sido nombrado miembro de la comisión nacional para la celebración del cuarto centenario de la publicación de la primera parte del Quijote; conservo muchos faxes y cartas suyos de aquella primavera y comienzos de verano de 2004 hasta que, de pronto, súbitamente, se interrumpieron; al principio no le di importancia: las fechas estivales son propicias al retraso en el correo; me extrañó, sin embargo, porque José María era muy puntual en el correo. Pronto, las cañas se tornaron lanzas y una llamada de Antonio Bernat a principios de septiembre me dio de bruces con la realidad: «José María está muy mal», me dijo; yo intenté quitarle hierro al asunto y rebajar la tensión, sabedor de que Casasayas ya había pasado por trances médicos importantes, afortunadamente todos superados. Pero las palabras y el sentir de Antonio eran otros y rotundos; en efecto, unos días después, el 27 de septiembre, fallecía el abogado mallorquín que había creado, dado forma y sustentado durante quince años a la Asociación de Cervantistas.

23. Por José Montero Reguera. 
Circunstancia poco frecuente en este tipo de entidades -el descabezamiento imprevisto de una asociación de hispanistas-, los estatutos aprobados en febrero de 2004 sobre los fundacionales de 1988, para adaptarlos a la nueva ley española de asociaciones, indicaban con claridad el procedimiento: este era claro, pero el futuro para mí se cernía nublado, borrascoso incluso. En efecto, en estricta aplicación de los artículos 11.3. («En caso de su fallecimiento, imposibilidad física y mental, renuncia, ausencia temporal o apoderamiento [del presidente], será relevado en sus funciones por el Vicepresidente») y 12 («El Vicepresidente, que será uno de los junteros, ostentará el cargo por el mismo período y en las mismas condiciones que el Presidente, al cual relevará en todas sus funciones en los casos señalados en el artículo 11.3. o por delegación personal expresa. En su ausencia le sustituirá, si fuere necesario, el juntero más antiguo») hube de desempeñar las labores que me competían, de acuerdo siempre con la Junta Directiva elegida en febrero de 2004, con la que me reuní en la sede de la Sociedad Cervantina de Madrid (entonces al templo no habían llegado los mercaderes) el 22 de octubre de 2004. Fruto de esa reunión fue la circular que se envió a todos los socios dos días después en la que se informaba de las medidas y acciones que se habían tomado.

Tres eran los grandes retos que ofrecía la nueva situación: dos, digámoslo así, de puertas adentro; y un tercero, de cara al exterior. Los dos primeros tenían que ver con la propia administración y gestión de la entidad y con el proceso para elegir nueva junta rectora en un momento no fácil, no solo por el fallecimiento inesperado, sino también por el tercer reto que tenía entre las manos la entidad: en menos de dos meses comenzaba un año de celebraciones en el que la Asociación quería participar de forma muy activa y ya se habían iniciado contactos para su colaboración más o menos directa en media docena de actividades.

El ofrecimiento y disposición muy generosos de Carlos Alvar y Antonio Bernat permitió, en un inolvidable viaje a Palma de Mallorca, que yo pudiera tomar las riendas de cuentas, materiales, cuestiones pendientes y de otras muchas menudencias de diverso tipo (algunas poco gratas); hoy reconozco agradecido a Carlos y Antonio su ayuda, tan fundamental en aquel momento. Por otra parte, en la reunión celebrada el 22 de octubre se acordó «aplicar estrictamente el contenido de los artículos 11.3. y 12 antes referidos y continuar, con el Vicepresidente a la cabeza, la gestión iniciada en febrero de 2004, tras las elecciones del día 16; pero, al mismo tiempo, no agotar el plazo de los tres años de legislatura, sino convocar nuevas elecciones a lo largo de 2006, probablemente, si bien no se ha decidido de manera definitiva, en el transcurso del congreso que la AC debe organizar en ese año». Con estos dos primeros retos encauzados comenzó el tercero que llevó a la Asociación de Cervantistas a peregrinar por todo el mundo, ya antes incluso de comenzar 2005.

En efecto, fueron muchas las actividades en las que la Asociación de Cervantistas participó de manera muy activa; ello supuso un sinfín de gestiones 
que permitió proporcionar becas, facilitar traslados, consecución de ayudas y subvenciones; cartas, correos electrónicos y llamadas se sucedieron en un año y tres meses verdaderamente frenéticos. Voces y manos amigas hicieron más fácil y posible todo aquello: José Manuel Blecua Perdices, Aurora Egido, Javier Blasco, Santiago López Navia. Más nombres irán surgiendo a lo largo de estas páginas.

Los previos del centenario llevaron a la Asociación de Cervantistas a peregrinar por Oviedo y Seúl, todavía en 2004.

A Oviedo fue de la mano de la Cátedra Alarcos, a cuya directora, Josefina Martínez, y colaboradores más directos, Teresa Cristina García Álvarez y Emilio Martínez Mata, hay que reconocer un trabajo impecable que dio como resultado un excelente coloquio (y un libro muy bien editado), en el que se unieron la Universidad de Oviedo y Ayuntamiento de esta ciudad con la colaboración de la Asociación de Cervantistas. El Coloquio Internacional «Cervantes y el Quijote» se celebró en Oviedo del 27 al 30 de octubre de 2004 y reunió, en el salón de actos de la Biblioteca de Humanidades «Emilio Alarcos», a una numerosa concurrencia de profesores y estudiantes que, tras la conferencia inaugural de José María Merino, pudieron atender a más de veinte comunicaciones y cuatro ponencias plenarias a cargo de Anthony Close, Mary Gaylord, Javier Blasco y Jean Canavaggio.

Poco después, entre el 16 y 20 de noviembre, la siguiente parada fue al otro lado del mundo, de la mano del siempre cordial Chul Park, en Seúl, donde se celebró el XI Coloquio Internacional de la Asociación de Cervantistas. Allí, a través de las ponencias plenarias, conocimos los planes del Instituto Cervantes con respecto al IV centenario de la publicación del Quijote en boca del director del Instituto Cervantes de Manila, D. Javier Galván Guijo; también de las perspectivas del hispanismo en los albores del siglo XXI a través de las palabras del presidente de la Asociación Internacional de Hispanistas, prof. Jean François Botrel; y, a caballo entre la retrospectiva histórica y la proyección futura, el profesor Chul Park informó sobre el laborioso hispanismo-cervantismo coreano; Francisco Márquez Villanueva, ofreció una revisión del personaje de don Quijote, y Gonzalo Díaz Migoyo revisó, con su perspicacia habitual, un comprometido personaje de la segunda parte del Quijote (Ricote).

El amplísimo número de ponencias presentadas, casi una cincuentena, en su variedad, dio muestra de la vitalidad de los estudios cervantinos y de la pujanza del cervantismo coreano: una grata realidad que en aquellos días quedó confirmada de manera rotunda. Muchas fueron las personas y entidades que colaboraron en el éxito de la empresa: la Asociación Coreana de Hispanistas y el Instituto de Estudios Iberoamericanos de la Universidad Nacional de Seúl con los profesores Chul Park y Lee Man Ki al frente de un amplio equipo organizador; la Asociación Asiática de Hispanistas, y una larga lista de entidades públicas y privadas.

Ya en el año del centenario, la Asociación de Cervantistas organizó o colaboró directamente en la organización de cuatro coloquios internacionales: 
Delhi (31 de enero-2 de febrero), Argamasilla de Alba (6-8 de mayo), Buenos Aires (20-23 de septiembre), y Jerusalén (19-21 de diciembre).

Bajo la dirección conjunta de Vibha Maurya (Departamento de Estudios Románicos y Germánicos de la Universidad de Delhi) e Ignacio Arellano (GRISO, Grupo de Investigación Siglo de Oro de la Universidad de Navarra) se celebró el Coloquio Internacional Cervantes y el Quijote, con la colaboración de la Asociación de Cervantistas. Este evento tuvo tugar en el India International Centre de Nueva Delhi durante los días 31 de enero, 1 y 2 de febrero de 2005.

El coloquio se abrió con una sentida sesión de homenaje a José María Casasayas en la que intervinieron el Excmo. Sr. D. Rafael Conte, Embajador de España, los directores del coloquio, profesores Arellano y Maurya, la decana de la Facultad de Artes y José Montero Reguera.

Las sesiones se desarrollaron tanto en inglés, mayoritariamente, como en español, con intervenciones de hispanistas procedentes de India - una grata sorpresa el trabajo hispanista que allí encabeza la profesora Maurya-, pero también de los Estados Unidos (Joseph Ricapito, Robert Lauer, Jordi Aladro), España (Carlos Mata, Francisco Javier Díez de Revenga, Fernando Plata, Santiago López Navia), Italia (G. Grilli), Corea (Chul Park) y Brasil (María Augusta Costa Vieira) en número que llegaba a la treintena. La parte académica, bien organizada, se complementó con diversos recorridos turísticos por el viejo Delhi, y la visita al Taj Mahal, magnífico remate de una semana muy fructífera tanto en el aspecto académico como en el de las relaciones entre los participantes. Tan atrayente viaje dio lugar a un libro de Santiago López Navia, El cielo de Delhi, del que reproduzco el siguiente poema:

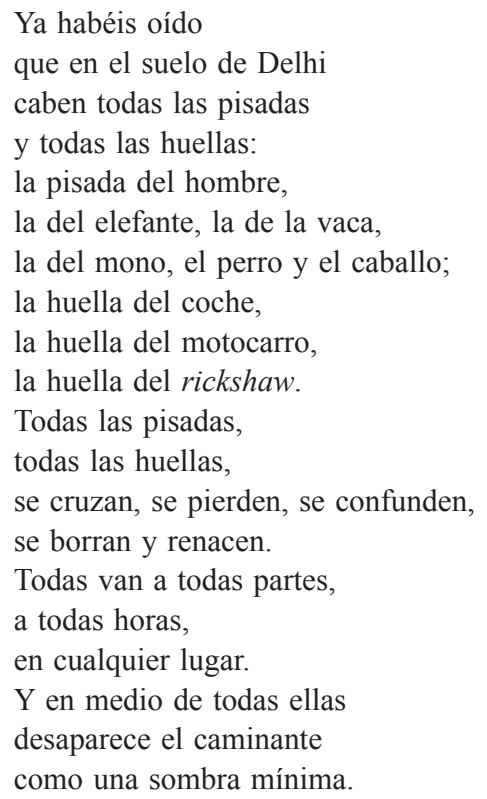


Con la eficaz organización del equipo dirigido por Felipe Pedraza y la coordinación de Pedro Padilla Zagalaz, la Asociación de Cervantistas celebró su XII Coloquio Internacional en el centro cultural «Cueva de Medrano», en Argamasilla de Alba, durante los días 6 a 8 de mayo de 2005. Se convocó, además, como homenaje y tributo de respeto y admiración a José María Casasayas, fallecido en septiembre del año anterior.

Una treintena de investigadores procedentes de los más diversos países -Alemania, Corea, Estados Unidos, Italia, España, Japón, Serbia, Bélgica y Rumanía- presentó sus trabajos organizados en media docena de sesiones que contaron con tres conferencias plenarias a cargo de los profesores López Navia, Pastor Comín y Alfredo Alvar Ezquerra. La primera de ellas evocó la figura intelectual y cervantista de José María Casasayas, la segunda se adentró en el campo de la música cervantina y la tercera, que cerró el coloquio, analizó aspectos históricos de La Mancha de Cervantes. Las sesiones de trabajo se complementaron con dos conciertos de música cervantina y un acto emotivo de homenaje al presidente fallecido.

Es de justicia agradecer la presencia de autoridades representativas de las entidades que apoyaron esta actividad, así como a todos los colegas en Cervantes cuyo entusiasmo y dedicación contribuyó al éxito del coloquio. Se contó asimismo con la presencia de la familia Casasayas -Catalina, Lluis...que vinieron acompañados por el esfuerzo de toda una vida: la traducción del Quijote a su lengua materna que José María había concluido poco antes de fallecer ${ }^{24}$. Los tres volúmenes de esta traducción se presentaron el sábado 7 de mayo, al tiempo que se descubría una placa conmemorativa. La clausura corrió a cargo del representante de la Asociación de Cervantistas, Dr. López Navia, del director del coloquio y del alcalde de Argamasilla, D. José DíazPintado, quien destacó el éxito de organización y participación del coloquio, que se desarrolló, como es habitual en todas las reuniones de esta asociación, en un ambiente de trabajo cordial, favorecedor del encuentro entre los investigadores así como el intercambio de pareceres.

Cinco destacados investigadores (Antonio Bernat Vistarini, Fernando Copello, Ruth Fine, Augustin Redondo, Carlos Romero Muñoz) fueron los responsables de las cinco conferencias plenarias del congreso que la Universidad de Buenos Aires y la Asociación de Cervantistas organizaron ente el 20 y el 23 de septiembre de 2005 en la ciudad bonaerense; fue, sin duda, el congreso más amplio y extenso de cuantos organizó la Asociación de Cervantistas en aquel año; el resultado de ese congreso es un grueso volumen -bellamente impreso- de casi mil páginas.

Alicia Parodi, Julia D'Onofrio y Juan Diego Vila (2006) unieron capacidad de gestión y savoir faire para organizar magníficamente un congreso que reunió a más de un centenar de intervinientes con el propósito de «Volver a leer el Quijote, cuatro siglos más tarde de su primera edición de 1605, retor- 
nar a ese libro controversial desde sus orígenes, engañoso, pícaro, que simulaba una escritura llana pero que resultaba veladamente conceptista, que fue titulado de «laico» pero que cargaba, secretamente, con capas superpuestas de intertextualidad judeo-cristiana, «primera novela moderna «para algunos, y sigilosamente barroca en su compleja trama de significación para otros, fue el cometido primero de tantos eruditos investigadores en esos días» (Parodi, D'Onofrio y Vila, 2006: 19).

El año cervantino se cerró en Jerusalén, donde la Asociación de Cervantistas celebró la última de sus reuniones previstas en el Departamento de Estudios Españoles y Latinoamericanos de la Universidad Hebrea de Jerusalén del 19 al 21 de diciembre de 2005, bajo la rúbrica general de Coloquio Internacional «Cervantes y las religiones».

El Coloquio contó con la presencia de más de sesenta investigadores de primer orden internacional en el ámbito del cervantismo y la cultura y las letras españolas, procedentes de España, Israel, Argentina, Estados Unidos, Puerto Rico, Argelia, Japón, Francia, Canadá, Italia, Grecia, Rusia y Suiza, con sesiones plenarias a cargo de Carlos Alvar, Daniel Eisenberg, Luce López Baralt, Giuseppe Grilli y Carlos Romero; y cuarenta comunicaciones. La labor de Ruth Fine al frente de la comisión organizadora fue de vital importancia para el éxito de la reunión.

Todas estas reuniones científicas dieron lugar a gruesos volúmenes impresos que ahora, gracias al acuerdo con el Centro Virtual del Intituto Cervantes suscrito en 2013, son de libre acceso.

La generosidad de Maria Augusta da Costa Vieira permitió que la Asociación de Cervantistas también figurara en organización del simposio Dom Quixote: 400 anos («El Quijote: 400 años») organizado por la Universidad de São Paulo (Brasil) con la colaboración del Instituto Cervantes en septiembre de 2004; y lo mismo cabe decir de Begoña Lolo, quien ha incorporado siempre la Asociación de Cervantistas a los encuentros organizados por su grupo de investigación, así el Congreso Internacional celebrado entre los días 19 a 21 de octubre de 2005, en la Universidad Autónoma de Madrid y el Círculo de Bellas Artes, sobre Cervantes y el Quijote en la música.

Aquellos retos a que me refería al comienzo de estas líneas fueron conseguidos ampliamente: se constató que la Asociación de Cervantistas no era una individualidad sino la suma complementaria de muchas personas que dan como fruto una colectividad que supo seguir adelante y renovarse, como así se explicitó en las elecciones de 2006, 2009 y 2012; se establecieron nuevos modos y procedimientos de comunicación que la hicieron más fácil con los socios y exoneraron a la entidad de cargas económicas innecesarias; se establecieron acuerdos o principios de acuerdo y colaboración con otras entidades cercanas como el Centro de Estudios Cervantinos - ejemplar y generosa colaboración la suya- la Cervantes Society of America y el Centro Virtual del Instituto Cervantes; también con otras más lejanas, cuyos nombres ya se han referido más arriba; se abrió, en fin, a nuevos hispanistas e hispanismos con numerosas incorporaciones en el registro de socios. 
Todas estas actividades dan ejemplo, además, de una manera de hacer que caracteriza a la Asociación de Cervantistas, sus armas, en el mejor sentido de la expresión: la amistad, la buena y estrecha colaboración entre todos, la responsabilidad en el trabajo y un ambiente de franca camaradería. Eso permitió -y sigue permitiendo- colaborar con entidades y personas muy distintas, desde nuestras más cercanas Oviedo, Argamasilla y Alcalá de Henares, hasta las más lejanas, en la distancia, que no en el afecto, Delhi, Buenos Aires y Jerusalén. Et sic de coeteris.

La Asociación de Cervantistas se afana en mantener sus principios estatutarios fundamentales, y lo hace no en función de conmemoraciones puntuales -sin desdeñarlas, por supuesto-, sino en todo tiempo y circunstancias; este es su principio de actuación básico: en 2004, en 2005, y siempre.

\subsection{Un grande escrutinio: el patrimonio bibliográfico de la Asociación de Cervantistas ${ }^{25}$}

Desde hace unos años se venía gestando entre el Centro Virtual Cervantes y la Asociación de Cervantistas la creación de un espacio -un ciberespacio, en realidad- que diera cabida a las publicaciones de la Asociación. Los desvelos del anterior presidente, José Montero Reguera (algunos de los ejemplares que pueden consultarse en la Red proceden de su colección personal, según reza en la misma página) y de la nueva junta directiva presidida por José Manuel Lucía Megías han conseguido que, cumplidos los veinticinco años desde que «aquellos quince aguerridos cervantistas en febrero de 1988» (Casasayas, BIAC, 1989) firmaran el acta fundacional, el Cervantismo pueda congratularse de contar con este portal $(<$ cve.cervantes. es/literatura/cervantistas $>$ ) que acoge las aportaciones de veintiún libros de la Asociación de Cervantistas que responden a otros tantos encuentros de especialistas (1988-2009) más los tres números del Boletín de la Asociación publicados entre 2004 y 2007. Si la Asociación «permitió la unión, a nivel internacional, de los cervantistas, que estaban disgregados hasta entonces en sus esfuerzos» (José Carlos de Torres Martínez, uno de los socios fundadores, en «La empresa romántica de la Asociación de Cervantistas», XII CIAC, 53), ahora esta nueva «asociación» aúna en un único lugar los trabajos de estos esforzados investigadores.

Tamaña «empresa»-y «romántica»-, sin duda. Todas las publicaciones de los congresos y coloquios cervantinos que a día de hoy han visto la luz, más algunos libros de otros encuentros de temática cervantina. Quedaron en la memoria de otros las aportaciones del primero de los congresos, celebrado en Almagro en 1991, y las de los tres coloquios consecutivos celebrados en Alcalá de Henares, Montilla y Castro del Río entre 1994 y 1996. 
Hasta ahora no era fácil acceder a la colección. A la colección completa, al menos. Conocida es la difusión generalmente reducida de los libros resultantes de los congresos, las más de las veces de volumen impracticable, amén de la diseminación de unos y otros resultados en editoriales de aquí y de allí, y sin indicación, más allá del subtítulo, cuando lo tienen, de la serie o colección a la que en espíritu pertenecen. Además, la publicación de tres de ellos en revistas especializadas (en Annali dell'Istituto Universitario Orientale di Napoli los resultados del II CINDAC; Cervantes: Bulletin of the Cervantes Society of America, los del VII CIAC; y Anales Cervantinos, con los del IX $C I A C$ ) dificultaba localizarlos junto con sus hermanos editados en formato libro, porque en las nóminas de catálogos y recursos bibliográficos que daban la entrada por el título de la revista quedaban difuminados entonces cuáles eran los contenidos que allí se presentaban. Con la digitalización y publicación en línea abierta de dos de estas publicaciones, más alguno de los libros de los congresos internacionales (III CINDAC) el Cervantismo resultante de los encuentros de la Asociación comenzó a abrirse paso en la Red. Pero la dispersión, digital ahora, seguía siendo un lastre. El nuevo repositorio web, ordenado y de fácil acceso, permite la consulta de cada una de las aportaciones de cada autor por separado.

En su totalidad, la colección resulta abrumadora. Para los amantes de las cifras, que alguno queda entre los amigos de Cervantes, he contabilizado mil ciento veinticuatro trabajos de seiscientos cuarenta cervantistas en casi unas -agárrense- quince mil páginas. Y aunque, como dice el refrán popular, no están todos los que fueron, sí que fueron todos los que están. Las bajas entre la celebración y la publicación de actas han sido pocas, si bien es cierto que no todas pueden responder al fiel reflejo de lo que se compartió en aquellos días.

Estas gigantescas cifras hablan de una extraordinaria vitalidad para una asociación que, según nuestros cánones actuales, sigue siendo joven cuando acaba de cumplir sus veinticinco años. Habría que ver la expresión de aquel enemigo del Cervantismo que en junio de 1862 recelaba en las páginas de $E l$ Contemporáneo: «A ser cierta la creación de una sociedad cervántica con su periódico trimestral en que solo se hablase de Cervantes, acabarían muchos por aborrecer a Cervantes y por fastidiarse con el Quijote». A las puertas del IV Centenario de la segunda parte del Quijote parece que ese aborrecimiento aún no ha llegado. Ni llegará.

Seiscientos cuarenta investigadores unidos en torno al autor del Quijote. De estos cervantistas que ha ido uniendo el paso de los años de la Asociación, algo más de la mitad procedían de universidades españolas o eran de origen español, y poco a poco los encuentros, y sus libros, fueron abriéndose a colaboradores de todo el mundo. La ampliación del marco geográfico de celebración tras los primeros coloquios supuso un notable cambio de perspectiva en este sentido, que se va acentuando con los años, a medida que el mundo se hace más pequeño y la Asociación de Cervantistas más grande. 
Se dan cita en este ingente número de páginas los autores ya consagrados en la materia cervantina, otros ajenos al mundo filológico -los menos, cierto es- y un creciente grupo de «jóvenes estudiosos para reverdecer el cervantismo» (Torres Martínez, 2008: 63). Muchos de los libros de los primeros y de las primeras publicaciones de los segundos han nacido, incluso se han ensayado, en las páginas de estas publicaciones.

La mayoría de estos cervantistas (quinientos treinta y ocho) colaboraron en uno solo de los libros publicados. Del reincidente centenar restante se destacan desmarcados del pelotón algunos sin los que parece no podría celebrarse ya ningún encuentro cervantino: el inalcanzable -en número y calidadSantiago López Navia, que gana a todos por varias más y por la mano, que estuvo prácticamente en todos los encuentros (su nombre figura al frente de dieciocho de los veintiún libros) seguido, no de tan lejos, por el club de autores que han llegado y superado la decena de resultados publicados de estos encuentros (Frances Luttikhuizen, Kenji Inamoto, José Manuel Martín Morán y Carlos Mata Induráin) y los que se acercan peligrosamente (Anthony Close, Heinz-Peter Endress, Aurelio González, Steven Hutchinson, Alicia Parodi de Geltmann, María Augusta da Costa Vieira, Ruth Fine, Giuseppe Grilli, Isabel Lozano-Renieblas, Jesús González Maestro, Eduardo Urbina, Chul Park, José Montero Reguera, Carlos Romero Muñoz, Juan Manuel Villanueva Fernández).

Pero no solo de cifras vive el cervantista. Si hay alguien que está en todos, paradójicamente casi sin estar en la nómina de autores que se entresaca de los índices, es José María Casasayas, presidente de la Asociación hasta su muerte en 2004 y «el mayor encantador de los muchos que tienen estos libros». Está detrás de cada encuentro y al frente de las primeras publicaciones. «Abogado, bibliófilo y, sobre todo, amigo de Cervantes y de todos los cervantistas» (Chul Park, 2005), «hombre de empresa, decidido, tenaz, generoso y altruista» (Pedraza Jiménez, 2008: 13), fue el «el verdadero motor» (Bernat Vistarini, 1998: «Presentación», X), de estas reuniones, quien «consiguió movilizar las mesnadas, organizar la tropa y prever las ayudas de costas necesarias» siendo «responsable de que todo llegara a buen término» (Bernat Vistarini, 2001b: IX). Alentó, además, el interés de toda la Asociación en internacionalizar los encuentros; se enorgullecía de los que desde fuera acudían a los encuentros manchegos al mismo tiempo que hizo hincapié y removió conciencias, instituciones y correos para llegar a Seúl o Nueva Delhi. Las publicaciones de la Asociación recogen (además de las presentaciones de los tres primeros CIAC) un trabajo en el $I X C I A C$. Su nombre, de otro lado, está en todas las presentaciones, en todos los agradecimientos y en todos los recuerdos.

En cuanto al contenido de las publicaciones se comprenderá que resulte una tarea quijotesca, y aun más, dar una idea global del que encontramos en esta colección, «dando de estos libros uno a uno para ver de qué trataban». Baste decir que ninguno es merecedor de castigo de fuego. Claro que hay un agente catalizador que dota a la colección de la homogeneidad de la que suelen carecer las actas de congresos de gran formato. Todo en ellos es Cer- 
vantes. Así, la colección da buena cuenta de la función asumida por la Asociación de Cervantistas recogida en sus estatutos.

Pero no es solo el contenido lo que aglutina estos libros como colección. Lo son también sus autores, lo son también los lugares que sirvieron de encuentro, lo es, sin duda, la transmisión primera de estas enseñanzas, de viva voz, y compartidas en tiempo y espacio. Porque fue esta finalidad, la de la colaboración, la que inspiró la creación de la Asociación, bautizada con toda la prudente intención de que fuimos capaces no con el apelativo de una asociación «cervantina» más entre las muchas ya existentes, sino como «la única» asociación «de Cervantistas». (Casasayas, BIAC, 1989).

La presentación actual, escrita, y ahora del papel a la pantalla de ordenador, es el resultado madurado de un continuo diálogo entre especialistas. Así

[...] quien abra estas Actas verá, sobre el esfuerzo devoto y el notable gasto de energía interpretativa de un puñado de seres peregrinos, la progresión del diálogo que inició Cervantes llevada a máxima intensidad. Es la responsabilidad aquí asumida: perseverar en el viejo sueño del diálogo» (Bernat Vistarini, 1998: «Presentación», X).

Aun ese grupo que figura al final de la nómina de libros con la etiqueta de «Otras publicaciones», la mayoría en torno a un tema propuesto como núcleo de reflexión, responde a la materialización de un encuentro entre colegas. Así, aunque resulte una perogrullada, cada una de estas publicaciones es la plasmación de una reunión científica, y física, que tuvo lugar uno, dos y hasta tres años antes, que hizo pasar a sus editores días y noches de claro en claro y de turbio en turbio a la espera de los trabajos de los asistentes, y que mantienen algo de ese sabor circunstancial en los preámbulos y prólogos (con sus recuerdos de la imborrable imagen de algunos lugares, de la calidez de las fechas, de la intensidad de las jornadas, de lo animado de las cenas, de la dadivosidad de las instituciones y la generosidad de los organizadores) que dan paso al valor atemporal de las contribuciones que siguen. Igual que cada encuentro espolea las ganas del reencuentro, cada uno de estos libros publicados acaba llamando al siguiente en un diálogo continuado en el -distante, eso sí- tiempo. Todos se cierran con el deseo de gozar en el futuro de nuevos encuentros con nuestros amigos ponentes del Coloquio, en los cuales sin duda recordaremos los inolvidables momentos que pasamos aquel día en que hablamos de Cervantes allá en un lugar de Corea de cuyo nombre no quiero acordarme (Chul Park, IX CIAC, «Presentación», iii).

Obviedad del mismo calado es llamar la atención sobre lo que supone cada encuentro de investigador como trampolín de las aportaciones que allí se presentan, cuando uno, con el reposo del tiempo entre encuentro y publicación, reestructura, reinterpreta -o escribe en su totalidad- su primera visión y perspectiva al calor del diálogo. Cada uno es, que duda cabe, autor de la contribución que sigue a su nombre. Pero no es menos cierto que muchas de estas se han perfilado al compartirla con los miembros de la Asociación. Al menos, se habrán confirmado en ellas mismas. Lo que los encuentros significaron de Cervantismo in fieri llega después a estos textos a un clic del ratón 
reactualizados e inamovibles. Y es esto lo que queda hoy como legado de la Asociación. Verba volant, scripta manent.

Decía Azorín del Cervantismo, aunque en un sentido diferente (él trataba de establecer dos genealogías interpretativas para acercarse al autor), que a partir de este punto de partida se trazaban dos caminos: «uno es el de la erudición; otro, el de la vida» (Con permiso de los cervantistas, Madrid: Biblioteca Nueva, 1947, prólogo, 5), el primero, áspero, consagrado al papel, el segundo, igualmente acerbo, imaginativo, a la sensación. Parafraseando aquella presentación de ánimo polémico, es la vida de aquellos días de encuentros cervantinos - no exenta de erudición, claro- la que da paso a este patrimonio bibliográfico - sin falta de vida, por supuesto-. El mismo Azorín acababa llamando a la conciliación. Vida y erudición. Amistad y Filología. Cervantismo:

Quien no estuvo podrá así [leyendo estas actas] reconstruir el ambiente, cálido y cordial, de aquellas jornadas (Grilli (ed.), 1995: «Pórtico», 5).

[...] estos congresos no terminan el día de la clausura; puedo dar fe con mi experiencia (Carmen Agulló Vives, reseñando el $V$ CINDAC, BAC, 2004, I-1, 45-9).

El coloquio no ha quedado solo en eruditas aportaciones, sino que ha permitido al tiempo el intercambio de pareceres e ideas, la amena conversación, el reencuentro de viejos amigos y la celebración de un coloquio paralelo en lugares menos académicos... (Montero Reguera, 2004b: 48).

[...] nada más resta sino la promesa de que estas páginas fueron el intento de celebrar, gracias al Quijote, el triunfo de nuestra amistad (Parodi, D’Onofrio y Vila (ed.), 2006: «Introducción», 24).

\section{De congresos y coloquios, encuentros del mesmo linaje (II-VII CINDAC/ I-III; VII-XII CIAC)}

La Asociación de Cervantistas ha parcelado sus encuentros tal y como en la primera Asamblea presidida por Alberto Sánchez se acuerda en «la organización de Congresos Internacionales Cervantinos en la forma, la periodicidad, la localización y las demás circunstancias que oportunamente se decidirán», y al tiempo unas «jornadas» cervantinas que han dado en los coloquios internacionales (presentación de José Manuel Lucía en el portal de «Cervantistas» del Centro Virtual Cervantes). Ocho congresos y doce coloquios celebrados y seis - de momento, a falta del volumen del último- y nueve publicaciones. Un recorrido por los avatares de organización de estos congresos, para reconstruir la vida que late tras estas páginas, está en el trabajo de José Carlos de Torres Martínez - uno de los socios fundadores- en el volumen Con los pies en la tierra (XII CIAC, «La empresa romántica de la Asociación de Cervantistas»).

La primera de las publicaciones de la Asociación fue el resultado de un continuo esfuerzo. Y algo desesperante para el que fuera presidente de la 
Asociación, José María Casasayas. Costó arrancar. Aquella publicación del $I$ CIAC (1990) salió dos años después de su celebración (1988) con algunas bajas entre los asistentes que allí estuvieron. El mismo Casasayas escudaba el conjunto resultante en la propia naturaleza de su génesis, el libro de actas no era sino el fiel reflejo de lo que allí pasó: «Más de un lector conspicuo notará, en principio, que hay mucha desigualdad en la calidad de los trabajos presentados y que acaso alguno de ellos bien podía haber sido excusado» (Casasayas, I CIAC: 7). No será tanta la desigualdad -o no seré yo tan «conspicuo»-, aunque bien es cierto que en las posteriores se fue produciendo, casi como en un filtro inconsciente impuesto por aquello que se convierte en tradición, una progresiva homogeneización de contenidos, alcance y tono. Poco después aparece la segunda, «más nutrida» (Casasayas, II CIAC: nota preliminar, 7) que, aun celebrándose en Alcalá de Henares, como el anterior y los siguientes, ya daba cuenta de la dispersión geográfica de sus contribuyentes, en un continuo crescendo. Casasayas, orgulloso, podía escribir al frente del libro:

doce han venido de USA y entre los restantes hay cuatro que provienen de Italia, tres de Inglaterra, dos de Argentina y una de China, Japón, México, Polonia y Yugoslavia. Nuestro mayor deseo sería que estos Coloquios fueran el exponente más claro del afán de colaboración entre los cervantistas de todo el mundo» (Casasayas: II CIAC, nota preliminar, 7).

Tras el tercero de los coloquios, hay un silencio notable en las publicaciones de la Asociación; mientras Grilli trabajaba en las actas del II CINDAC -también el primero de ellos quedó en el aire y la memoria- los coloquios entre 1994 y 1996 no vieron versión impresa. Casasayas cedería el testigo como editor, y a partir del séptimo de los coloquios se recuperó el esfuerzo por dejar legado escrito de los encuentros cervantinos, aunque no sin dificultad: el VII CIAC lograría colarse fragmentariamente, en la publicación seriada Cervantes, de la Cervantes Society of America, prescindiendo prácticamente de la mitad de las contribuciones orales. «De esta manera, el VII Coloquio Internacional de la Asociación de Cervantistas ganó en tradición oral lo que ahora, por desgracia, pierde en transmisión escrita» (Fernández de Cano y Martín, VII CIAC: «Prólogo», 4). De manera similar, el VIII CIAC, se diversificó en dos secciones, la que recoge el Centro Virtual Cervantes en el volumen publicado en 1999 y una segunda que apareció en el número de otoño de 1999 de la revista americana Cervantes, que dio cabida a «una pequeña muestra de los trabajos presentados», once comunicaciones y una ponencia plenaria, disponible igualmente en la Red,

en un volumen que ha de ser considerado como un complemento indispensable del que el lector tiene hoy entre sus manos, máxime para aquellos que deseen contemplar una visión amplia, rigurosa y actualizada del status quaestionis del cervantismo mundial (Fernández de Cano y Marín, VIII CIAC: «A guisa de preámbulo»,16). 
Rozando el cambio de milenio, las imprentas cercanas a la Asociación vuelven a funcionar con continuada frecuencia y sus publicaciones se convierten en asiduos compañeros de viaje de todo lo que toca al autor del Quijote. En torno a 2004-2005, cumpliendo la mayoría de edad la Asociación y calentando motores para el IV Centenario que se venía encima, hay una enorme concentración de la actividad: entre los encuentros que se estaban celebrando, preparando, y los anteriores que estaban tomando cuerpo en publicaciones, la labor bibliográfica de la Asociación se convierte en rutina. Esta fecha viene marcada por la muerte de José María Casasayas, siendo aún presidente. Su voz, diligente e implicada de las primeras publicaciones, había dado paso a otros cervantistas en las siguientes, que agradecieron y elogiaron su labor, tiñendo a partir de 2004 sus fervientes aplausos con sentidos recuerdos.

Desde antes, y en buena parte por los esfuerzos continuados de Casasayas, la Asociación y sus publicaciones habían alcanzado lejanos lugares del mundo, trazando un romántico recorrido vital por los avatares de la propia biografía cervantina y quijotesca.

La dispersión geográfica de los encuentros y editorial de sus publicaciones se fue acrecentando, lo que se traduce en el aumento de enfoques diferentes y puntos de interés, fundamentalmente en el caso de los congresos internacionales, en cuya periodicidad trienal ha impuesto un movimiento casi pendular en el destino de los encuentros de los congresos, que han visto desfilar a los cervantistas por Nápoles, Menorca, Lepanto, Lisboa, Alcalá de Henares y Münster. El último los reunió en Oviedo y el siguiente los llevará, por primera vez, al otro lado del Atlántico, a Brasil.

Los coloquios quedaron en el ambiente manchego y sus cercanías de Alcalá de Henares (los cuatro primeros), Montilla, Castro del Río, Argamasilla (VII y XII), El Toboso y Villanueva de los Infantes.

Cuando el sonado evento tiene por sede algún lugar de La Mancha, las adehalas anejas al honor de participar activamente en la organización de un coloquio cervantista traen aparejado un manojo de hondas satisfacciones [...] del trato directo con las personas e instituciones manchegas, siempre dispuestas a hospedar con agasajo al visitante, cuanto más si se trata de un apasionado recolector de semblanzas, anécdotas y estampas quijotescas» (Fernández Cano y Martín, VIII CIAC: «A guisa de preámbulo», 13).

El $X$ CIAC celebrado en Roma sirvió de trampolín para el XI, que llevó a la Asociación a Seúl (para los amantes de los números, a casi diez mil kilómetros de casa, dejando Alcalá de Henares equidistante del otro encuentro más alejado, a otros tantos, en Buenos Aires). Este coloquio, «agradable y enriquecedor» de enorme éxito y su publicación subsiguiente marcaron todo un hito en las obras de la Asociación.

Fue también empeño de Casasayas, que consiguió llevar «al Asia a aquel que ni el emperador de la China pudo convencer hace ya cuatrocientos años»» (Chul Park, XI CIAC: «In memoriam José María Casasayas»). A esta apertu- 
ra se sumaron los encuentros también de Nueva Delhi y Jerusalén, cuyos resultados impresos se encuentran bajo el membrete de «Otras publicaciones».

Con cierto sesgo que imponen algunos de estos lugares (destaca la «pujanza del hispanismo coreano» del $X I C I A C)$ y alguna de las temáticas propuestas ( $V C I N D A C$ en torno al Persiles; el XCIAC sobre las relaciones entre Cervantes e Italia, y el XII CIAC con «una primera y primordial sección a la tierra de don Quijote», Pedraza Jiménez, «Un nuevo coloquio, no un coloquio más»), tan alto número de contribuciones de todo el orbe hispanista no podía sino traducirse en una evolución paralela a la de los estudios hispánicos del último cuarto de siglo.

Siendo el Quijote líder indiscutible de los contenidos, desde los inicios «es de notar la tendencia creciente de valorar cada día más sus obras menos estudiadas, como son el Persiles y Sigismunda, o su teatro, o su poesía» (Casasayas: III CIAC, «Nota preliminar», 7). La publicación del $V$ CINDAC, coordinado por Villar Lecumberri, es hoy día, y será en mucho tiempo, la más nutrida de las obras dedicadas a la última novela de Cervantes. De los primeros congresos los propios editores trataron de extraer, a posteriori, cierto sentido de conjunto; si en el libro de actas del II CINDAC Giuseppe Grilli ponía el énfasis de sus contribuciones en el análisis de la literatura de entretenimiento, en el III Bernat Vistarini lo hacía en la evaluación del personaje cervantino.

La oportunidad de la circunstancia que supone para muchos especialistas la celebración de cualquiera de estos eventos (recordemos que la mayor parte de ellos solo han participado en uno de la veintena) hace que a estos se hayan acercado no solo especialistas de Cervantes, sino los que, desde otros campos, se han visto animados a trabajar sobre su vida y obra quizás a raíz del anuncio del encuentro. De ahí que una de las aperturas temáticas que pueden destacarse en el conjunto es la presencia cada vez mayor de estudios comparatistas, de ecos e influencias de Cervantes en otras épocas, autores, disciplinas y formatos, esta última vertiente impuesta por el tiempo, aún tímida, pero notable: cada vez es mayor el volumen dedicado a estas nuevas visiones de Cervantes en la modernidad.

Completará muy pronto el patrimonio bibliográfico de los CINDAC la publicación de los resultados del VIII de estos, hoy en prensa, editado por Emilio Martínez Mata y María Fernández Ferreiro con el título de Comentarios a Cervantes: Actas selectas del VIII Congreso Internacional de la Asociación de Cervantistas (Madrid: Fundación María Cristina Masaveu Peterson, 2014).

\section{Un breve Boletín y el estado del cervantismo (BIAC, 1989; BAC, 2004 y 2005-2007)}

Junto a los libros resultados de estos encuentros, la Asociación contaba con un pequeño órgano de difusión, el Boletín de la Asociación de Cervantistas $(B A C)$, que nace con carácter bianual, naturaleza que solo tuvo en el año de 
2004. «Constituyéndose, no tanto en una revista sobre Miguel de Cervantes (Anales Cervantinos y Cervantes cumplen sobradamente esta función), sino sobre el Cervantismo, de manera paralela a otras publicaciones similares» (Montero Reguera, 2004c: 5) y concebido «entre dos horas amargas: los fallecimientos de don Alberto Sánchez y José María Casasayas, primer y último presidente de la Asociación de Cervantistas» (Montero Reguera, 2004c: 6), solo contó con otro número ese mismo año y un segundo número para el bienio 2005-2007.

Es heredero del de 1989 promovido por José María Casasayas que, con el título de Boletín Informativo de la Asociación de Cervantistas (BIAC), pretendía dar noticia del cervantismo del tiempo:

A todos los miembros, pues, de esta $\mathrm{AC}$ va dirigido este primer número del Boletín Informativo, al que seguirán, conforme las necesidades de la $\mathrm{AC}$ lo requieran, otros, con la triple finalidad de informar, de servir de nexo entre los asociados y de recabar de todos la colaboración necesaria para el buen cumplimiento de los fines de la AC: en forma de prestación personal, según las posibilidades de cada uno, o, cuando no, mediante la comunicación de sugestiones, de ideas nuevas, de soluciones a los problemas que se plantean (Casasayas: BIAC, 1989).

Planteamiento útil, sin duda, que cuenta con las noticias de las asambleas, programas de los coloquios, balance económico de la asociación, registro de asociados, noticias varias y un útil «Boletín bibliográfico cervantino».

Parece ser, a tenor de las opiniones recibidas, que lo que ha despertado más interés entre los miembros de la $A C$ ha sido este Boletín Bibliográfico Cervantino, que tiene que consistir, como su mismo nombre indica, en una publicación periódica que vaya registrando todos los estudios cervantinos que se publiquen y dé sobre ellos una información (no crítica, sino meramente expositiva) acerca de su contenido (Casasayas: BIAC, 1989, 26).

La nueva versión de 2004 se estructuraba en un bloque de «Clásicos y Modernos», que recogía páginas del Cervantismo de todos los tiempos; "Galería de cervantistas ilustres», reseñas de figuras de especial interés; «De crítica cervantina», reseñas de libros cervantinos recientes y de las publicaciones de los socios (pedía colaboración de estos para que dieran cuenta de sus publicaciones); «La dama del alba» para panegíricos in memoriam (Ermanno Caldera, Lázaro Carreter, Porqueras Mayo, en el I-1; Casasayas, Meregalli y Geoffrey Stagg en el I-2; Soledad Carrasco Urgoiti en el II, 2005); «Crónica cervantina»y «Noticiero cervantista», sobre las actividades de la Asociación. Herramienta enormemente útil que ha tenido que ceder su empuje ante el inexorable avance de los nuevos tiempos y la imperiosa necesidad de satisfacción momentánea de la información, cediendo su lugar, oficiosamente, a otros cauces. El blog El donoso escrutinio <eldonosoescrutinio. wordpress.com>, que debemos al esforzado brazo de José Manuel Lucía, actual presidente, y a Adrián J. Sáez, cumple en estos días esta función. 


\section{Las otras publicaciones de la asociación}

Concentrados en torno a otros encuentros, generalmente con una disposición temática muy marcada, la Asociación de Cervantistas publicó otros seis libros una vez consolidada como asociación (2000-2011).

El primero que abre este apartado es el de Desviaciones lúdicas en la crítica cervantina, editado por Antonio Bernat Vistarini y José María Casasayas, sin duda el más «disparatado»-y quizá «arrogante»- de toda la colección. Siendo el hermano pequeño del III CINDAC, compartió con él espacio y tiempo, y a muchos de sus colaboradores. Agrupó dos trabajos en memoria de Maurice Molho, que fue uno de los fundadores del proyecto, además de tres ponencias y treinta comunicaciones. El encuentro fue de lo más variopinto: etiquetados bajo el rótulo de Locos Amenos, los allí reunidos celebraron su primer «convivio» - por desgracia sin continuidad, al menos pública que se sepa, hasta el momento- de «locos amenos», amenos y amigos (es el libro en el que se produce mayor concentración de cervantistas presentes en otros encuentros de la asociación), que hablaron en esos días sobre «cervantismos descarriados» y otros márgenes de la crítica en la «ínsula» de Menorca, en un volumen exquisito y variado. Concebido en una amenísima cena en Nápoles en el marco del II CINDAC, tardó en materializarse la propuesta del comité, formado por James Iffland, José Manuel Martín Morán, Maurice Molho y Alan Smith, al que se le añadió desde la mesa contigua José María Casasayas. Todos «indudablemente, locos. Si, además, amenos, tanto mejor» («Proemio», 14). Trataron de evitar «a toda costa [...] justamente un mezquino espíritu punitivo, señalando con un dedo descalificador a los "descarriados"», resultando un «librito» - el diminutivo es por lo entrañable, no por el volumenenormemente jugoso. Y loco, y ameno.

El siguiente de estos libros fue una propuesta que volvió a hacer viajar a los cervantistas a los confines de la tierra. El Quijote en Buenos Aires: lecturas cervantinas en el Cuarto Centenario (editado por Alicia Parodi, Julia D’Onofrio y Juan Diego Vila) reúne las aportaciones realizadas en el encuentro celebrado en la Universidad de Buenos Aires, con cinco conferencias plenarias, once paneles semiplenarios y comunicaciones, que se reparten entre las dedicadas al Quijote («Lecturas del Quijote» (44); «El Quijote en la literatura española» (13) y «El Quijote en la Literatura Latinoamericana» (11) y otras obras cervantinas: «Novelas ejemplares» (5), «Persiles» (4), «Viaje del Parnaso» (1) y «Teatro» (12). La tónica vuelve a ser la del leit motiv de la Asociación:

La convocatoria para la ciudad de Buenos Aires, verdadera terra australis incognita para tantos peregrinantes del encuentro, tuvo como motor primero la fuerza de la amistad. Aquella que nos unía en grados diversos a todos nosotros y, fundamentalmente, aquella que se generaba en el amor al libro convocante (Parodi: «Introducción»).

El coloquio internacional celebrado en Oviedo del 27 al 29 de octubre de 2004 también tuvo su versión impresa en 2007 a cargo de Emilio Martínez 
Mata, Cervantes y el Quijote, ofreciendo una contribución para el apartado de la figura de «Cervantes», doce dedicada concretamente a la obra del Quijote, catorce sobre «Recepción e influencia del Quijote» y una sobre «El Quijote de Avellaneda». Coincidieron en estos días ovetenses los «grandes maestros de cervantismo con jóvenes investigadores. En esta convivencia tan fructífera con los consagrados, los jóvenes respondieron a lo que se esperaba de ellos, demostrando ser capaces de continuar con la tradición del cervantismo» (reseña contenida en el $B A C, 2005-07:$ 7-8).

Acostumbrados ya a los periplos por tierras peregrinas, en 2005 la Asociación se embarcó camino al International Centre de Nueva Delhi para la celebración de un encuentro sobre Miguel de Cervantes los días 31 de enero, 1 y 2 de febrero, editado por Vibha Maurya e Ignacio Arellano, en un volumen con veintiséis nuevas aportaciones que se reparten en cinco núcleos temáticos: «Reflections on Don Quixote» (4), «Contextualising Don Quixote» (5), «Thematics in Don Quixote» (6), «Reception of Don Quixote» (7), «Visual Representation of Don Quixote» (4). Por primera vez las publicaciones de la Asociación abandonan la hegemonía de la lengua española, para hacer de otra, también, la lengua de Cervantes. Nuevas perspectivas para la crítica cervantina, que da voz en este número a destacados investigadores generalmente alejados de estos fastos.

Difícil fue el siguiente reto: la Asociación afrontó en los límites finales del IV Centenario, al fin de diciembre y como broche final a la sucesión de eventos, la organización de un nuevo coloquio conjuntamente con el Departamento de Estudios Españoles de la Universidad Hebrea de Jerusalén, en aquel «marco excepcional» de aquella ciudad, entre el 19 y 21 de diciembre de 2005 en torno a un tema peliagudo, "por las asperezas y a las divergencias que suscita» (14): Cervantes y la Religión. Resultado de este fue el interesante título de Cervantes y las religiones, coordinado por Ruth Fine y Santiago López Navia y publicado en Iberoamericana-Vervuert en 2008 con treinta y nueve trabajos: cuatro conferencias plenarias y otros trabajos repartidos bajo las etiquetas de «Cervantes y el catolicismo» (7), «Cervantes, el erasmismo y el protestantismo» (3), «Cervantes y el Islam» (4), «Cervantes, el judaísmo y los conversos» (6), «La religión en el Quijote y su recepción» (3), «Otras visiones del tratamiento de las religiones en la obra de Cervantes» (5), «Cervantes, otros temas» (7).

El último vástago del patrimonio bibliográfico de la Asociación de Cervantistas es el libro editado por Carmen Rivero Iglesias, Ortodoxia y heterodoxia en Cervantes, que recoge las aportaciones de las sesiones paralelas al VII CINDAC celebrado en Münster y agrupadas a partir del tema que lleva por título:

Si entendemos por heterodoxia la disconformidad con doctrinas o prácticas generalmente admitidas en una determinada época y por ortodoxia su concepto opuesto, la multiplicidad de discursos en la obra del autor áureo nos brinda la posibilidad de abordar esta cuestión desde numerosas perspectivas» (Rivero: «Introducción», 11). 
El conjunto de estudios que ofrece suman un total de veintiocho trabajos repartidos en tres bloques: «Religiosa / Política / Social» (13), «Poética / Retórica / Literaria» (7) y «Recepción» (8).

\section{Pero falta mucho por andar todavía (José María Casasayas, BIAC, 1989)}

Este sucinto - «sucintísimo» análisis a tenor del volumen considerado- de los «fervores monomaníacos del Cervantismo», como nos llamó una vez José María de Pereda, dan buena cuenta de que no es necesario que se agote este movimiento para que el «Quijote vuelva a reinar en la patria literatura». Aquellas contribuciones, algunas de las que podrían haber quedado sepultadas tras el fragor de los encuentros, han vuelto más vivas que nunca gracias a las maravillas de la modernidad. Un simple vistazo a estas da cuenta de la vitalidad mantenida de los estudios cervantinos, son «el mejor cuadro» -y parafraseo a Bernat Vistarini en la presentación del III CINDAC- «y punto de partida de lo que queda por decir». Buen augurio para el Centenario que viene. Bernat Vistarini bromeaba en el preámbulo de la publicación del $I I I$ $C I N D A C$ diciendo que ante la abrumadora superior inteligencia y complejidad de la obra que leemos de continuo buscando nuevas pistas -el Quijote-para nuestros trabajos, acabamos haciendo congresos. Así sea. Celebrándolos... y publicándolos. Queden pues, libres del fuego, siendo «libros de entretenimiento» -y algo más- «sin perjuicio de tercero»: «El hallazgo de ahora, estimula para el hallazgo de mañana» (Azorín, Con permiso de los cervantistas: 5).

\section{PROYECTOS Y PERSPECTIVAS DE FUTURO DE LA ASOCIACIÓN DE CERVANTISTAS ${ }^{26}$}

1. Las asociaciones científicas en todo el mundo están abocadas en la Sociedad de la Información y del Conocimiento a replantearse sus fines y los medios que han puesto en marcha para conseguirlos, ya que nos encontramos en un escenario bien diferente al que se vivía en el momento de su creación: 50 años para la Asociación Internacional de Hispanistas (AIH), 30 años de la Asociación Internacional Siglo de Oro (AISO) o los 25 años de nuestra Asociación de Cervantistas, por solo citar las tres asociaciones más vinculadas a nuestro ámbito, cuyos congresos internacionales se desarrollan de manera consecutiva.

El artículo 3 de los nuevos Estatutos de la Asociación de Cervantistas, aprobados en el año 2009, establece claramente sus fines: «Esta asociación existe para fomentar el contacto entre todos sus socios así como la consecución de sus fines, que consisten en el estudio científico de la vida y obra de

26. Por José Manuel Lucía Megías. 
Miguel de Cervantes y la divulgación de los resultados de sus investigaciones», y en el siguiente artículo, se concretan las cuatro actuaciones fundamentales que le permiten su cumplimiento:

a) publicar y poner al día una lista detallada de todos los socios;

b) informar a los socios de la marcha de la asociación mediante la difusión periódica de circulares durante el período entre un congreso y el siguiente;

c) organizar un congreso cada tres años, cuya lengua oficial será el español;

d) colaborar con las asociaciones nacionales e internacionales de índole semejante.

La necesidad de crear órganos y espacios de comunicación entre una comunidad científica interesada en un mismo ámbito de estudio, que permitiera el diálogo entre los estudiosos y el conocimiento de los temas y metodologías desarrollados en los últimos años, parecía ser la razón de ser de la creación y el desarrollo de nuestras asociaciones científicas. Las escasas comunicaciones entre centros de investigación, la dificultad para el conocimiento y acceso a la bibliografía especializada, la lentitud en el proceso de difusión de las nuevas aportaciones hacían más que necesaria la creación de boletines bibliográficos e informativos, la convocatoria de congresos internacionales, y la publicación de las correspondientes actas, que se convertían en lectura obligatoria, radiografía de una disciplina, pues en ellas se dejaba constancia de lo realizado en los años precedentes así como de las líneas y proyectos abiertos para el futuro, que tendrían su difusión en el siguiente congreso. Pero en la actualidad, en el triunfo de la conocida como Sociedad de la Información y del Conocimiento, donde los espacios de difusión se han multiplicado y las distancias casi han desparecido, donde la comunicación de los expertos en una materia es continua, se hace necesario replantear las funciones de nuestras asociaciones, los servicios que pueden dar a sus socios, que justifiquen su existencia, más allá de la inercia de actividades y modelos heredados del pasado. Ya tendremos ocasión de volver sobre este asunto.

2. Por su parte, la Asociación de Cervantistas ha tenido que hacer frente en los últimos diez años a un proceso de reestructuración y de reorganización, a raíz de la muerte inesperada de José M. ${ }^{a}$ Casasayas el 27 de septiembre de 2004, que había sido uno de sus mentores, apoyado y aconsejado por la sabiduría de Alberto Sánchez, como se aprecia por la correspondencia mantenida entre 1976 y 1978 publicada por José Carlos de Torres (2010 y 2011). José M. ${ }^{a}$ Casasayas poseyó una de las cualidades que parece ser propia de una buena parte del cervantismo, desde su consolidación como disciplina en el siglo XIX: la pasión desmedida por la obra y la figura de Cervantes, más allá de cualquier otro interés intelectual o científico. Esta pasión y entusiasmo, como ha quedado de manifiesto en las páginas precedentes, le llevó a dedicar gran parte de su vida -alejado cada vez más de sus quehaceres empresariales en su tierra mallorquina- a la creación y consolidación de la Asociación de 
Cervantistas, una tarea, en muchos casos, de naturaleza quijotesca ${ }^{27}$. Pasión, entusiasmo y personalidad que constituyó una de las señas de identidad de la $\mathrm{AC}$ desde sus orígenes hasta su muerte. Con sus luces y con sus sombras, como toda obra humana.

El reto que recayó en José Montero Reguera, como vicepresidente, y en Antonio Bernat Vistarini, como secretario de la AC en el año 2004 no fue pequeño: coger el testigo de la Asociación de Cervantistas de manos de $\mathrm{Ca}$ sasayas y mantener con vida el proyecto esculpido con los años a imagen y semejanza de su mentor. En el Congreso Internacional celebrado en Alcalá de Henares en diciembre de 2006, José Montero Reguera vio refrendado su esfuerzo y valentía con el nombramiento como Presidente, dando comienzo a una nueva etapa en la historia de la Asociación de Cervantistas, que tenía que dotarse de un nuevo estatuto para adaptarse a los cambios legales que exigía la legislación española -la Asociación de Cervantistas tiene como sede Alcalá de Henares, la «patria» de Cervantes-, al tiempo que ponía las bases para un funcionamiento de la $\mathrm{AC}$ siguiendo el modelo del resto de las asociaciones científicas, a las que muchos de los cervantistas estamos también vinculados.

Como secretario de la nueva Junta Directiva tuve el mandato del presidente José Montero de presentar una propuesta de nuevos estatutos a la Asamblea General Ordinaria que se celebraría en Münster tres años después, que fueron debatidos en primera instancia por los diferentes miembros de la Junta Directiva. Conservo como un tesoro la correspondencia electrónica intercambiada con Anthony Close, que, con su sentido común y larga experiencia al frente de la AIH y de la AISO, entre otras asociaciones, mejoró sin duda el texto final, que fue aprobado en la primera de las Asambleas Ordinarias de la AC en el CINDAC celebrada en Münster el 3 de octubre de 2009.

Además de los cambios en cuestiones legales, como la necesidad de celebrar asambleas ordinarias todos los años, los nuevos estatutos de la AC, frente a los usos anteriores, estableció un sistema más democrático para la elección de la Junta Directiva, constituida por los siguientes cargos: un Presidente, un Vicepresidente, un Secretario, un Tesorero y 6 Vocales. Todos estos cargos, a partir de este momento, serían votados de manera independiente, limitándose su duración a tres años para el Presidente, y a seis, para el resto. Esta medida, espejo de la que aparece en los estatutos de otras asociaciones científicas, nos pareció la mejor fórmula para consolidar una democratización de la $\mathrm{AC}$ que permitiera al mayor número de socios formar parte de su máximo órgano de representación y de gestión, lo que ha posibilitado en estos últimos años la renovación de investigadores al frente de la $\mathrm{AC}$ y la apertura a los más jóvenes. Sin duda, la captación de nuevos socios, muchos de ellos recién graduados o doctorados en temas cervantinos, ha sido una de

27. Así se expresa Alberto Sánchez en una carta enviada a José M. ${ }^{a}$ Casasayas y fechada en Madrid el 20 de noviembre de 1876: "Veo que Vd. ha heredado del ingenioso hidalgo manchego el tesón y la voluntad heroica al servicio desinteresado -y hasta notablemente dispendioso- de una noble causa cultural» (Torres Martínez, 2011: 250). 
las claves del éxito actual de la Asociación de Cervantistas. Una de las razones que nos permiten a todos mirar el futuro del cervantismo con ojos llenos de ilusión y esperanza.

En la actualidad (septiembre de 2014), la AC cuenta con casi 400 socios, que proceden de 34 países, lo que la convierta en la asociación más internacional después de la AIH: Alemania, Argelia, Argentina, Australia, Bélgica, Brasil, Bulgaria, Canadá, Colombia, Corea del Sur, Costa Rica, Egipto, Estados Unidos, España, Finlandia, Francia, Gran Bretaña, Grecia, Holanda, India, Irak, Irlanda, Israel, Italia, Japón, Luxemburgo, México, Perú, Polonia, Portugal, Rusia, Serbia, Suiza, Túnez y Uruguay.

Por otro lado, en este tiempo, también se han estrechado los lazos con asociaciones científicas de nuestro mismo ámbito, tal y como se ha establecido entre los fines en el artículo 4 de nuestros estatutos. En los últimos años, aprovechando la convocatoria de los Congresos Internacionales de la $\mathrm{AIH}$ y de la AISO, hemos celebrado en sus sedes nuestras Asambleas Ordinarias, y la presencia de ponencias y de comunicaciones sobre temas cervantinos se mantiene como uno de los ejes centrales en cualquiera de estas citas científicas. Por solo poner un ejemplo, el X Congreso de la Asociación Internacional Siglo de Oro celebrado en Venecia (14-18 de julio de 2014) ha contado con un total de 25 comunicaciones que se han acercado a diversos aspectos de la creación y difusión de las obras de Cervantes (véase Sáez, 2014).

En esta misma línea, desde el Congreso Internacional de la AC celebrado en Oviedo en 2012, se ha intensificado la relación con la Cervantes Society of America, con la que esperamos poder firmar algún acuerdo de colaboración en los próximos meses.

3. Como se ha indicado y como puede leerse en los artículos precedentes, los congresos y coloquios organizados por la Asociación de Cervantistas desde su primer encuentro en Alcalá de Henares en 1990 son, sin duda, su mejor memoria, su mayor tesoro. Las actas de los mismos se habían publicado en diferentes editoriales y no siempre accesibles o con ejemplares disponibles, con lo que su consulta, en muchas ocasiones, resultaba (casi) misión imposible. Por este motivo, siendo Presidente José Montero Reguera, se llegó a un acuerdo con el Centro Virtual del Instituto Cervantes para digitalizar los volúmenes publicados y la creación de un portal específico para hacer accesible y divulgar las aportaciones al cervantismo que se han ido sumando en nuestras citas científicas. Desde noviembre de 2013, ya está accesible en la red dentro de la sección de Literatura del Centro Virtual Cervantes este espacio dedicado a nuestras publicaciones ${ }^{28}$. (Imagen 1)

Miles de páginas ahora por primera vez accesibles a todos los interesados por Cervantes y su obra en cualquier parte del mundo, que se han organizado en 4 apartados, siguiendo el siguientes esquema: 


\section{-T- Centro Virtual Cervantes}

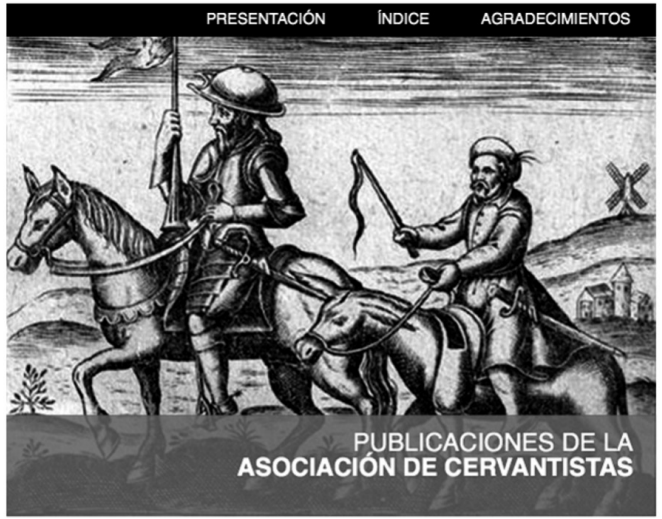

El Centro Virtual Cervantes presenta en este espacio las

PUBUCACIONES DE LA ASOCIACIÓN DE CERVANTISTAS, que en 2013 ha

celebrado los veinticinco años de sus primeros encuentros.

Tan solo faltan las actas del VIII CINDAC (Oviedo, 2012; en prensa), más las de los congresos que nunca ilegaron a publicarse: las del mimero de ellos (Almaso, 1991) las de tres de los coloquios (Alcalá de Henares, 1994, 1995 y 1996).

Durante estos veinticinco años de existencia, la Asociación de Cervantistas no ha dejado de crecer y se ha consolidado como un espacio internacional de estudio y de análisis de la vida y de la obra de Cervantes.

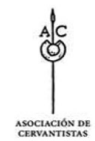

Imagen 1. Portada de las publicaciones de la AC en el Centro Virtual Cervantes

\section{Actas de congresos}

Actas del II Congreso Internacional (1995)

Actas del III Congreso Internacional (1998)

Actas del IV Congreso Internacional (2001)

Actas del V Congreso Internacional (2004)

Actas del VI Congreso Internacional (2008)

Actas del VII Congreso Internacional (2011)

\section{Actas de coloquios}

Actas del I Coloquio Internacional (1990)

Actas del II Coloquio Internacional (1991)

Actas del III Coloquio Internacional (1993)

Actas del VII Coloquio Internacional (1997)

Actas del VIII Coloquio Internacional (1999)

Actas del IX Coloquio Internacional (1999)

Actas del X Coloquio Internacional (2001)

Actas del XI Coloquio Internacional (2005)

Actas del XII Coloquio Internacional (2008) 


\section{Boletines}

Boletín I/1 (2004)

Boletín I/2 (2004)

Boletín II (2005-2007)

\section{Otras publicaciones}

Desviaciones lúdicas en la crítica cervantina (2000)

El Quijote en Buenos Aires. Lecturas cervantinas en el cuarto centenario (2006)

Cervantes y el Quijote (2007)

Cervantes and Don Quixote (2008)

Cervantes y las religiones (2008)

Ortodoxia y heterodoxia en Cervantes (2011)

4. Uno de los mandatos que asumió la nueva Junta Directiva de la AC elegida en Oviedo el 14 de junio de 2012, a la que tengo el honor de presidir, es la de crear cauces de comunicación más eficaces entre los socios de la AC, que sirvieran además para conseguir una mayor difusión de las actividades cervantinas de la AC y de sus socios. Por este motivo, en octubre del 2012 se puso en marcha El donoso escrutinio: Blog de lecturas, libros y actividades de la Asociación de Cervantistas ${ }^{29}$. (Imagen 2)

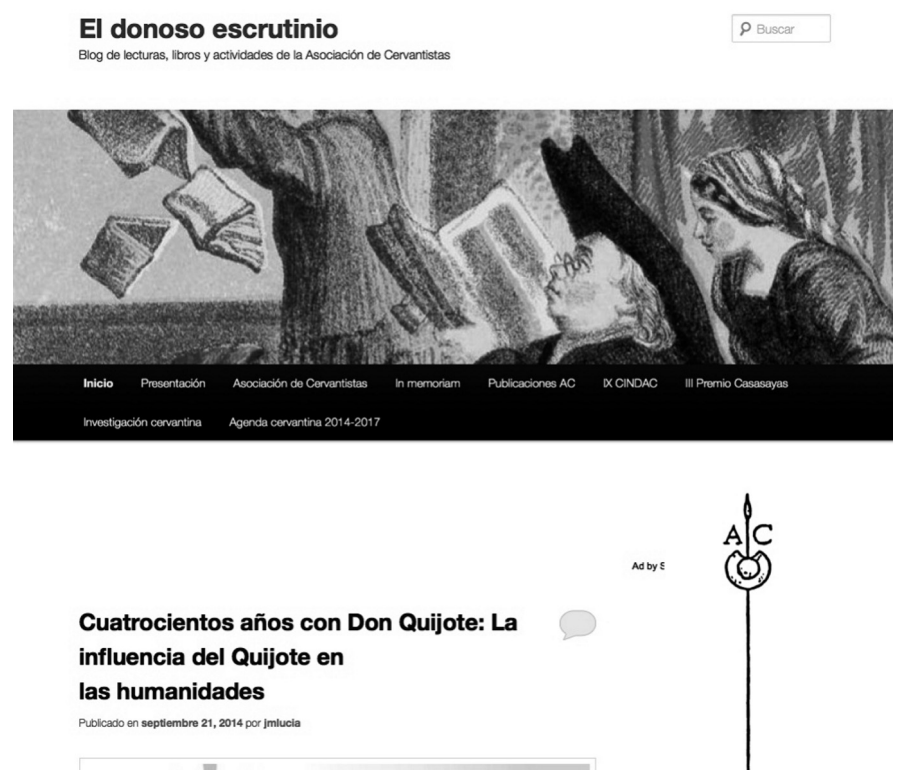

Imagen 2: Portada de «El donoso escrutinio»

29. Accesible en: <http://eldonosoescrutinio.wordpress.com/> (22/9/2014). 
El portal, que no ha dejado de crecer con el apoyo de los socios de la AC, va dando cuenta de las novedades bibliográficas cervantinas, la convocatoria de congresos, seminarios y cursos, se hace eco de las noticias que tienen a Cervantes o a su obra como protagonista, sin olvidarse de algunos temas particulares que algunos socios desean compartir con el resto del cervantismo. Un blog que permite un mejor conocimiento de la realidad cervantina en el mundo, y que esperamos que siga sumando entradas y visitas en los próximos años.

Además de las entradas de los temas mencionados, el blog ha incorporado una sección: «Investigación cervantina» ${ }^{30}$, coordinada por Adrián Sáez, en la que se quiere dar cuenta de los avances en nuestro campo, organizado en las siguientes entradas:

- Tesis en curso

- Tesis defendidas

- Libros (monografías, colectáneas)

- Proyectos editoriales en marcha

- Proyectos de investigación

- Proyectos editoriales

A estas herramientas se han unido la presencia de la Asociación de Cervantistas en dos de las redes sociales más utilizadas:

Facebook: www.facebook.com/asociacion.cervantistas

Twitter: @acervantistas

Estas herramientas informáticas con las que se ha fortalecido la $\mathrm{AC}$, que le permiten a un tiempo dar cuenta y difundir los intereses y avances del cervantismo en todo el mundo, se han visto completadas con un proyecto realizado conjuntamente con el GRISO: «Agenda cervantina 2014-2017» $»^{31}$, que se plantea recopilar información sobre las distintas actividades que se organizarán en estos años para conmemorar los diferentes centenarios cervantinos: 400 años de la publicación del Viaje del Parnaso, las Ocho comedias y entremeses, la segunda parte del Quijote y el Persiles, sin olvidar los 400 años de la muerte de Cervantes (imagen 3).

Como indican sus promotores, este proyecto nace con la pretensión de cubrir cuatro ámbitos de trabajo: fechas;

- espacio de difusión de las actividades de todo tipo programadas en estas

- herramienta para la coordinación de las mismas a lo largo del tiempo evitando los solapamientos de espacios, temas y tiempos que se vivieron en la conmemoración quijotesca del 2005;

- espacio innovador de intercambio de experiencias y de ideas, abierto a todo tipo de público, espacios y lenguas;

$-\mathrm{y}$ archivo para el futuro de las actividades realizadas. 


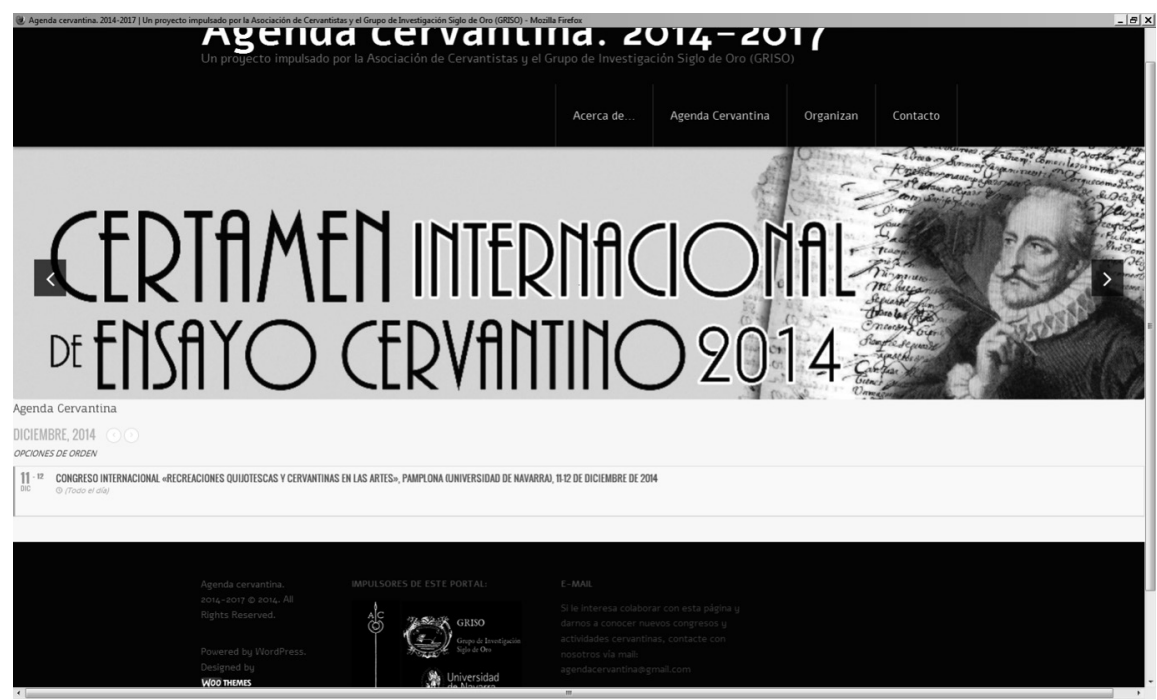

Imagen 3: Portada de la «Agenda cervantina: 2014-2017»

Estas nuevas herramientas, que en el futuro se verán ampliados por un portal web de la $\mathrm{AC}$, hacen de nuestra Asociación un espacio cervantino de diálogo, una casa de la palabra donde todo el mundo se siente acogido, donde todas las propuestas y metodologías encuentran su espacio y sus medios de difusión. Un presente esperanzador que nos obliga a plantear nuevos retos y desafíos para el futuro.

5. «En la ciudad de Alcalá de Henares, a ocho de abril de mil novecientos ochenta y ocho, y a las 12 horas, en el Salón de Sesiones del Excmo. Ayuntamiento, se reúnen los señores relacionados al margen, que constituyen la totalidad de miembros de la Asociación de Cervantistas, al objeto de efectuar su 1. Asamblea General Extraordinaria». Con estas palabras comienza el acta de la primera Asamblea de la AC. En el margen puede leerse bajo el epígrafe de «Presentes», los siguientes nombres: «Carlos Alvar / José Ares Montes / Alberto Blecua / J. M. ${ }^{a}$ Díez Taboada / Luciano García Lorenzo / F. Luttikhuizen / Jaime Moll / Alberto Sánchez / M. Sánchez Mariana / José Carlos de Torres / José M. ${ }^{a}$ Casasayas Truyols», y bajo el de «Representados» los siguientes: «Fco. Aguilar Piñal, Aurora Egido, Helena Percas / Enrique Rull». Los socios fundadores de la AC. Algunos de ellos nos han regalado sus recuerdos que encabezan las páginas de este dossier.

El punto quinto de la Asamblea se dedicó a concretar las actividades que la AC debía realizar en los siguientes años «sin orden de preferencia». Una lectura rápida de las mismas permite rescatar uno de los principios de nuestra Asociación, que debe ser también guía de nuestras perspectivas futuras: la ambición. La ambición en los fines y en los medios que hemos de poner en marcha para poder llevarlos a buen puerto. Además del apoyo y cooperación 
que se brinda a «Anales Cervantinos» como revista cervantina de cabecera, la creación de un Boletín de la Asociación, de carácter más administrativo y otro Bibliográfico, que «contenga información de todas las publicaciones cervantinas de que se tenga noticia», o la organización de Coloquios y Jornadas, sin olvidar el apoyo para la creación de una «Cátedra Cervantes» en la Universidad de Alcalá, rescato tres de los proyectos ambiciosos que se expusieran en aquella primera Asamblea General Ordinaria, que son buena prueba de su espíritu inicial:

a) «Creación de una editorial para obras cervantinas, o, por lo menos, prestar el asesoramiento pertinente al efecto a otra editorial independiente de la Asociación».

b) «Creación de una Biblioteca Cervantina que se pondrá a disposición de todos los miembros de la Asociación para sus investigaciones. A este respecto, y a causa de la carencia momentánea de los recursos económicos precisos para la adquisición de las obras, se recomienda a todos los miembros de la Asociación que procuren facilitar graciosamente a la que será Biblioteca Cervantina de la Asociación, por lo menos un ejemplar de cada una de sus obras (libros y artículos) de tema cervantino».

c) «La organización de una(s) semana(s) de Teatro Cervantino, o por lo menos de la época del Siglo de Oro, con sede principal en Alcalá de Henares».

La lectura de estas primeras metas de la Asociación de Cervantistas y la correspondencia anterior de algunos de sus protagonistas es la prueba palpable de todo lo que se ha avanzando en el cervantismo gracias a la constitución y consolidación de nuestra asociación, sin olvidar el trascendental motor que ha constituido en todos estos años el Centro de Estudios Cervantinos, dirigido por Carlos Alvar, uno de los socios fundadores de la $\mathrm{AC}$, que tiene su sede en Alcalá de Henares. Y como escribía en páginas anteriores, debemos sentirnos orgullosos del camino transitado, de las vías abiertas en estos primeros 25 años de andadura; y este orgullo y esta fuerza es la que nos debe seguir animando a pensar en nuevas empresas quijotescas o a retomar algunas de las que todavía quedan en el tintero.

La primera de las cartas del epistolario entre José M. ${ }^{a}$ Casasayas y Alberto Sánchez comienza con una carta que Casasayas envía desde Palma de Mallorca el 31 de enero de 1976, donde le da cuenta de un proyecto: un $\mathrm{Ar}$ chivo Bibliográfico Cervantino, es decir: «un catálogo de todo lo publicado referente a Cervantes». Quizás sin saberlo, Casasayas estaba recogiendo una idea que ya expusiera Juan Sedó Peris-Mencheta en un artículo publicado en la Crónica Cervantina en 1935: «Proyecto de una bibliografía general cervantina» (pp. 634-635), y que continúa siendo una de las grandes demandas del cervantismo. La magnífica Bibliografia del Quijote por unidades narrativas y materiales de la novela, publicada por Jaime Fernández S. J. en el Centro de Estudios Cervantinos en dos tomos en el año 2008, viene a suplir parte de esta demanda, así como los boletines bibliográficos que se han ido superponiendo en el tiempo, como los que tuvo nuestra Asociación desde 2004 a 2007, coordinados por José Montero Reguera y Antonio Rifón Sánchez, que hoy en 
día pueden consultarse en línea con el resto de las publicaciones de la AC en el Centro Virtual del Instituto Cervantes.

Este lugar común del cervantismo desde el siglo XIX, este deseo de contar con un espacio donde se pueda tener noticia (y ahora, acceso digital) a la bibliografía cervantina debería ser uno de los proyectos que lidere la Asociación de Cervantistas, como uno de esos servicios nuevos que las asociaciones científicas deben plantearse en el futuro. Una bibliografía cervantina que podría ser actualizada por los mismos cervantistas -socios de la $\mathrm{AC}$ - con el acceso a sus publicaciones en un portal de la $\mathrm{AC}$ en que estamos en estos momentos trabajando.

En este sentido, y para ir concluyendo estas páginas, después de haber desarrollado con éxito el proceso de reestructuración y de reorganización interna de la $\mathrm{AC}$, es el momento de poder encarar retos y desafíos, con la vista puesta en el fortalecimiento del cervantismo y la difusión de nuestras actividades, más allá del ámbito académico, donde la $\mathrm{AC}$ es ya un referente mundial.

En el primero de los campos de actuación, creo que se hace necesario consolidar los espacios de comunicación y de difusión interna que hemos abierto entre los miembros de la AC, más allá de nuestros (esperados) encuentros trianuales en los congresos internacionales: el blog de noticias y la presencia de las redes sociales, además de los boletines informativos que de manera periódica se envía desde la Junta Directiva. Uno de los modos de conseguirlo será la creación de un portal de la AC, que se presentará en nuestro próximo congreso Internacional, el que celebremos en la ciudad brasileña de Sao Paulo del 29 de junio al 3 de julio de 2015, la primera vez que la AC celebra uno de sus encuentros internacionales fuera de Europa. Está todavía por diseñar su contenido, que no puede ser mero escaparate de las actividades realizadas o proyectadas en el futuro, sino lleno de servicios para convertirle en un dinamizador del cervantismo mundial.

Por otro lado, se hace necesario un apoyo más institucional -incluso ser puente para la obtención de financiación- de los proyectos de investigación cervantinos que permita una profundización en nuestros temas de interés y una mejora en su difusión. En este sentido, sería bueno una alianza estratégica de apoyo de la Asociación de Cervantistas a los esfuerzos del Instituto Cervantes (a partir de su Centro Virtual), de la Biblioteca Virtual Miguel de Cervantes y de la Biblioteca Nacional de España, que está catalogando su rico fondo cervantino - sin duda, el mejor de todo el mundo-, para así poder ofrecerlo a la comunidad científica durante las celebraciones cervantinas de los próximos años.

Además de los esfuerzos por mejorar la comunicación interna entre los cervantistas de todo el mundo, así como de las personas interesadas en la obra y la vida de Cervantes, de fortalecer nuestros cauces de difusión (con Anales Cervantinos a la cabeza), con el apoyo de las plataformas digitales que dan cabida a portales cervantinos y quijotescos, y de los proyectos o grupos de investigación que se dedican a estudiar y analizar la vida y la obra de Cer- 
vantes, creo que la AC está en disposición de dar un salto para ser conocida y reconocida por la sociedad como un referente en todo lo que tenga que ver con asuntos cervantinos. Lamentablemente, la aparición de francotiradores -que saben que poniendo el nombre de Cervantes o del Quijote en un título, en una institución, en una colección o editorial, tienen parte de su éxito asegurado- es inevitable, y más cuando se avecinan años de celebraciones, como serán los años 2015 y 2016. Lo triste es que las instituciones públicas no hayan sido capaces de atajar este problema de raíz, y se dejan arrastrar por unos proyectos mediáticos que -como sucedió con la mayoría de las actividades programadas en el año 2005- no aportan nada al cervantismo, y solo sirven para aumentar patrimonios particulares. Mientras escribo estas páginas que se publicarán en una revista de prestigio como Anales Cervantinos, recuerdo dos noticias, más o menos recientes, que no dejan mucho espacio para el optimismo en este campo: en el mes de julio se anunció a bombo y platillo que Alcalá de Henares estaba dispuesta a celebrar como se merecía las conmemoraciones del 2015 (400 años de la publicación de los Entremeses y Comedias de Cervantes, así como de la segunda parte del Quijote) y del 2016 (la muerte de Cervantes y el final de la escritura del Persiles), y para ello contaba con la coordinación de la Fundación Cervantes 2016. En la ciudad de Alcalá de Henares, patria de Cervantes, sede de la Asociación de Cervantistas hace 25 años y casi el mismo tiempo del Centro de Estudios Cervantinos, ahora convertido en Instituto de investigación dependiente de la Universidad de Alcalá, se deja en manos de una empresa recién creada, cuyo mentor es Luis M. ${ }^{a}$ Ansón, tan importante celebración. ¿A alguien le extraña ahora por qué Alcalá de Henares no fuera declarada Capital Europea de la Cultura en el 2016? Y una última pincelada, que el tiempo borrará, pero que se ha producido justo en el momento de redacción de estas líneas. El grupo parlamentario de Izquierda Plural (IU, ICV-EUiA, CHA) presentó una proposición no de ley a la Comisión de Cultura del Congreso de los Diputados el 23 de septiembre de 2014 con el siguiente título: «Relativa a la celebración del VII Congreso de la lengua española en Alcalá de Henares y el Cuarto Centenario de la muerte de Miguel de Cervantes». Proposición en que se instaba al gobierno a «La creación de una comisión organizadora cuyo fin sea la elaboración de un programa de actuaciones y actividades para la celebración del $4 .^{\circ}$ centenario de la muerte de Miguel de Cervantes, implicando en la misma a la Consejería de Empleo, Turismo y Cultura de la Comunidad de Madrid y a la Sociedad Estatal de Conmemoraciones Culturales, dependiente del Ministerio de Educación, Cultura y Deporte». La diputada Ascensión de la Heras, de Izquierda Plural, según recoge la Agencia EFE, se permite además avanzar cuáles deben ser los ejes sobre los que giren las celebraciones: su faceta de dramaturgo y el Persiles: Ascensión de las Heras, de Izquierda Plural, ha puesto de relieve el carácter «helenístico» de la última obra que escribió Cervantes, y ha hecho hincapié en que la ciudad natal del escritor, Alcalá de Henares (Madrid), cobre protagonismo en la celebración». Sin comentarios. 
Este es, sin duda, uno de los grandes desafíos de la AC, uno de los molinos de viento a los que tendrá que hacer frente -esperemos que con mejor fortuna que la que tuvo don Quijote-: la de conseguir hacer ver a la sociedad -y a los dirigentes que gestionan la res publica - la necesidad de contar con los cervantistas, con los que dedicamos nuestra vida, nuestro conocimiento, nuestro entusiasmo al conocimiento y estudio de Cervantes y de su obra, a la hora de asesorar y planificar un programa de conmemoraciones que suponga un avance en la sociedad, y no solamente un impacto económico en determinadas ciudades, instituciones y personas. Habrá que estar muy atento a las celebraciones cervantinas de los próximos años y hacer escuchar nuestra voz de cervantistas, la única realmente autorizada, para alabar y destacar las actividades que aporten un avance en el conocimiento o en la difusión de Cervantes y de su obra (y de la cultura en general), pero también para denunciar el derroche de dinero público, el escaso interés de muchos de los proyectos felizmente financiados y la falta de previsión y de gestión de las administraciones públicas, cuando así suceda. Ante las tropelías que se hagan en nombre de Cervantes, la Asociación de Cervantistas, los cervantistas de todo el mundo no podemos quedarnos en silencio.

Nos esperan años de grandes desafíos, de retos quijotescos, y qué mejor espacio que la Asociación de Cervantistas para encararlos y vencerlos.

\section{APÉNDICE}

Juntas directivas de la Asociación de Cervantistas

(1988-2015)

1988-1989

(ELECCIONES DE 8 DE ABRIL DE 1988)

Presidente: D. Alberto Sánchez.

Vicepresidente: D. José María Casasayas Truyols.

Secretario: D. José Carlos de Torres Martínez.

Tesorero: D. Juan María Díez Taboada.

Bibliotecario: D. Carlos Alvar.

1989-1991

(ELECCIONES DEL 9 DE NOVIEMBRE DE 1989)

Presidente: D. Alberto Sánchez.

Vicepresidente y tesoreso: D. José María Casasayas Truyols.

Secretario: D. José Carlos de Torres Martínez.

Vocales: D. a Aurora Egido, D. Luciano García Lorenzo y D. Juan María Díez Taboada. 
1991-1995

(ELECCIONES DEL 27 DE NOVIEMBRE DE 1991)

Presidente: D. Alberto Sánchez.

Vicepresidente: D. José María Casasayas Truyols.

Secretario: D. José Carlos de Torres Martínez.

Vocales: D. ${ }^{a}$ Aurora Egido, D. Luciano García Lorenzo y D. Juan María Díez Taboada, Javier Herrero, Carlos Alvar y Santiago Alfonso López Navia.

$$
1995-1999
$$

(ELECCIONES DEL 15 DE MARZO DE 1995)

Presidente: D. Alberto Blecua Perdices

Vicepresidente: D. José Carlos de Torres Martínez.

Secretario y tesorero: D. Santiago Alfonso López Navia.

Vocales: D. ${ }^{a}$ Aurora Egido, D. Juan Bautista de Avalle-Arce, D. Jean Canavaggio, D. Daniel Eisenberg, D. Francisco Márquez Villanueva, D. Michel Moner, y D. Carlos Romero Muñoz.

$$
1999-2004
$$

(ELECCIONES DEL 26 DE NOVIEMBRE DE 1999)

Presidente: D. José María Casasayas Truyols.

Vicepresidente: D. José Carlos de Torres Martínez.

Secretario: D. Antonio Bernat Vistarini.

Vocales: D. ${ }^{a}$ Aurora Egido, D. Carlos Alvar, D. Daniel Eisenberg, D. Augustin Redondo, D. Eduardo Urbina, y D. Santiago López Navia.

$$
\begin{aligned}
& 2004 \text { - } 2006 \\
& \text { (ELECCIONES DEL } 16 \text { DE FEBRERO DE 2004) }
\end{aligned}
$$

Presidente: D. José María Casasayas Truyols.

Vicepresidente: D. José Montero Reguera.

Secretario: D. Antonio Bernat Vistarini.

Vocales: D. ${ }^{a}$ Aurora Egido Martínez, D. Carlos Alvar, D. Daniel Eisenberg, D. Augustin Redondo, D. Eduardo Urbina, y D. Santiago López Navia, D. Anthony Close. D. Jacques Joset, D. ${ }^{a}$ Isabel Lozano Renieblas, D. ${ }^{a}$ Alicia Villar Lecumberri y D. José Carlos de Torres Martínez.

$$
\text { 2006-2009 }
$$

(ElecCiONES DEL 15 DE DiCIEMBRE DE 2006)

Presidente: D. José Montero Reguera (Universidad de Vigo)

Vicepresidenta: D. ${ }^{\mathrm{a}}$ Isabel Lozano Renieblas (Dartmouth College)

Tesorera: D. ${ }^{a}$ Alicia Villar Lecumberri (Universidad Autónoma de Madrid)

Secretario: D. José Manuel Lucía Megías (Universidad Complutense de Madrid). 
Vocales: D. a María Fernanda Abreu (Universidad Nova de Lisboa),

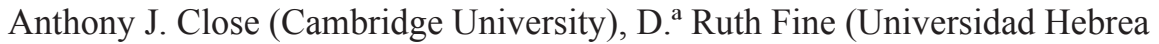
de Jerusalén), Santiago López Navia (Universidad SEK, Segovia), José Manuel Martín Morán (Universidad del Piamonte Oriental), Emilio Martínez Mata (Universidad de Oviedo), Michel Moner (Universidad de Toulouse Le Mirail), Carlos Romero Muñoz (Universidad de Venecia) y D. ${ }^{a}$ Caterina Ruta (Universidad de Palermo).

2009-2012

(EleCCIONES EL 3 DE OCTUBRE DE 2009)

Presidente: D. José Montero Reguera (Universidad de Vigo)

Vicepresidenta: D. ${ }^{\text {a }}$ Caterina Ruta (Universidad de Palermo)

Tesorera: D. ${ }^{a}$ Alicia Villar Lecumberri (Universidad Autónoma de Madrid)

Secretario: D. José Manuel Lucía Megías (Universidad Complutense de Madrid)

Vocales: D. ${ }^{a}$ María Fernanda Abreu (Universidad Nova de Lisboa), D. ${ }^{a}$ Ruth Fine (Universidad Hebrea de Jerusalén), Aurelio González (Colegio de México), Robert Lauer (The University of Oklahoma), José Manuel Martín Morán (Universidad del Piamonte Oriental), Emilio Martínez Mata (Universidad de Oviedo), Michel Moner (Universidad de Toulouse Le Mirail), Christoph Strosetzki (Universidad de Münster) y Maria Augusta da Costa Vieira (Universidade de Sao Paulo)

\section{2-2015}

(ELECCIONES 14 DE JUNIO DE 2012)

Presidente: D. José Manuel Lucía Megías (Universidad Complutense de Madrid, España)

Vicepresidenta: D. ${ }^{\text {a }}$ Caterina Ruta (Universidad de Palermo, Italia)

Secretaria: D. a Alicia Villar Lecumberri (Universidad Autónoma de Madrid, España)

Tesorera: D. ${ }^{a}$ Alexia Dotras Bravo (Universidade de Bragança, Portugal)

Vocales: Aurelio González (Colegio de México-UNAM, México), Steven Hutchinson (University of Wisconsin-Madison, USA), Kenji Inamoto (Universidad Doshisha, Japón), Robert Lauer (The University of Oklahoma, USA), Vibha Maurya (Universidad de Delhi, India), Jasna Stojanovic, Universidad de Belgrado, Serbia), Christoph Strosetzki (Universidad de Münster), Bénédicte Torres (Université de Lille 3, Francia) y Maria Augusta da Costa Vieira (Universidade de Sao Paulo, Brasil)

\section{BIBLIOGRAFÍA}

Abi-Ayad, Ahmed (1995). «Argel: Una etapa decisiva en la obra y pensamiento de Cervantes», en G. Grilli (ed.), Actas del II Congreso Internacional de la Asociación de Cervantistas (II CINDAC). Nápoles: Società Intercontinentale Gallo, pp. 133-42. 
Abreu, María Fernanda (2004). «Cervantes en Portugal», en Alicia Villar Lecumberri (ed.), Peregrinamente peregrinos. Actas del V Congreso Internacional de la Asociación de Cervantistas (V CINDAC). Palma de Mallorca: Asociación de Cervantistas, I, pp. 3-15.

Asociación de Cervantistas (1990). Actas del I Coloquio Internacional de la Asociación de Cervantistas (I CIAC). Barcelona: Anthropos.

Asociación de Cervantistas (1991). Actas del II Coloquio Internacional de la Asociación de Cervantistas. (II CIAC). Barcelona: Anthropos.

Aladro, Jordi (2014). «La Numancia, Cervantes y Felipe II», en Emilio Martínez Mata y María Fernández Ferreiro (ed.), Comentarios a Cervantes. Actas selectas del VIII Congreso Internacional de la Asociación de Cervantistas (VIII CINDAC). Madrid: Fundación María Cristina Masaveu Peterson, pp. 932-945.

Alcalá Galán, Mercedes (2014). «Personajes espejo en el ámbito del Islam: la inverosimilitud como crítica ideológica», en Emilio Martínez Mata y María Fernández Ferreiro (ed.), Comentarios a Cervantes. Actas selectas del VIII Congreso Internacional de la Asociación de Cervantistas (VIII CINDAC). Madrid: Fundación María Cristina Masaveu Peterson, pp. 946-957.

Alcalá Galán, Mercedes (2004). «El Persiles en secuencia: coherencia y radicalidad artística de la obra final de Cervantes: "Aquí soy yo señor de mí mismo"», en Alicia Villar Lecumberri (ed.), Peregrinamente peregrinos. Actas del V Congreso Internacional de la Asociación de Cervantistas (V CINDAC). Palma de Mallorca: Asociación de Cervantistas, I, pp. 151-163.

Alcalá Galán, Mercedes (2001). «Ese "divino don del habla": hacia una poética de la narración en el Coloquio de los perros y El casamiento engañoso», en Antonio Bernat Vistarini (ed.), Volver a Cervantes. Actas del IV Congreso Internacional de la Asociación de Cervantistas (IV CINDAC). Palma de Mallorca: Universitat de les Illes Balears, II, pp. 773-777.

Alcalá Galán, Mercedes (1998). «Épica y novela en el Quijote», en Antonio Bernat Vistarini (ed.), Actas del Tercer Congreso Internacional de la Asociación de Cervantistas (III CINDAC). Palma: Universitat de les Illes Balears, pp. 315-323.

Alcalá-Galán, Mercedes, Steven Hutchinson, Francisco Layna Ranz y Adrienne L. Martín (2014). «El cervantismo en Estados Unidos», en Emilio Martínez Mata y María Fernández Ferreiro (ed.), Comentarios a Cervantes. Actas selectas del VIII Congreso Internacional de la Asociación de Cervantistas (VIII CINDAC). Madrid: Fundación María Cristina Masaveu Peterson, pp. 139-152.

Álvarez Amell, Diana (1995). «El arte y la naturaleza: el espacio de la creación en el prólogo de Don Quijote», en G. Grilli (ed.), Actas del II Congreso Internacional de la Asociación de Cervantistas (II CINDAC). Nápoles: Società Intercontinentale Gallo, pp. 269-274.

Andrés, Christian (1998). «Figuras alegóricas y teatralidad en la obra dramática de Cervantes», en Antonio Bernat Vistarini (ed.), Actas del Tercer Congreso Internacional de la Asociación de Cervantistas (III CINDAC). Palma: Universitat de les Illes Balears, pp. 545-557.

Armstrong-Roche, Michael (2004). «Europa como bárbaro Nuevo Mundo en la novela épica de Cervantes», en Alicia Villar Lecumberri (ed.), Peregrinamente peregrinos. Actas del V Congreso Internacional de la Asociación de Cervantistas (V CINDAC). Palma de Mallorca: Asociación de Cervantistas, II, pp. 1123-1138.

Antiochos, Sarantis (2001). «Cervantes y El Greco: ¿solo contemporáneos?», en Antonio Bernat Vistarini (ed.), Volver a Cervantes. Actas del IV congreso internacional de la Asociación de Cervantistas. Palma de Mallorca: Universitat de les Illes Balears, I, pp. 91-103. 
Arena, Silvana Mariel (1998). «Triguillos, el zahorí, frente al tesoro de Preciosa. Avances para el estudio de la construcción de una identidad ejemplar en Cervantes», en Antonio Bernat Vistarini (ed.), Actas del Tercer Congreso Internacional de la Asociación de Cervantistas (III CINDAC). Palma: Universitat de les Illes Balears, pp. 430-444.

Bailón Blancas, José Manuel (1995). «Un modelo de depresión neurótica en la obra de Cervantes: El curioso impertinente», en G. Grilli (ed.), Actas del II Congreso Internacional de la Asociación de Cervantistas (II CINDAC). Nápoles: Società Intercontinentale Gallo, pp. 463-486.

Baquero Escudero, Ana L. (2004), «La estructura narrativa en el episodio del rey Policarpo», en Alicia Villar Lecumberri (ed.), Peregrinamente peregrinos. Actas del V Congreso Internacional de la Asociación de Cervantistas (V CINDAC). Palma de Mallorca: Asociación de Cervantistas, I, pp. 207-220.

Barrado de Álvaro, Margarita (2011). «Rinconete y Cortadillo en Alemania. Una visión del Imperio», en Christoph Strosetzki (ed.), Visiones y revisiones cervantinas. Actas selectas del VII Congreso Internacional de la Asociación de Cervantistas (VII CIN$D A C)$. Alcalá de Henares: Centro de Estudios Cervantinos, pp. 163-169.

Bernat Vistarini, Antonio (2001a). «"Componer libros para dar a la estampa” y las maravillas de la Cueva de Montesinos», en Antonio Bernat Vistarini (ed.), Volver a Cervantes. Actas del IV Congreso Internacional de la Asociación de Cervantistas (IV CIN$D A C$ ). Palma de Mallorca: Universitat de les Illes Balears, I, pp. 671-684.

Bernat Vistarini, Antonio (2001b) (ed.). Volver a Cervantes. Actas del IV Congreso Internacional de la Asociación de Cervantistas (IV CINDAC). Palma de Mallorca: Universitat de les Illes Balears.

Antonio Bernat Vistarini (ed.) (1998). Actas del Tercer Congreso Internacional de la Asociación de Cervantistas (III CINDAC). Palma: Universitat de les Illes Balears.

Bernat Vistarini, Antonio (1995). «Algunos motivos emblemáticos en la poesía de Cervantes», en G. Grilli (ed.), Actas del II Congreso Internacional de la Asociación de Cervantistas (II CINDAC). Nápoles: Società Intercontinentale Gallo, pp. 83-95.

Borham Puyal, Miriam (2014). «Otra vuelta de tuerca al cervantismo: técnicas cervantinas en la obra de Tabitha Tenney y Mary Brunton», en Emilio Martínez Mata y María Fernández Ferreiro (ed.), Comentarios a Cervantes. Actas selectas del VIII Congreso Internacional de la Asociación de Cervantistas (VIII CINDAC). Madrid: Fundación María Cristina Masaveu Peterson, pp. 592-603.

Blanco, Mercedes (1995). «Literatura e ironía en Los trabajos de Persiles y Sigismunda», en G. Grilli (ed.), Actas del II Congreso Internacional de la Asociación de Cervantistas (II CINDAC). Nápoles: Società Intercontinentale Gallo, pp. 625-635.

Blanco-Camblor, María Luz (2004). «Cervantes y Sor Juana Inés de la Cruz. Consideraciones sobre la situación de la mujer en el Siglo de Oro a la luz de las Novelas Ejemplares y Ocho Comedias y ocho entremeses nuevos, nunca representados», en Alicia Villar Lecumberri (ed.), Peregrinamente peregrinos. Actas del V Congreso Internacional de la Asociación de Cervantistas (V CINDAC). Palma de Mallorca: Asociación de Cervantistas, II, pp. 1177-1200.

Blanco Mallada, Lucio (2008). «La Mancha en el documental cinematográfico español», en Alexia Dotras Bravo, José Manuel Lucía Megías, Elisabet Magro García y José Montero Reguera (ed.), Tus obras los rincones de la tierra descubren. Actas del VI Congreso Internacional de la Asociación de Cervantistas (VI CINDAC). Alcalá de Henares: Centro de Estudios Cervantinos, pp. 155-165.

Boruchoff, David A. (2004). «El fin de los amores de Teágenes y Cariclea, y los fines del Persiles», en Alicia Villar Lecumberri (ed.), Peregrinamente peregrinos. Actas del V 
Congreso Internacional de la Asociación de Cervantistas (V CINDAC). Palma de Mallorca: Asociación de Cervantistas, I, pp. 221-237.

Boruchoff, David A. (2001). «Persiles y la poética de la salvación cristiana», en Antonio Bernat Vistarini (ed.), Volver a Cervantes. Actas del IV Congreso Internacional de la Asociación de Cervantistas (IV CINDAC). Palma de Mallorca: Universitat de les Illes Balears, II, pp. 853-874.

Boscán de Lombardi, Lilia (2001). «Visiones y encantamientos en la Cueva de Montesinos», en Antonio Bernat Vistarini (ed.), Volver a Cervantes. Actas del IV Congreso Internacional de la Asociación de Cervantistas (IV CINDAC). Palma de Mallorca: Universitat de les Illes Balears, I, pp. 685-689.

Botta, Patrizia (2008). «Escollos de traducción en el Quijote (I)», en Alexia Dotras Bravo, José Manuel Lucía Megías, Elisabet Magro García y José Montero Reguera (ed.), Tus obras los rincones de la tierra descubren. Actas del VI Congreso Internacional de la Asociación de Cervantistas (VI CINDAC). Alcalá de Henares: Centro de Estudios Cervantinos, pp. 167-180.

Brito Díaz, Carlos (1998). «"De que todo sea comedia, / y no tragedia, me alegro": la escrilectura teatral de Cervantes en La entretenida», en Antonio Bernat Vistarini (ed.), Actas del Tercer Congreso Internacional de la Asociación de Cervantistas (III CIN$D A C)$. Palma: Universitat de les Illes Balears, pp. 559-569.

Campos y Fernández de Sevilla, F. Javier (2001). «Cervantes, Lepanto y El Escorial (Nueva interpretación de la historiografía clásica sobrela relación existente entre la batalla naval y el monasterio, a la luz de los documentos de la época y del propio testimonio de Cervantes)», en Antonio Bernat Vistarini (ed.), Volver a Cervantes. Actas del IV Congreso Internacional de la Asociación de Cervantistas (IV CINDAC). Palma de Mallorca: Universitat de les Illes Balears, I, pp. 3-24.

Canavaggio, Jean (1998). «El senequismo de la Numancia: Hacia un replanteamiento», en Antonio Vernat Vistarini (ed.), Actas del Tercer Congreso Internacional de la Asociación de Cervantistas (III CINDAC). Palma: Universitat de les Illes Balears, pp. 3-11.

Cascardi, Anthony J. (2001). «Dos formas del saber en Cervantes, Platón y Aristóteles», en Antonio Bernat Vistarini (ed.), Volver a Cervantes. Actas del IV Congreso Internacional de la Asociación de Cervantistas (IV CINDAC). Palma de Mallorca: Universitat de les Illes Balears, I, pp. 303-309.

Cash, Annette G. (2008). «Formas de tratamiento en Don Quijote», en Alexia Dotras Bravo, José Manuel Lucía Megías, Elisabet Magro García y José Montero Reguera (ed.), Tus obras los rincones de la tierra descubren. Actas del VI Congreso Internacional de la Asociación de Cervantistas (VI CINDAC). Alcalá de Henares: Centro de Estudios Cervantinos, pp. 225-232.

Castillo Gómez, Antonio (2001). «La escritura representada. Imágenes de lo escrito en la obra de Cervantes», en Antonio Bernat Vistarini (ed.), Volver a Cervantes. Actas del IV Congreso Internacional de la Asociación de Cervantistas (IV CINDAC). Palma de Mallorca: Universitat de les Illes Balears, I, pp. 311-325.

Carrasco Urgoiti, M ${ }^{\text {a }}$ Soledad (1998). «El gallardo español como héroe fronterizo», en Antonio Bernat Vistarini (ed.), Actas del Tercer Congreso Internacional de la Asociación de Cervantistas (III CINDAC). Palma: Universitat de les Illes Balears, pp. 571581.

Cervantes Saavedra, Miguel de (2004 [2005]). L'enginyós cavaller Don Quixot de la Manxa, Joseph M. ${ }^{a}$ Casasayas Truyols (trad. y ed.). Ciutat de Mallorca: A costa del Traductor.

Chaparro Domínguez, María Ángeles (2014). «El tratamiento mediático del III y el IV Centenario de la publicación de la Primera Parte del Quijote: análisis de las principa- 
les cabeceras españolas de 1905 y 2005», en Emilio Martínez Mata y María Fernández Ferreiro (ed.), Comentarios a Cervantes. Actas selectas del VIII Congreso Internacional de la Asociación de Cervantistas (VIII CINDAC). Madrid: Fundación María Cristina Masaveu Peterson, pp. 604-615.

Chen Sham, Jorge (2004). «Modalidades del sueño ficcional en el Persiles», en Alicia Villar Lecumberri (ed.), Peregrinamente peregrinos. Actas del V Congreso Internacional de la Asociación de Cervantistas (V CINDAC). Palma de Mallorca: Asociación de Cervantistas, I, pp. 269-280.

Cirillo, Teresa (1995). «Nápoles en el Viaje del Parnaso cervantino y en dos parnasos partenopeos», en G. Grilli (ed.), Actas del II Congreso Internacional de la Asociación de Cervantistas (II CINDAC). Nápoles: Società Intercontinentale Gallo, pp. 65-73.

Close, Anthony J. (2011). «La metalepsis cervantina. Breve historia de un malentendido», en Christoph Strosetzki (ed.), Visiones y revisiones cervantinas. Actas selectas del VII Congreso Internacional de la Asociación de Cervantistas (VII CINDAC). Alcalá de Henares: Centro de Estudios Cervantinos, pp. 77-105.

Close, Anthony J. (2008). «La aportación de tres hispanistas franceses al estudio del folklore en el Quijote», en Alexia Dotras Bravo, José Manuel Lucía Megías, Elisabet Magro García y José Montero Reguera (ed.), Tus obras los rincones de la tierra descubren. Actas del VI Congreso Internacional de la Asociación de Cervantistas (VI CINDAC). Alcalá de Henares: Centro de Estudios Cervantinos, pp. 233-246.

Colahan, Clark (2014). «El temario e imaginario del Persiles a través de la lente de Petrarca y Hernando de Hozes», en Emilio Martínez Mata y María Fernández Ferreiro (ed.), Comentarios a Cervantes. Actas selectas del VIII Congreso Internacional de la Asociación de Cervantistas (VIII CINDAC). Madrid: Fundación María Cristina Masaveu Peterson, pp. 1028-1038.

Colahan, Clark (2004). «Sulpicia y la Sensualidad: un caso de pentimento petrarquista en Persiles y Sigismunda», en Alicia Villar Lecumberri (ed.), Peregrinamente peregrinos. Actas del V Congreso Internacional de la Asociación de Cervantistas (V CINDAC). Palma de Mallorca: Asociación de Cervantistas, I, pp. 281-290.

Collins, Marsha S. (2001). «Entre el apetito y la razón: el poder de la confesión en Las dos doncellas», en Antonio Bernat Vistarini (ed.), Volver a Cervantes. Actas del IV Congreso Internacional de la Asociación de Cervantistas (IV CINDAC). Palma de Mallorca: Universitat de les Illes Balears, II, pp. 779-783.

Costa Vieira, María Augusta da (2014). «Conversaciones de don Quijote», en Emilio Martínez Mata y María Fernández Ferreiro (ed.), Comentarios a Cervantes. Actas selectas del VIII Congreso Internacional de la Asociación de Cervantistas (VIII CIN$D A C)$. Madrid: Fundación María Cristina Masaveu Peterson, pp. 565-572.

Costa Vieira, María Augusta da (1995). «Autorreferencialidad textual y construcción del personaje don Quijote», en G. Grilli (ed.), Actas del II Congreso Internacional de la Asociación de Cervantistas (II CINDAC). Nápoles: Società Intercontinentale Gallo, pp. 363-370.

Cruz Casado, Antonio (2008). «Revisión de una hipótesis: Juan Valladares de Valdelomar, autor del Quijote apócrifo», en Alexia Dotras Bravo, José Manuel Lucía Megías, Elisabet Magro García y José Montero Reguera (ed.), Tus obras los rincones de la tierra descubren. Actas del VI Congreso Internacional de la Asociación de Cervantistas (VI CINDAC). Alcalá de Henares: Centro de Estudios Cervantinos, pp. 269-283.

Cruz Casado, Antonio (2004). «Una interpretación ocultista de Los trabajos de Persiles y Sigismunda», en Alicia Villar Lecumberri (ed.), Peregrinamente peregrinos. Actas del $V$ Congreso Internacional de la Asociación de Cervantistas (V CINDAC). Palma de Mallorca: Asociación de Cervantistas, I, pp. 315-330. 
Díaz de Alda Heikkilä, M ${ }^{\text {a }}$ Carmen (2001). «Ultima Thule» y el contexto nórdico de Los trabajos de Persiles y Sigismunda», en Antonio Bernat Vistarini (ed.), Volver a Cervantes. Actas del IV Congreso Internacional de la Asociación de Cervantistas (IV CINDAC). Palma de Mallorca: Universitat de les Illes Balears, II, pp. 875-885.

Díaz Migoyo, Gonzalo (2001). «Antes de leer el Quijote: impertinencia prologal y deformación lectora», en Antonio Bernat Vistarini (ed.), Volver a Cervantes. Actas del IV Congreso Internacional de la Asociación de Cervantistas (IV CINDAC). Palma de Mallorca: Universitat de les Illes Balears, I, pp. 539-543.

Dotras Bravo, Alexia (2008). «Para la génesis de Guía del lector del "Quijote" de Madariaga», en Alexia Dotras Bravo, José Manuel Lucía Megías, Elisabet Magro García y José Montero Reguera (ed.), Tus obras los rincones de la tierra descubren. Actas del VI Congreso Internacional de la Asociación de Cervantistas (VI CINDAC). Alcalá de Henares: Centro de Estudios Cervantinos, pp. 285-295.

Dotras Bravo, Alexia, (2014). «El impacto en los estudios feministas cervantinos del IV Centenario del Quijote», en Emilio Martínez Mata y María Fernández Ferreiro (ed.), Comentarios a Cervantes. Actas selectas del VIII Congreso Internacional de la Asociación de Cervantistas (VIII CINDAC). Madrid: Fundación María Cristina Masaveu Peterson, pp. 616-625.

Duce García, Jesús (2001). «Apuntes de realismo y originalidad en Don Olivante de Laura», en Antonio Bernat Vistarini (ed.), Volver a Cervantes. Actas del IV Congreso Internacional de la Asociación de Cervantistas (IV CINDAC). Palma: Universitat de les Illes Balears, pp. 517-530.

Egido, Aurora (2011). «El gusto de don Quijote y el placer del autor y de los lectores», en Christoph Strosetzki (ed.), Visiones y revisiones cervantinas. Actas selectas del VII Congreso Internacional de la Asociación de Cervantistas (VII CINDAC). Alcalá de Henares: Centro de Estudios Cervantinos, pp. 51-76.

Egido, Aurora (2004). «Los trabajos en el Persiles», en Alicia Villar Lecumberri (ed.), Peregrinamente peregrinos. Actas del V Congreso Internacional de la Asociación de Cervantistas (V CINDAC). Palma de Mallorca: Asociación de Cervantistas, I, pp. 1766.

Egido, Aurora (1998). «Poesía y peregrinación en el Persiles: el templo de la Virgen de Guadalupe», en Antonio Bernat Vistarini (ed.), Actas del Tercer Congreso Internacional de la Asociación de Cervantistas (III CINDAC). Palma: Universitat de les Illes Balears, pp. 13-41.

Eisenberg, Daniel (2004). «Recuerdos de Pepe [José María Casasayas]», Cervantes. 24.2, pp. 193-199.

Eisenberg, Daniel (2001). «Estado actual del estudio de los libros de caballerías castellanos», en Antonio Bernat Vistarini (ed.), Volver a Cervantes. Actas del IV Congreso Internacional de la Asociación de Cervantistas (IV CINDAC). Palma de Mallorca: Universitat de les Illes Balears, I, pp. 531-536.

Endress, Heinz-Peter (2014). «El fenómeno de lo colectivo en La Numancia de Cervantes», en Emilio Martínez Mata y María Fernández Ferreiro (ed.), Comentarios a Cervantes. Actas selectas del VIII Congreso Internacional de la Asociación de Cervantistas (VIII CINDAC). Madrid: Fundación María Cristina Masaveu Peterson, pp. 958-962.

Endress, Heinz-Peter (1998). «Sobre las razones de la presencia de discursos y de retórica en el Quijote», en Antonio Bernat Vistarini (ed.), Actas del Tercer Congreso Internacional de la Asociación de Cervantistas (III CINDAC). Palma: Universitat de les Illes Balears, pp. 325-334.

Fernández García, Laura (2001). «Las erratas del Persiles: nuevas, falsas y enmendadas», en Antonio Bernat Vistarini (ed.), Volver a Cervantes. Actas del IV Congreso Interna- 
cional de la Asociación de Cervantistas (IV CINDAC). Palma de Mallorca: Universitat de les Illes Balears, II, pp. 887-894.

Filippís, Dimitris, E. (2001). «Mijaíl Chervantes-Servantis-Kervantis-Ker-vantes-Cervantés-Cervantes (datos sobre la difusión de la obra cervantina en Grecia)», en Antonio Bernat Vistarini (ed.), Volver a Cervantes. Actas del IV Congreso Internacional de la Asociación de Cervantistas (IV CINDAC). Palma de Mallorca: Universitat de les Illes Balears, I, pp. 67-74.

Fine, Ruth (2008). «Alcances y función del referente en bíblico en La Galatea», en Alexia Dotras Bravo, José Manuel Lucía Megías, Elisabet Magro García y José Montero Reguera (ed.), Tus obras los rincones de la tierra descubren. Actas del VI Congreso Internacional de la Asociación de Cervantistas (VI CINDAC). Alcalá de Henares: Centro de Estudios Cervantinos, pp. 307-318.

Fine, Ruth (2004). «El libro de Ester: un posible referente de La gran Sultana»», en Alicia Villar Lecumberri (ed.), Peregrinamente peregrinos. Actas del V Congreso Internacional de la Asociación de Cervantistas (V CINDAC). Palma de Mallorca: Asociación de Cervantistas, II, pp. 1310-1329.

Fine, Ruth (2001). «La presencia del Antiguo Testamento en el Quijote», en Antonio Bernat Vistarini (ed.), Volver a Cervantes. Actas del IV Congreso Internacional de la Asociación de Cervantistas (IV CINDAC). Palma de Mallorca: Universitat de les Illes Balears, I, pp. 479-490.

Finello, Dominick (1995). «Técnica retórica y dramática de las narraciones breves de la primera parte del Quijote», en G. Grilli (ed.), Actas del II Congreso Internacional de la Asociación de Cervantistas (II CINDAC). Nápoles: Società Intercontinentale Gallo, pp. 447-453.

Gagliardi, Antonio (2004). «Humanismo laico y humanismo cristiano en el Persiles», en Alicia Villar Lecumberri (ed.), Peregrinamente peregrinos. Actas del V Congreso Internacional de la Asociación de Cervantistas (V CINDAC). Palma de Mallorca: Asociación de Cervantistas, I, pp. 399-411.

Gallota, Aldo (1995). «Cervantes y Turquía», en G. Grilli (ed.), Actas del II Congreso Internacional de la Asociación de Cervantistas (II CINDAC). Nápoles: Società Intercontinentale Gallo, pp. 123-131.

García López, Jorge (1995). «Cervantes y el novellino: el ejemplo de Vidriera», en G. Grilli (ed.), Actas del II Congreso Internacional de la Asociación de Cervantistas (II CINDAC). Nápoles: Società Intercontinentale Gallo, pp. 601-608.

García Lorenzo, Luciano (2008). «Don Quijote en la escena española (2005). De la comicidad al testimonio político», en Alexia Dotras Bravo, José Manuel Lucía Megías, Elisabet Magro García y José Montero Reguera (ed.), Tus obras los rincones de la tierra descubren. Actas del VI Congreso Internacional de la Asociación de Cervantistas (VI CINDAC). Alcalá de Henares: Centro de Estudios Cervantinos, pp. 15-27.

García-Page, Mario (2001). «Un capítulo de retórica en el Quijote de Cervantes: figuras de repetición de "igualdad relajada"», en Antonio Bernat Vistarini (ed.), Volver a Cervantes. Actas del IV Congreso Internacional de la Asociación de Cervantistas (IV CINDAC). Palma de Mallorca: Universitat de les Illes Balears, I, pp. 755-763.

García-Page, Mario (1995). «El cultismo sintáctico en Cervantes», en G. Grilli (ed.), Actas del II Congreso Internacional de la Asociación de Cervantistas (II CINDAC). Nápoles: Società Intercontinentale Gallo, pp. 97-122.

García Pascual, Raquel (2004). «La peregrinación de amor en El amante liberal: amor ejemplar para una novela ejemplar», en Alicia Villar Lecumberri (ed.), Peregrinamente peregrinos. Actas del V Congreso Internacional de la Asociación de Cervantistas (V CINDAC). Palma de Mallorca: Asociación de Cervantistas, II, pp. 1347-1356. 
García Sánchez, Jairo Javier (2008). «Cordal y, en su camino, cuerdo. Probable etimología y origen de dos voces muy cervantinas», en Alexia Dotras Bravo, José Manuel Lucía Megías, Elisabet Magro García y José Montero Reguera (ed.), Tus obras los rincones de la tierra descubren. Actas del VI Congreso Internacional de la Asociación de Cervantistas (VI CINDAC). Alcalá de Henares: Centro de Estudios Cervantinos, pp. 333345.

Gaylord, Mary (2001). «El Lepanto intercalado de Don Quijote», en Antonio Bernat Vistarini (ed.), Volver a Cervantes. Actas del IV Congreso Internacional de la Asociación de Cervantistas (IV CINDAC). Palma de Mallorca: Universitat de les Illes Balears, I, pp. 35-36.

Gómez Canseco, Luis (2008). «1614: Cervantes escribe otro Quijote», en Alexia Dotras Bravo, José Manuel Lucía Megías, Elisabet Magro García y José Montero Reguera (ed.), Tus obras los rincones de la tierra descubren. Actas del VI Congreso Internacional de la Asociación de Cervantistas (VI CINDAC). Alcalá de Henares: Centro de Estudios Cervantinos, pp. 29-43.

González, Aurelio (2014). «La casa de los celos y selvas de Ardenia y la propuesta cervantina de la multiplicidad espacial», en Emilio Martínez Mata y María Fernández Ferreiro (ed.), Comentarios a Cervantes. Actas selectas del VIII Congreso Internacional de la Asociación de Cervantistas (VIII CINDAC). Madrid: Fundación María Cristina Masaveu Peterson, pp. 963-976.

González, Aurelio (2011). «Construcción y funciones del espacio dramático en las comedias de Cervantes», en Christoph Strosetzki (ed.), Visiones y revisiones cervantinas. Actas selectas del VII Congreso Internacional de la Asociación de Cervantistas (VII CINDAC). Alcalá de Henares: Centro de Estudios Cervantinos, pp. 19-36.

González, Aurelio (2001). «El manejo del espacio teatral en las comedias cervantinas», en Antonio Bernat Vistarini (ed.), Volver a Cervantes. Actas del IV Congreso Internacional de la Asociación de Cervantistas (IV CINDAC). Palma de Mallorca: Universitat de les Illes Balears, II, pp. 947-964.

González, Aurelio (1998). «El disfraz en las comedias cervantinas», en Antonio Bernat Vistarini (ed.), Actas del Tercer Congreso Internacional de la Asociación de Cervantistas (III CINDAC). Palma: Universitat de les Illes Balears, pp. 583-589.

González, Aurelio (1995). «Las acotaciones: elementos de la construcción teatral en las comedias cervantinas», en G. Grilli (ed.), Actas del II Congreso Internacional de la Asociación de Cervantistas (II CINDAC). Nápoles: Società Intercontinentale Gallo, pp. 155-169.

González Briz, María de los Ángeles (2014). «Claves de España: ficciones cervantinas en la literatura uruguaya», en Emilio Martínez Mata y María Fernández Ferreiro (ed.), Comentarios a Cervantes. Actas selectas del VIII Congreso Internacional de la Asociación de Cervantistas (VIII CINDAC). Madrid: Fundación María Cristina Masaveu Peterson, pp. 658-668.

González Maestro, Jesús (2001). «La poética de lo trágico en el teatro de Miguel de Cervantes y de Georg Büchner», en Antonio Bernat Vistarini (ed.), Volver a Cervantes. Actas del IV Congreso Internacional de la Asociación de Cervantistas (IV CINDAC). Palma de Mallorca: Universitat de les Illes Balears, II, pp. 965-982.

González Maestro, Jesús (1998). «Construcción e interpretación del diálogo en los Entremeses de Cervantes», en Antonio Bernat Vistarini (ed.), Actas del Tercer Congreso Internacional de la Asociación de Cervantistas (III CINDAC). Palma: Universitat de les Illes Balears, pp. 591-610.

Gordon, Michael (2014). «¿Una economía de la religión o una religión de la economía?: las estrategias de negocios de los mercaderes judíos de Cervantes y Shakespeare», en 
Emilio Martínez Mata y María Fernández Ferreiro (ed.), Comentarios a Cervantes. Actas selectas del VIII Congreso Internacional de la Asociación de Cervantistas (VIII CINDAC). Madrid: Fundación María Cristina Masaveu Peterson, pp. 906-911.

Gorla, Paola Laura (1998). «Representar lo real como dispersión: quiasmos y elencos en las Novelas ejemplares», en Antonio Bernat Vistarini (ed.), Actas del Tercer Congreso Internacional de la Asociación de Cervantistas (III CINDAC). Palma: Universitat de les Illes Balears, pp. 453-457.

Grilli, Giuseppe (2004). «Los peregrinos de amor en Lope y Cervantes, o sea La Galatea, Heliodoro y la voluntad de estilo», en Alicia Villar Lecumberri (ed.), Peregrinamente peregrinos. Actas del V Congreso Internacional de la Asociación de Cervantistas ( $V$ CINDAC). Palma de Mallorca: Asociación de Cervantistas, I, pp. 435-455.

Grilli, Giuseppe (ed.) (1995). Actas del II Congreso Internacional de la Asociación de Cervantistas (II CINDAC). Nápoles: Società Intercontinentale Gallo.

Güntert, Georges (2011). «La pluridiscursividad del Persiles», en Christoph Strosetzki (ed.), Visiones y revisiones cervantinas. Actas selectas del VII Congreso Internacional de la Asociación de Cervantistas (VII CINDAC). Alcalá de Henares: Centro de Estudios Cervantinos, pp. 37-50.

Gutiérrez, Carlos M. (2001). «Ironía, poeticidad y decorum en el Viaje del Parnaso», en Antonio Bernat Vistarini (ed.), Volver a Cervantes. Actas del IV Congreso Internacional de la Asociación de Cervantistas (IV CINDAC). Palma de Mallorca: Universitat de les Illes Balears, II, pp. 1043-1049.

Guzina, Nataša N. (2014). «La recepción del Quijote de Cervantes en la poesía infantil serbia a través de un ejemplo de análisis de los poemas de Dobrica Erić», en Emilio Martínez Mata y María Fernández Ferreiro (ed.), Comentarios a Cervantes. Actas selectas del VIII Congreso Internacional de la Asociación de Cervantistas (VIII CIN$D A C)$. Madrid: Fundación María Cristina Masaveu Peterson, pp. 692-701.

Hidalgo Serna, Emilio (1998). «Humanismo, retórica e ironía en el Quijote», en Antonio Bernat Vistarini (ed.), Actas del Tercer Congreso Internacional de la Asociación de Cervantistas (III CINDAC). Palma: Universitat de les Illes Balears, pp. 335-343.

Honda, Seiji (1995). «Sobre La Galatea como égloga», en G. Grilli (ed.), Actas del II Congreso Internacional de la Asociación de Cervantistas (II CINDAC). Nápoles: Società Intercontinentale Gallo, pp. 197-212.

Hutchinson, Steven (2014). «Martirologios cervantinos: acerca de la lógica del sufrimiento», en Emilio Martínez Mata y María Fernández Ferreiro (ed.), Comentarios a Cervantes. Actas selectas del VIII Congreso Internacional de la Asociación de Cervantistas (VIII CINDAC). Madrid: Fundación María Cristina Masaveu Peterson, pp. 977-985.

Hutchinson, Steven (2001). "“Haga yo lo que en mí es”: Preciosa como encarnación del valor», en Antonio Bernat Vistarini (ed.), Volver a Cervantes. Actas del IV congreso internacional de la Asociación de Cervantistas. Palma de Mallorca: Universitat de les Illes Balears, II, pp. 809-821.

Hutchinson, Steven (1998). «El valor de amar: identidad y dimensión pública del amor, en Antonio Bernat Vistarini (ed.), Actas del Tercer Congreso Internacional de la Asociación de Cervantistas (III CINDAC). Palma: Universitat de les Illes Balears, pp. 179184.

Iffland, James (1995), «La raíz festiva del cura Pero Pérez», en G. Grilli (ed.), Actas del II Congreso Internacional de la Asociación de Cervantistas (II CINDAC). Nápoles: Società Intercontinentale Gallo, pp. 353-362.

Illades Aguiar, Gustavo (2008). «"Aquellas sonadas soñadas invenciones que leía”: de la lectura susurrante de Quejana a la locura de don Quijote», en Alexia Dotras Bravo, José Manuel Lucía Megías, Elisabet Magro García y José Montero Reguera (ed.), Tus 
obras los rincones de la tierra descubren. Actas del VI Congreso Internacional de la Asociación de Cervantistas (VI CINDAC). Alcalá de Henares: Centro de Estudios Cervantinos, pp. 367-377.

Illades Aguiar, Gustavo (1995). «El honor como espectáculo en la novela del Curioso impertinente», en G. Grilli (ed.), Actas del II Congreso Internacional de la Asociación de Cervantistas (II CINDAC). Nápoles: Società Intercontinentale Gallo, pp. 487-495.

Inamoto, Kenji (1995). «Sobre un tomo del homenaje "satírico" a Cervantes», en G. Grilli (ed.), Actas del II Congreso Internacional de la Asociación de Cervantistas (II CINDAC). Nápoles: Società Intercontinentale Gallo, pp. 75-82.

Inamoto, Kenji (2004). «Sobre la atribución cervantina de La tía fingida o/y sobre el hiato delante del acento rítmico interno en el verso cervantino», en Alicia Villar Lecumberri (ed.), Peregrinamente peregrinos. Actas del V Congreso Internacional de la Asociación de Cervantistas (V CINDAC). Palma de Mallorca: Asociación de Cervantistas, II, pp. 1401-1417.

Kalenič Ramšak, Branka (2011). «La recepción eslovena de Cervantes», en Christoph Strosetzki (ed.), Visiones y revisiones cervantinas. Actas selectas del VII Congreso Internacional de la Asociación de Cervantistas (VII CINDAC). Alcalá de Henares: Centro de Estudios Cervantinos, pp. 411-420.

Lathrop, Tom (2008). «¿Se necesita otra nueva traducción del Quijote en inglés?», en Alexia Dotras Bravo, José Manuel Lucía Megías, Elisabet Magro García y José Montero Reguera (ed.), Tus obras los rincones de la tierra descubren. Actas del VI Congreso Internacional de la Asociación de Cervantistas (VI CINDAC). Alcalá de Henares: Centro de Estudios Cervantinos, pp. 385-390.

Layna Ranz, Francisco (2014). «La liebre y la jaula de grillos (Quijote, II, 73): el confesor Diego de Yepes y la salvación del alma», en Emilio Martínez Mata y María Fernández Ferreiro (ed.), Comentarios a Cervantes. Actas selectas del VIII Congreso Internacional de la Asociación de Cervantistas (VIII CINDAC). Madrid: Fundación María Cristina Masaveu Peterson, pp. 415-424.

Lauer, Robert A. (2014). «La Numancia de Cervantes y la creación de una conciencia fundacional nacional», en Emilio Martínez Mata y María Fernández Ferreiro (ed.), Comentarios a Cervantes. Actas selectas del VIII Congreso Internacional de la Asociación de Cervantistas (VIII CINDAC). Madrid: Fundación María Cristina Masaveu Peterson, pp. 986-996.

López Férez, Juan Antonio (2011). «Mitos y nombres míticos clásicos en Persiles y Sigismunda», en Christoph Strosetzki (ed.), Visiones y revisiones cervantinas. Actas selectas del VII Congreso Internacional de la Asociación de Cervantistas (VII CINDAC). Alcalá de Henares: Centro de Estudios Cervantinos, pp. 457-469.

López Férez, Juan Antonio (2008). «Presencia de autores griegos y latinos en el Quijote», en Alexia Dotras Bravo, José Manuel Lucía Megías, Elisabet Magro García y José Montero Reguera (ed.), Tus obras los rincones de la tierra descubren. Actas del VI Congreso Internacional de la Asociación de Cervantistas (VI CINDAC). Alcalá de Henares: Centro de Estudios Cervantinos, pp. 405-426.

López Navia, Santiago (2008). «Ithaca semper incognita. José María Casasayas, cervantista», en Felipe Pedraza y Rafael González Cañal (ed.), Con los pies en la tierra. Don Quijote en su marco geográfico e histórico. Homenaje a José María Casasayas (XIICIAC). Cuenca: Ediciones de la Universidad de Castilla-La Mancha, pp. 23-51.

Lozano-Renieblas, Isabel (2014). «Porque invenciones noveles, admiran, o hacen reír. La propuesta cómica de las Ejemplares», en Emilio Martínez Mata y María Fernández Ferreiro (ed.), Comentarios a Cervantes. Actas selectas del VIII Congreso Internacio- 
nal de la Asociación de Cervantistas (VIII CINDAC). Madrid: Fundación María Cristina Masaveu Peterson, pp. 46-64.

Lozano-Renieblas, Isabel (2011). «Tradición y experimentación en La española inglesa», en Christoph Strosetzki (ed.), Visiones y revisiones cervantinas. Actas selectas del VII Congreso Internacional de la Asociación de Cervantistas (VII CINDAC). Alcalá de Henares: Centro de Estudios Cervantinos, pp. 527-534.

Lozano-Renieblas, Isabel (2008). «Cervantes y el género de la novela», en Alexia Dotras Bravo, José Manuel Lucía Megías, Elisabet Magro García y José Montero Reguera (ed.), Tus obras los rincones de la tierra descubren. Actas del VI Congreso Internacional de la Asociación de Cervantistas (VI CINDAC). Alcalá de Henares: Centro de Estudios Cervantinos, pp. 441-448.

Lozano-Renieblas, Isabel (2004). "Sobre la naturaleza del discurso en el Persiles», en Alicia Villar Lecumberri (ed.), Peregrinamente peregrinos. Actas del V Congreso Internacional de la Asociación de Cervantistas (V CINDAC). Palma de Mallorca: Asociación de Cervantistas, II, pp. 483-499.

Lozano-Renieblas, Isabel (2001). «La oración de santa Apolonia y las intenciones de Sansón Carrasco: La Celestina en el Quijote», en Antonio Bernat Vistarini (ed.), Volver a Cervantes. Actas del IV Congreso Internacional de la Asociación de Cervantistas (IV CINDAC). Palma de Mallorca: Universitat de les Illes Balears, I, pp. 699-704.

Lozano-Renieblas, Isabel (1998). «La función de la écfrasis en el Persiles», en Antonio Bernat Vistarini (ed.), Actas del Tercer Congreso Internacional de la Asociación de Cervantistas (III CINDAC). Palma: Universitat de les Illes Balears, pp. 507-515.

Lucía Megías, José Manuel (2008). «Don Quijote de la Mancha, caballero andante: el acto de investidura a partir de sus imágenes», en Alexia Dotras Bravo, José Manuel Lucía Megías, Elisabet Magro García y José Montero Reguera (ed.), Tus obras los rincones de la tierra descubren. Actas del VI Congreso Internacional de la Asociación de Cervantistas (VI CINDAC). Alcalá de Henares: Centro de Estudios Cervantinos, pp. 45-85.

Luttikhuizen, Frances (2001). «Tolerancia e intolerancia en El amante liberal», en Antonio Bernat Vistarini (ed.), Volver a Cervantes. Actas del IV Congreso Internacional de la Asociación de Cervantistas (IV CINDAC). Palma de Mallorca: Universitat de les Illes Balears, II, pp. 823-826.

Mancing, Howard (2014). «El Quijote y la autopoiesis», en Emilio Martínez Mata y María Fernández Ferreiro (ed.), Comentarios a Cervantes. Actas selectas del VIII Congreso Internacional de la Asociación de Cervantistas (VIII CINDAC). Madrid: Fundación María Cristina Masaveu Peterson, pp. 460-467.

Mañero Lozano, David (2011). «Decoro literario y relaciones intertextuales en el Coloquio de los perros», en Christoph Strosetzki (ed.), Visiones y revisiones cervantinas. Actas selectas del VII Congreso Internacional de la Asociación de Cervantistas (VII CIN$D A C)$. Alcalá de Henares: Centro de Estudios Cervantinos, pp. 545-554.

Mãrculescu, Sorin (2004). «El paso por Lisboa: El mundo del Persiles como reloj de arena», en Alicia Villar Lecumberri (ed.), Peregrinamente peregrinos. Actas del V Congreso Internacional de la Asociación de Cervantistas (V CINDAC). Palma de Mallorca: Asociación de Cervantistas, II, pp. 513-530.

Mariscal, Beatriz (1998). «El Caballero de los Leones y la disputa entre Cupido y el Interés», en Antonio Bernat Vistarini (ed.), Actas del Tercer Congreso Internacional de la Asociación de Cervantistas (III CINDAC). Palma: Universitat de les Illes Balears, pp. 421-427.

Márquez Villanueva, Francisco (1995). «Sobre el contexto religioso de La Galatea», en G. Grilli (ed.), Actas del II Congreso Internacional de la Asociación de Cervantistas (II CINDAC). Nápoles: Società Intercontinentale Gallo, pp. 181-196. 
Martín, Adrienne L. (2014). «Animales quijotescos: una aproximación a los estudios de animales en Don Quijote», en Emilio Martínez Mata y María Fernández Ferreiro (ed.), Comentarios a Cervantes. Actas selectas del VIII Congreso Internacional de la Asociación de Cervantistas (VIII CINDAC). Madrid: Fundación María Cristina Masaveu Peterson, pp. 468-476.

Martín, Adrienne L. (2004). «Cervantes y la canifilia renacentista en El coloquio de los perros», en Alicia Villar Lecumberri (ed.), Peregrinamente peregrinos. Actas del V Congreso Internacional de la Asociación de Cervantistas (V CINDAC). Palma de Mallorca: Asociación de Cervantistas, II, pp. 1559-1572.

Martín Morán, José Manuel (2014). «El diálogo en el Quijote. Conflictos de competencia entre el narrador y los personajes», en Emilio Martínez Mata y María Fernández Ferreiro (ed.), Comentarios a Cervantes. Actas selectas del VIII Congreso Internacional de la Asociación de Cervantistas (VIII CINDAC). Madrid: Fundación María Cristina Masaveu Peterson, pp. 65-103.

Martín Morán, José Manuel (2008). «El tratamiento de los objetos en el Quijote y el Guzmán», en Alexia Dotras Bravo, José Manuel Lucía Megías, Elisabet Magro García y José Montero Reguera (ed.), Tus obras los rincones de la tierra descubren. Actas del VI Congreso Internacional de la Asociación de Cervantistas (VI CINDAC). Alcalá de Henares: Centro de Estudios Cervantinos, pp. 469-483.

Martín Morán, José Manuel (2004). «Identidad y alteridad en Persiles y Sigismunda», en Alicia Villar Lecumberri (ed.), Peregrinamente peregrinos. Actas del V Congreso Internacional de la Asociación de Cervantistas (V CINDAC). Palma de Mallorca: Asociación de Cervantistas, I, pp. 561-591.

Martín Morán, José Manuel (2001). «Palacio quijotista. Actitudes sensoriales en la crítica sobre el Quijote de la segunda mitad del siglo XX», en Antonio Bernat Vistarini (ed.). Volver a Cervantes. Actas del IV Congreso Internacional de la Asociación de Cervantistas (IV CINDAC). Palma de Mallorca: Universitat des Illes Ballears, I, pp. 141-194.

Martín Morán, José Manuel (1998). «La débil autoridad del padrastro del Quijote», en Antonio Bernat Vistarini (ed.), Actas del Tercer Congreso Internacional de la Asociación de Cervantistas (III CINDAC). Palma: Universitat de les Illes Balears, pp. 277295.

Martín Morán, José Manuel (1995). «La plusvalía de la palabra en el Quijote», en G. Grilli (ed.), Actas del II Congreso Internacional de la Asociación de Cervantistas (II CINDAC). Nápoles: Società Intercontinentale Gallo, pp. 275-295.

Martinengo, Alessandro (1998). «El léxico del marginalismo en la traducción al italiano, por Alfredo Giannini, de Rinconete y Cortadillo (1912)», en Antonio Bernat Vistarini (ed.), Actas del Tercer Congreso Internacional de la Asociación de Cervantistas (III CINDAC). Palma: Universitat de les Illes Balears, pp. 459-467.

Martínez Mata, Emilio, et al (2014). «Recepción e interpretación del Quijote (1605-1800). Traducciones, ediciones, opiniones», en Emilio Martínez Mata y María Fernández Ferreiro (ed.), Comentarios a Cervantes. Actas selectas del VIII Congreso Internacional de la Asociación de Cervantistas (VIII CINDAC). Madrid: Fundación María Cristina Masaveu Peterson, pp. 167-185.

Martínez Pereira, Ana (2014). «Evaluación de variantes de la primera edición del Quijote: breve historia de un cotejo», en Emilio Martínez Mata y María Fernández Ferreiro (ed.), Comentarios a Cervantes. Actas selectas del VIII Congreso Internacional de la Asociación de Cervantistas (VIII CINDAC). Madrid: Fundación María Cristina Masaveu Peterson, pp. 477-485.

Martínez Pereira, Ana y Torné, Emilio (2008). «82 pliegos + 1. Hacia la reconstrucción tipográfica de la princeps del Quijote», en Alexia Dotras Bravo, José Manuel Lucía 
Megías, Elisabet Magro García y José Montero Reguera (ed.), Tus obras los rincones de la tierra descubren. Actas del VI Congreso Internacional de la Asociación de Cervantistas (VI CINDAC). Alcalá de Henares: Centro de Estudios Cervantinos, pp. 503521.

Maspoch Bueno, Santiago (1995). «El traductor en el Quijote», en G. Grilli (ed.), Actas del II Congreso Internacional de la Asociación de Cervantistas (II CINDAC). Nápoles: Società Intercontinentale Gallo, pp. 329-333.

Mata Induráin, Carlos (2004). «Algo más sobre Cervantes poeta: a propósito de los sonetos del Persiles», en Alicia Villar Lecumberri (ed.), Peregrinamente peregrinos. Actas del V Congreso Internacional de la Asociación de Cervantistas (V CINDAC). Palma de Mallorca: Asociación de Cervantistas, II, pp. 651-675.

Matzat, Wolfgang (2004). «Peregrinación y patria en el Persiles de Cervantes», en Alicia Villar Lecumberri (ed.), Peregrinamente peregrinos. Actas del V Congreso Internacional de la Asociación de Cervantistas (V CINDAC). Palma de Mallorca: Asociación de Cervantistas, I, pp. 677-685.

Maurya, Vibha (2014). «Varios Quijotes: recepción del Quijote en las lenguas vernáculas indias», en Emilio Martínez Mata y María Fernández Ferreiro (ed.), Comentarios a Cervantes. Actas selectas del VIII Congreso Internacional de la Asociación de Cervantistas (VIII CINDAC). Madrid: Fundación María Cristina Masaveu Peterson, pp. $750-759$.

Maurya, Vibha (2008). «Traducción de El Quijote: apuntes de una traductora», en Alexia Dotras Bravo, José Manuel Lucía Megías, Elisabet Magro García y José Montero Reguera (ed.), Tus obras los rincones de la tierra descubren. Actas del VI Congreso Internacional de la Asociación de Cervantistas (VI CINDAC). Alcalá de Henares: Centro de Estudios Cervantinos, pp. 545-551.

Merkl, Heinrich (2014). «El Quijote cervantino como respuesta al Hipias menor de Platón», en Emilio Martínez Mata y María Fernández Ferreiro (ed.), Comentarios a Cervantes. Actas selectas del VIII Congreso Internacional de la Asociación de Cervantistas (VIII CINDAC). Madrid: Fundación María Cristina Masaveu Peterson, pp. 486-493.

Merkl, Heinrich (2008). «El Quijote de 1615 como respuesta cervantina al diálogo Eutidemo de Platón», en Alexia Dotras Bravo, José Manuel Lucía Megías, Elisabet Magro García y José Montero Reguera (ed.), Tus obras los rincones de la tierra descubren. Actas del VI Congreso Internacional de la Asociación de Cervantistas (VI CINDAC). Alcalá de Henares: Centro de Estudios Cervantinos, pp. 553-560.

Micozzi, Patrizia (1995). «Imágenes metafóricas en la canción a la Virgen de Guadalupe», en G. Grilli (ed.), Actas del II Congreso Internacional de la Asociación de Cervantistas (II CINDAC). Nápoles: Società Intercontinentale Gallo, pp. 711-723.

Mierau, Konstantin (2011). «¿Cómo se escribe la liminalidad? La caracterización de Don Juan en La gitanilla y un concepto teórico», en Christoph Strosetzki (ed.), Visiones y revisiones cervantinas. Actas selectas del VII Congreso Internacional de la Asociación de Cervantistas (VII CINDAC). Alcalá de Henares: Centro de Estudios Cervantinos, pp. 603-615.

Molho, Maurice (1995). «Filosofía natural o filosofía racional: sobre el concepto de astrología en los Trabajos de Persiles y Sigismunda», en G. Grilli (ed.), Actas del II Congreso Internacional de la Asociación de Cervantistas (II CINDAC). Nápoles: Società Intercontinentale Gallo, pp. 673-679.

Moner, Michel (2004). «En los confines de la especie: fieras, monstruos y bichos raros en Los trabajos de Persiles y Sigismunda», en Alicia Villar Lecumberri (ed.), Peregrina- 
mente peregrinos. Actas del $V$ Congreso Internacional de la Asociación de Cervantistas (V CINDAC). Palma de Mallorca: Asociación de Cervantistas, I, pp. 703-720.

Moner, Michel (1998). «El engendramiento del personaje en la narrativa cervantina», en Antonio Bernat Vistarini (ed.), Actas del Tercer Congreso Internacional de la Asociación de Cervantistas (III CINDAC). Palma: Universitat de les Illes Balears, pp. 43-48.

Montcher, Fabian (2011). «La española inglesa de Cervantes en su contexto historiográfico», en Christoph Strosetzki (ed.), Visiones y revisiones cervantinas. Actas selectas del VII Congreso Internacional de la Asociación de Cervantistas (VII CINDAC). Alcalá de Henares: Centro de Estudios Cervantinos, pp. 617-627.

Montero Reguera, José, et al (2014). «La edición de la poesía de Miguel de Cervantes», en Emilio Martínez Mata y María Fernández Ferreiro (ed.), Comentarios a Cervantes. Actas selectas del VIII Congreso Internacional de la Asociación de Cervantistas (VIII CINDAC). Madrid: Fundación María Cristina Masaveu Peterson, pp. 124-138.

Montero Reguera, José (2011). «Trayectoria del epitafio en la poesía cervantina (I)», en Christoph Strosetzki (ed.), Visiones y revisiones cervantinas. Actas selectas del VII Congreso Internacional de la Asociación de Cervantistas (VII CINDAC). Alcalá de Henares: Centro de Estudios Cervantinos, pp. 629-637.

Montero Reguera, José (2004a). «Entre tantos adioses: una nota sobre la despedida cervantina del Persiles», en Alicia Villar Lecumberri (ed.), Peregrinamente peregrinos. Actas del V Congreso Internacional de la Asociación de Cervantistas (V CINDAC). Palma de Mallorca: Asociación de Cervantistas, I, pp. 721-735.

Montero Reguera, José (2004b). «Palabras en la clausura del XI Coloquio Internacional de la Asociación de Cervantistas (Seúl, 20 de noviembre de 2004)», Boletín de la Asociación de Cervantistas. I.2, pp. 47-48.

Montero Reguera, José (2004c). «Salutación del optimista», Boletín de la Asociación de Cervantistas. I.1, p. 5-6.

Montero Reguera, José (2004d). «Hasta siempre, Casasayas», Anales Cervantinos. 36, pp. 13-14.

Montero Reguera, José (2001). «La crítica sobre el Quijote en la primera mitad del siglo XX», en Antonio Bernat Vistarini (ed.), Volver a Cervantes. Actas del IV Congreso Internacional de la Asociación de Cervantistas (IV CINDAC). Palma de Mallorca: Universitat de les Illes Balears, I, pp. 195-236.

Montero Reguera, José (1998). «Hacia una revisión de las atribuciones teatrales cervantinas: La soberana Virgen de Guadalupe, y sus milagros, y grandeças de España», en Antonio Bernat Vistarini (ed.), Actas del Tercer Congreso Internacional de la Asociación de Cervantistas (III CINDAC). Palma: Universitat de les Illes Balears, pp. 611617.

Morales, Ángela (2014). «Nuevas consideraciones sobre el personaje de don Diego Miranda: la identidad religiosa del Caballero del Verde Gabán», en Emilio Martínez Mata y María Fernández Ferreiro (ed.), Comentarios a Cervantes. Actas selectas del VIII Congreso Internacional de la Asociación de Cervantistas (VIII CINDAC). Madrid: Fundación María Cristina Masaveu Peterson, pp. 494-503.

Morales, Ángela (2001). «Lengua y poder: una lectura sociolingüística del Quijote», en Antonio Bernat Vistarini (ed.), Volver a Cervantes. Actas del IV Congreso Internacional de la Asociación de Cervantistas (IV CINDAC). Palma de Mallorca: Universitat de les Illes Balears, I, pp. 765-770.

Moreno, Lola (2008). «La presencia del Quijote en la prensa diaria (2005-2006): lecturas, versiones, manipulaciones y recreaciones», en Alexia Dotras Bravo, José Manuel Lucía Megías, Elisabet Magro García y José Montero Reguera (ed.), Tus obras los rincones de la tierra descubren. Actas del VI Congreso Internacional de la Asociación de Cer- 
vantistas (VI CINDAC). Alcalá de Henares: Centro de Estudios Cervantinos, pp. 561575.

Morón Arroyo, Ciriaco (1995). «Ver, oír: Sancho sentido», en G. Grilli (ed.), Actas del II Congreso Internacional de la Asociación de Cervantistas (II CINDAC). Nápoles: Società Intercontinentale Gallo, pp. 335-346.

Neumeister, Sebastián (1995). «Los encantadores y la realidad del mundo de don Quijote», en G. Grilli (ed.), Actas del II Congreso Internacional de la Asociación de Cervantistas (II CINDAC). Nápoles: Società Intercontinentale Gallo, pp. 297-305.

Nishida, Enma (2008). «Los romances y el lenguaje de germanía en el Entremés del Rufián viudo: ¿mensajes pícaros de Cervantes hacia Alonso Fernández de Avellaneda?», en Alexia Dotras Bravo, José Manuel Lucía Megías, Elisabet Magro García y José Montero Reguera (ed.), Tus obras los rincones de la tierra descubren. Actas del VI Congreso Internacional de la Asociación de Cervantistas (VI CINDAC). Alcalá de Henares: Centro de Estudios Cervantinos, pp. 591-599.

Ohanna, Natalio (2014). «La sacralización del cautiverio argelino», en Emilio Martínez Mata y María Fernández Ferreiro (ed.), Comentarios a Cervantes. Actas selectas del VIII Congreso Internacional de la Asociación de Cervantistas (VIII CINDAC). Madrid: Fundación María Cristina Masaveu Peterson, pp. 997-1004.

Olid Guerrero, Eduardo (2014). «“¡Como si tuviese más letras un no que un sí!”: violencia en Rinconete y Cortadillo», en Emilio Martínez Mata y María Fernández Ferreiro (ed.), Comentarios a Cervantes. Actas selectas del VIII Congreso Internacional de la Asociación de Cervantistas (VIII CINDAC). Madrid: Fundación María Cristina Masaveu Peterson, pp. 912-921.

Önalp, Ertugrul (2004). «¿Es cierta la imagen de Dragut reflejada en el Persiles?», en Alicia Villar Lecumberri (ed.), Peregrinamente peregrinos. Actas del V Congreso Internacional de la Asociación de Cervantistas (V CINDAC). Palma de Mallorca: Asociación de Cervantistas, I, pp. 753-766.

Pabón, Tomás (1995). «Cardenio en Cervantes, Shakespeare y Fletcher», en G. Grilli (ed.), Actas del II Congreso Internacional de la Asociación de Cervantistas (II CINDAC). Nápoles: Società Intercontinentale Gallo, pp. 371-378.

Palazón M., María Rosa (2004). «Travesuras de la carne o las sospechas de Clodio», en Alicia Villar Lecumberri (ed.), Peregrinamente peregrinos. Actas del V Congreso Internacional de la Asociación de Cervantistas (V CINDAC). Palma de Mallorca: Asociación de Cervantistas, I, pp. 767-789.

Park, Chul (2005). «El hispanismo en Corea y la recepción del Quijote en Corea», en «In memoriam José María Casasayas». Actas del XI Coloquio Internacional de la Asociación de Cervantistas (XI CIAC). Seúl: Universidad Hankuk de Estudios Extranjeros, pp. 1-15.

Park, Chul (2001). «La república bien ordenada en el mundo literario de Cervantes», en Antonio Bernat Vistarini (ed.), Volver a Cervantes. Actas del IV Congreso Internacional de la Asociación de Cervantistas (IV CINDAC). Palma de Mallorca: Universitat de les Illes Balears, I, pp. 327-339.

Parodi de Geltman, Alicia (2004). «San Pablo, o quien solo Dios sabe, en el Persiles», en Alicia Villar Lecumberri (ed.), Peregrinamente peregrinos. Actas del V Congreso Internacional de la Asociación de Cervantistas (V CINDAC). Palma de Mallorca: Asociación de Cervantistas, I, pp. 807-818.

Parodi de Geltman, Alicia (2001). «Lepanto en las Ejemplares», en Antonio Bernat Vistarini (ed.), Volver a Cervantes. Actas del IV Congreso Internacional de la Asociación de Cervantistas (IV CINDAC). Palma de Mallorca: Universitat de les Illes Balears, I, pp. 47-52. 
Parodi de Geltman, Alicia (1998). «¿Quién es éste?: la inverosímil identidad de Tomás Rueda, sus círculos y bifurcaciones», en Antonio Bernat Vistarini (ed.), Actas del Tercer Congreso Internacional de la Asociación de Cervantistas (III CINDAC). Palma: Universitat de les Illes Balears, pp. 469-480.

Parodi de Geltman, Alicia (1995). «La estructura alegórica del Quijote de 1605», en G. Grilli (ed.), Actas del II Congreso Internacional de la Asociación de Cervantistas (II CINDAC). Nápoles: Società Intercontinentale Gallo, pp. 431-446.

Parodi, Alicia, D’Onofrio, Julia y Vila, Juan Diego (ed.) (2006). El «Quijote» en Buenos Aires. Lecturas cervantinas en el cuarto centenario. Buenos Aires: Instituto de Filología y Literaturas Hispánicas «Dr. Amado Alonso» de la Facultad de Filosofía y Letras de la Universidad de Buenos Aires y Asociación de Cervantistas.

Pastrana Santamarta, Tomasa (2014). «La parodia del atuendo en el Quijote», en Emilio Martínez Mata y María Fernández Ferreiro (ed.), Comentarios a Cervantes. Actas selectas del VIII Congreso Internacional de la Asociación de Cervantistas (VIII CIN$D A C)$. Madrid: Fundación María Cristina Masaveu Peterson, pp. 518-527.

Pedraza Jiménez, Felipe (2008). «Un nuevo coloquio, no un coloquio más», en Felipe Pedraza y Rafael González Cañal (ed.), Con los pies en la tierra. Don Quijote en su marco geográfico e histórico. Homenaje a José María Casasayas (XII-CIAC). Cuenca: Ediciones de la Universidad de Castilla-La Mancha, pp. 13-14.

Percas de Ponseti, Helena (2004). «Adiós a José María Casasayas, organizador genial». Bulletin of the Cervantes Society of America. 24.2, pp. 189-93.

Pérez Rodríguez, Marta (2011). «Don Quijote, Sancho y Dulcinea: mosaico brasileño de personajes cervantinos construido por Nelson Omegna», en Christoph Strosetzki (ed.), Visiones y revisiones cervantinas. Actas selectas del VII Congreso Internacional de la Asociación de Cervantistas (VII CINDAC). Alcalá de Henares: Centro de Estudios Cervantinos, pp. 727-734.

Piñero Valverde, José (2008). «El primer ensayo de José Gaos sobre el Quijote», en Alexia Dotras Bravo, José Manuel Lucía Megías, Elisabet Magro García y José Montero Reguera (ed.), Tus obras los rincones de la tierra descubren. Actas del VI Congreso Internacional de la Asociación de Cervantistas (VI CINDAC). Alcalá de Henares: Centro de Estudios Cervantinos, pp. 611-622.

Piras, Pina Rosa (2001). «Cervantes: la Información en Argel entre ficción y documento», en Antonio Bernat Vistarini (ed.), Volver a Cervantes. Actas del IV Congreso Internacional de la Asociación de Cervantistas (IV CINDAC). Palma de Mallorca: Universitat de les Illes Balears, I, pp. 123-130.

Piskunova, Svetlana (1998). «El Quijote y los libros de caballerías: los límites de la parodia», en Antonio Bernat Vistarini (ed.), Actas del Tercer Congreso Internacional de la Asociación de Cervantistas (III CINDAC). Palma: Universitat de les Illes Balears, pp. 347-350.

Porqueras Mayo, Alberto (2001). «Claudia Jerónima (Quijote II, cap. 60). Celos a través de tradiciones culturales, técnicas pictóricas y emblemáticas», en Antonio Bernat Vistarini (ed.), Volver a Cervantes. Actas del IV Congreso Internacional de la Asociación de Cervantistas (IV CINDAC). Palma de Mallorca: Universitat de les Illes Balears, I, pp. 715-721.

Porqueras Mayo, Alberto (1998). «Los prologuillos internos del Quijote II», en Antonio Bernat Vistarini (ed.), Actas del Tercer Congreso Internacional de la Asociación de Cervantistas (III CINDAC). Palma: Universitat de les Illes Balears, pp. 297-304.

Profeti, María Grazia (2001). «Apolo, su Laurel, y el Viaje del Parnaso», en Antonio Bernat Vistarini (ed.), Volver a Cervantes. Actas del IV Congreso Internacional de la 
Asociación de Cervantistas (IV CINDAC). Palma de Mallorca: Universitat de les Illes Balears, II, pp. 1051-1061.

Quinziano, Franco (2014). «Ecos del Quijote en la Italia del siglo XVIII: una aproximación al Quijote a través de los escritos de los jesuitas expulsos», en Emilio Martínez Mata y María Fernández Ferreiro (ed.), Comentarios a Cervantes. Actas selectas del VIII Congreso Internacional de la Asociación de Cervantistas (VIII CINDAC). Madrid: Fundación María Cristina Masaveu Peterson, pp. 782-795.

Redondo, Agustín (2004). «El Persiles, "libro de entretenimiento peregrino"», en Alicia Villar Lecumberri (ed.), Peregrinamente peregrinos. Actas del V Congreso Internacional de la Asociación de Cervantistas (V CINDAC). Palma de Mallorca: Asociación de Cervantistas, I, pp. 67-102.

Redondo, Agustín (1998). «Fiestas burlescas en el palacio ducal: el episodio de Altisidora», en Antonio Bernat Vistarini (ed.), Actas del Tercer Congreso Internacional de la Asociación de Cervantistas (III CINDAC). Palma: Universitat de les Illes Balears, pp. 4962.

Redondo, Agustín (1995). «Nuevas consideraciones sobre el personaje del "Caballero del Verde Gabán” (II, 16-18)», en G. Grilli (ed.), Actas del II Congreso Internacional de la Asociación de Cervantistas (II CINDAC). Nápoles: Società Intercontinentale Gallo, pp. 513-533.

Rey Hazas, Antonio (2008). «La palabra "católico": cronología y afanes cortesanos en la obra última de Cervantes», en Alexia Dotras Bravo, José Manuel Lucía Megías, Elisabet Magro García y José Montero Reguera (ed.), Tus obras los rincones de la tierra descubren. Actas del VI Congreso Internacional de la Asociación de Cervantistas (VI CINDAC). Alcalá de Henares: Centro de Estudios Cervantinos, pp. 87-133.

Ricapito, Joseph V. (2001). «Cervantes, Lepanto, el cuerpo y el sufrimiento físico», en Antonio Bernat Vistarini (ed.), Volver a Cervantes. Actas del IV Congreso Internacional de la Asociación de Cervantistas (IV CINDAC). Palma de Mallorca: Universitat de les Illes Balears, II, pp. 53-63.

Rico, Francisco (2014). «Los nuevos textos del Quijote», en Emilio Martínez Mata y María Fernández Ferreiro (ed.), Comentarios a Cervantes. Actas selectas del VIII Congreso Internacional de la Asociación de Cervantistas (VIII CINDAC). Madrid: Fundación María Cristina Masaveu Peterson, pp. 26-45.

Rico, Francisco (1998). «Componedores y grafías en el Quijote de 1604 (Sobre un libro de R. M. Flores)», en Antonio Bernat Vistarini (ed.), Actas del Tercer Congreso Internacional de la Asociación de Cervantistas (III CINDAC). Palma: Universitat de les Illes Balears, pp. 63-83.

Riley, Edward C. (1998). «¿Cómo era Pasamonte?», en Antonio Bernat Vistarini (ed.), Actas del Tercer Congreso Internacional de la Asociación de Cervantistas (III CIN$D A C)$. Palma: Universitat de les Illes Balears, pp. 85-96.

Roca Mussons, María (1995). «La risa del arbitrista en el Coloquio de los perros», en G. Grilli (ed.), Actas del II Congreso Internacional de la Asociación de Cervantistas (II CINDAC). Nápoles: Società Intercontinentale Gallo, pp. 609-616.

Rodríguez, Alberto (1998). «Notas sobre el retrato literario en el Quijote», en Antonio Bernat Vistarini (ed.), Actas del Tercer Congreso Internacional de la Asociación de Cervantistas (III CINDAC). Palma: Universitat de les Illes Balears, pp. 409-416.

Rodríguez Luis, Julio (1998). «Una pícara cervantina», en Antonio Bernat Vistarini (ed.), Actas del Tercer Congreso Internacional de la Asociación de Cervantistas (III CIN$D A C$ ). Palma: Universitat de les Illes Balears, pp. 481487.

Rodríguez Mansilla, Fernando (2011). «Escarramán y la germanía cervantina en El rufián viudo», en Christoph Strosetzki (ed.), Visiones y revisiones cervantinas. Actas selectas 
del VII Congreso Internacional de la Asociación de Cervantistas (VII CINDAC). Alcalá de Henares: Centro de Estudios Cervantinos, pp. 777-786.

Roig, Adrien (2004). «De la vida de Manuel de Sousa Coutinho al "triste y no imaginado suceso" del portugués que murió de amor en el Persiles», en Alicia Villar Lecumberri (ed.), Peregrinamente peregrinos. Actas del V Congreso Internacional de la Asociación de Cervantistas ( $V$ CINDAC). Palma de Mallorca: Asociación de Cervantistas, I, pp. 879-898.

Roig, Adrien (1995). «Originalidad del episodio catalán del Quijote», en G. Grilli (ed.), Actas del II Congreso Internacional de la Asociación de Cervantistas (II CINDAC). Nápoles: Società Intercontinentale Gallo, pp. 535-546.

Rojas Otálora, Jorge E. (2001). «El camino de la vida como elemento estructural en El casamiento engañoso y Coloquio de los perros, de Miguel de Cervantes», en Antonio Bernat Vistarini (ed.). Volver a Cervantes. Actas del IV Congreso Internacional de la Asociación de Cervantistas (IV CINDAC). Palma de Mallorca: Universitat des Illes Ballears, II, pp. 841-845.

Rolfes, Anne (2014). «Matrimonio y locura en los entremeses cervantinos», en Emilio Martínez Mata y María Fernández Ferreiro (ed.), Comentarios a Cervantes. Actas selectas del VIII Congreso Internacional de la Asociación de Cervantistas (VIII CIN$D A C)$. Madrid: Fundación María Cristina Masaveu Peterson, pp. 1016-1026.

Romanos, Melchora (1995). «La estructura narrativa de La Galatea de Cervantes: de lo poético a la ficcionalización novelada», en G. Grilli (ed.), Actas del II Congreso Internacional de la Asociación de Cervantistas (II CINDAC). Nápoles: Società Intercontinentale Gallo, pp. 171-179.

Romera Pintor, Irene (2001). «Reminiscencias italianas en una Comedia de Cervantes: $L a$ Casa de los celos y Selvas de Ardenia», en Antonio Bernat Vistarini (ed.), Volver a Cervantes. Actas del IV Congreso Internacional de la Asociación de Cervantistas (IV CINDAC). Palma de Mallorca: Universitat de les Illes Balears, II, pp. 1015-1020.

Romero Muñoz, Carlos (2004). «Genio y figura de Teresa Panza», en Alicia Villar Lecumberri (ed.), Peregrinamente peregrinos. Actas del V Congreso Internacional de la Asociación de Cervantistas (V CINDAC). Palma de Mallorca: Asociación de Cervantistas, I, pp. 103-148.

Romero Muñoz, Carlos (2001). «Las "luengas colas de caballos" turcas», en Antonio Bernat Vistarini (ed.), Volver a Cervantes. Actas del IV Congreso Internacional de la Asociación de Cervantistas (IV CINDAC). Palma de Mallorca: Universitat de les Illes Balears, II, pp. 921-934.

Romero Muñoz, Carlos (1995). «Novelas ejemplares. Los paratextos y La gitanilla: cuestiones ecdóticas», en G. Grilli (ed.), Actas del II Congreso Internacional de la Asociación de Cervantistas (II CINDAC). Nápoles: Società Intercontinentale Gallo, pp. 549568.

Romo Feito, Fernando (2008). «Cervantes en Hegel», en Alexia Dotras Bravo, José Manuel Lucía Megías, Elisabet Magro García y José Montero Reguera (ed.), Tus obras los rincones de la tierra descubren. Actas del VI Congreso Internacional de la Asociación de Cervantistas (VI CINDAC). Alcalá de Henares: Centro de Estudios Cervantinos, pp. 647-655.

Romo Feito, Fernando (2001). «Cervantes ante la palabra lírica», en Antonio Bernat Vistarini (ed.), Volver a Cervantes. Actas del IV Congreso Internacional de la Asociación de Cervantistas (IV CINDAC). Palma de Mallorca: Universitat de les Illes Balears, II, pp. 1063-1088. 
Rossi, Rosa (1998). «Una nueva visión del heroísmo cervantino», en Antonio Bernat Vistarini (ed.), Actas del Tercer Congreso Internacional de la Asociación de Cervantistas (III CINDAC). Palma: Universitat de les Illes Balears, pp. 163-170.

Rosucci, Gabriela (1995). "Corrientes platónicas y neoplatónicas en La Galatea», en G. Grilli (ed.), Actas del II Congreso Internacional de la Asociación de Cervantistas (II CINDAC). Nápoles: Società Intercontinentale Gallo, pp. 213-222.

Rubiera, Javier (2001). «Algunos aspectos de la construcción del espacio teatral en tres comedias de cautivos: El gallardo español, Los baños de Argel y La gran sultana», en Antonio Bernat Vistarini (ed.), Volver a Cervantes. Actas del IV Congreso Internacional de la Asociación de Cervantistas (IV CINDAC). Palma de Mallorca: Universitat de les Illes Balears, II, pp. 1021-1034.

Ruffinatto, Aldo (2004). «El narrador agotado y los horizontes de expectativas del Persiles», en Alicia Villar Lecumberri (ed.), Peregrinamente peregrinos. Actas del V Congreso Internacional de la Asociación de Cervantistas (V CINDAC). Palma de Mallorca: Asociación de Cervantistas, I, pp. 899-909.

Rull, Enrique (2004). «En torno a un episodio del Persiles: Ruperta y Croriano», en Alicia Villar Lecumberri (ed.), Peregrinamente peregrinos. Actas del V Congreso Internacional de la Asociación de Cervantistas (V CINDAC). Palma de Mallorca: Asociación de Cervantistas, I, pp. 931-946.

Ruta, María Caterina (1995). «Los retratos femeninos en la segunda parte del Quijote», en G. Grilli (ed.), Actas del II Congreso Internacional de la Asociación de Cervantistas (II CINDAC). Nápoles: Società Intercontinentale Gallo, pp. 497-511.

Sabik, Kazimierz (2001). «La evolución del teatro cervantino: teoría y práctica (comedias)», en Antonio Bernat Vistarini (ed.), Volver a Cervantes. Actas del IV Congreso Internacional de la Asociación de Cervantistas (IV CINDAC). Palma de Mallorca: Universitat de les Illes Balears, II, pp. 1035-1040.

Sáez, Adrián J. (2014). «Entre Pedros anda el juego: las reescrituras de Cervantes, Pérez de Montalbán y Salas Barbadillo», en El Donoso escrutinio. Blog de lecturas, libros y ctividades de la Asociación de Cervantistas. «Cervantes por Venecia». Accesible en: http://eldonosoescrutinio.wordpress.com/2014/09/02/cervantes-por-venecia/ $(22 / 9 / 2014)$

Salgado, Ofelia (2014). «"Vitrea fracta” (Petronio, Satiricón, 10.1) y El Licenciado Vidriera», en Emilio Martínez Mata y María Fernández Ferreiro (ed.), Comentarios a Cervantes. Actas selectas del VIII Congreso Internacional de la Asociación de Cervantistas (VIII CINDAC). Madrid: Fundación María Cristina Masaveu Peterson, pp. 922-931.

Salgado, Ofelia (2004). «Hipólito/Hipólita (Persiles IV, 7): Juego de opuestos y evolución literaria», en Alicia Villar Lecumberri (ed.), Peregrinamente peregrinos. Actas del V Congreso Internacional de la Asociación de Cervantistas (V CINDAC). Palma de Mallorca: Asociación de Cervantistas, I, pp. 947-955.

Sansone, Giuseppe (1995). «El Viaje del Parnaso: testimonio de una discontinuidad», en G. Grilli (ed.), Actas del II Congreso Internacional de la Asociación de Cervantistas (II CINDAC). Nápoles: Società Intercontinentale Gallo, pp. 57-64.

Scaramuzza Vidoni, Mariarosa (2011). «Retraducciones del Quijote para la juventud en Italia a comienzos del siglo XX», en Christoph Strosetzki (ed.), Visiones y revisiones cervantinas. Actas selectas del VII Congreso Internacional de la Asociación de Cervantistas (VII CINDAC). Alcalá de Henares: Centro de Estudios Cervantinos, pp. 833843.

Sierra Macarrón, Leonor (2001). «Escribir y leer para otros: Figuras del analfabetismo en el texto cervantino», en Antonio Bernat Vistarini (ed.), Volver a Cervantes. Actas del 
IV congreso internacional de la Asociación de Cervantistas. Palma de Mallorca: Universitat de les Illes Balears, I, pp. 387-400.

Sliwa, Krzysztof (2001). «La supuesta hidalguía de Rodrigo de Cervantes, padre del autor del Quijote», en Antonio Bernat Vistarini (ed.), Volver a Cervantes. Actas del IV Congreso Internacional de la Asociación de Cervantistas (IV CINDAC). Palma de Mallorca: Universitat de les Illes Balears, I, pp. 131-138.

Soupault Rouane, Isabelle (2004). «Peregrinar por las islas: el relato insular en el Persiles», en Antonio Bernat Vistarini (ed.), Volver a Cervantes. Actas del IV congreso internacional de la Asociación de Cervantistas. Palma de Mallorca: Universitat de les Illes Balears, I, pp. 1001-1016.

Stoopen de Morfin, María (2001). «El amplio espectro de la tríada autores, libro, lectores en el Quijote», en Antonio Bernat Vistarini (ed.), Volver a Cervantes. Actas del IV Congreso Internacional de la Asociación de Cervantistas (IV CINDAC). Palma de Mallorca: Universitat de les Illes Balears, I, pp. 545-549.

Stoopen de Morfin, María (1998). «El prólogo y la dedicatoria del Quijote de 1615: la autoría enmascarada y la lectura cómplice», en Antonio Bernat Vistarini (ed.), Actas del Tercer Congreso Internacional de la Asociación de Cervantistas (III CINDAC). Palma: Universitat de les Illes Balears, pp. 305-312.

Stoopen de Morfin, María (1995). «El placer de la burla. Un lector colaborador del Quijote», en G. Grilli (ed.), Actas del II Congreso Internacional de la Asociación de Cervantistas (II CINDAC). Nápoles: Società Intercontinentale Gallo, pp. 387-394.

Suárez, Silvia B. (2004). «Hibridización en Los trabajos de Persiles y Sigismunda», en Alicia Villar Lecumberri (ed.), Peregrinamente peregrinos. Actas del V Congreso Internacional de la Asociación de Cervantistas (V CINDAC). Palma de Mallorca: Asociación de Cervantistas, I, pp. 1047-1069.

Suárez Miramón, Ana (2011). «Procedimientos para introducir la pintura en El Persiles», en Christoph Strosetzki (ed.), Visiones y revisiones cervantinas. Actas selectas del VII Congreso Internacional de la Asociación de Cervantistas (VII CINDAC). Alcalá de Henares: Centro de Estudios Cervantinos, pp. 867-878.

Suárez Miramón, Ana (2004). «Visualización teatral y alegórica en el Persiles», en Alicia Villar Lecumberri (ed.), Peregrinamente peregrinos. Actas del V Congreso Internacional de la Asociación de Cervantistas (V CINDAC). Palma de Mallorca: Asociación de Cervantistas, I, pp. 1027-1046.

Suzuki, Masashi (2014). «¿Existe una influencia del cuento pastoril en el episodio del funeral de Grisóstomo?», en Emilio Martínez Mata y María Fernández Ferreiro (ed.), Comentarios a Cervantes. Actas selectas del VIII Congreso Internacional de la Asociación de Cervantistas (VIII CINDAC). Madrid: Fundación María Cristina Masaveu Peterson, pp. 554-564.

Tomita, Hiroki (2014). «Don Quijote y sus andanzas en la narrativa japonesa: recepción y reconstrucción», en Emilio Martínez Mata y María Fernández Ferreiro (ed.), Comentarios a Cervantes. Actas selectas del VIII Congreso Internacional de la Asociación de Cervantistas (VIII CINDAC). Madrid: Fundación María Cristina Masaveu Peterson, pp. 835-843.

Torres Martínez, José Carlos de (2011). «Correspondencia cervantina de D. Alberto Sánchez. II», Anales Cervantinos. 43, pp. 245-269.

Torres Martínez, José Carlos de (2010). «Correspondencia cervantina de D. Alberto Sánchez. I», Anales Cervantinos. 42, pp. 277-304.

Torres Martínez, José Carlos de (2008). «La empresa romántica de la Asociación de Cervantistas», en Felipe B. Pedraza Jiménez y Rafael González Cañal (ed.), Con los pies en la tierra. Don Quijote en su marco geográfico e histórico (Homenaje a José María 
Casasayas) (XII-CIAC). Cuenca: Ediciones de la Universidad de Castilla-La Mancha, pp. 53-68.

Urbina, Eduardo (2001). «Hacia una edición variorum textual y crítica del Quijote», en Antonio Bernat Vistarini (ed.), Volver a Cervantes. Actas del IV Congreso Internacional de la Asociación de Cervantistas (IV CINDAC). Palma de Mallorca: Universitat de les Illes Balears, I, pp. 451-468.

Urbina, Eduardo (1998). «Dulce mi enemiga: la transformación paródica de un motivo cortesano-caballeresco en el Quijote», en Antonio Bernat Vistarini (ed.), Actas del Tercer Congreso Internacional de la Asociación de Cervantistas (III CINDAC). Palma: Universitat de les Illes Balears, pp. 351-359.

Uriarte Rebaudi, Lía Noemí (2004). «Lisboa y sus gentes en el Persiles de Cervantes», en Alicia Villar Lecumberri (ed.), Peregrinamente peregrinos. Actas del V Congreso Internacional de la Asociación de Cervantistas (V CINDAC). Palma de Mallorca: Asociación de Cervantistas, I, pp. 1071-1080.

Valdés Rodríguez, M. Cristina (2014). «Las voces femeninas de los Quijotes ingleses del siglo XVIII», en Emilio Martínez Mata y María Fernández Ferreiro (ed.), Comentarios a Cervantes. Actas selectas del VIII Congreso Internacional de la Asociación de Cervantistas (VIII CINDAC). Madrid: Fundación María Cristina Masaveu Peterson, pp. 856-871.

Vargas Díaz-Toledo, Aurelio (2011). «Presencia del Quijote en Portugal: noticia de un documento inédito», en Christoph Strosetzki (ed.), Visiones y revisiones cervantinas. Actas selectas del VII Congreso Internacional de la Asociación de Cervantistas (VII CINDAC). Alcalá de Henares: Centro de Estudios Cervantinos, pp. 889-898.

Vila, Juan Diego (1995). «Gelasia, Anaxárate y la Flor de Gnido: ejemplaridad mítica y reminiscencias garcilasianas en el final de La Galatea», en G. Grilli (ed.), Actas del II Congreso Internacional de la Asociación de Cervantistas (II CINDAC). Nápoles: Società Intercontinentale Gallo, pp. 243-258.

Vila, Juan Diego (2001). «Claudia Jerónima, mujer que mata: Género y violencia al final del Quijote de 1615», en Antonio Bernat Vistarini (ed.), Volver a Cervantes. Actas del IV Congreso Internacional de la Asociación de Cervantistas (IV CINDAC). Palma de Mallorca: Universitat de les Illes Balears, I, pp. 737-751.

Villanueva Fernández, Juan Manuel (2008). «Américo Castro, Cervantes y el erasmismo», en Alexia Dotras Bravo, José Manuel Lucía Megías, Elisabet Magro García y José Montero Reguera (ed.), Tus obras los rincones de la tierra descubren. Actas del VI Congreso Internacional de la Asociación de Cervantistas (VI CINDAC). Alcalá de Henares: Centro de Estudios Cervantinos, pp. 775-787.

Villar Lecumberri, Alicia (2014). «Los viajes de Odiseo y don Quijote», en Emilio Martínez Mata y María Fernández Ferreiro (ed.), Comentarios a Cervantes. Actas selectas del VIII Congreso Internacional de la Asociación de Cervantistas (VIII CINDAC). Madrid: Fundación María Cristina Masaveu Peterson, pp. 882-893.

Villar Lecumberri, Alicia (2011). «Don Quijote en el teatro griego actual», en Christoph Strosetzki (ed.), Visiones y revisiones cervantinas. Actas selectas del VII Congreso Internacional de la Asociación de Cervantistas (VII CINDAC). Alcalá de Henares: Centro de Estudios Cervantinos, pp. 921-937.

Vita, Sergio Fabián (1998). «El espacio mítico en la novela de El celoso extremeño», en Antonio Bernat Vistarini (ed.), Actas del Tercer Congreso Internacional de la Asociación de Cervantistas (III CINDAC). Palma: Universitat de les Illes Balears, pp. 495503.

Wheaton, Mark (2004). «El Renato del Persiles: paralelos con la conversión religiosa de San Pablo y don Quijote», en Alicia Villar Lecumberri (ed.), Peregrinamente peregri- 
nos. Actas del V Congreso Internacional de la Asociación de Cervantistas (V CIN$D A C$ ). Palma de Mallorca: Asociación de Cervantistas, I, pp. 1081-1088.

Williamson, Edwin (2014). «De un 'mundo al revés' a un 'mundo nuevo': la prolongación de la Segunda Parte del Quijote y sus consecuencias», en Emilio Martínez Mata y María Fernández Ferreiro (ed.), Comentarios a Cervantes. Actas selectas del VIII Congreso Internacional de la Asociación de Cervantistas (VIII CINDAC). Madrid: Fundación María Cristina Masaveu Peterson, pp. 104-121.

Zamora Calvo, María Jesús (2004). «Voces con eco. Rasgos tradicionales en los cuentos del Persiles», en Alicia Villar Lecumberri (ed.), Peregrinamente peregrinos. Actas del $V$ Congreso Internacional de la Asociación de Cervantistas (V CINDAC). Palma de Mallorca: Asociación de Cervantistas, I, pp. 1089-1107.

Recibido: 29 de septiembre de 2014 Aceptado: 14 de diciembre de 2014

\begin{abstract}
Resumen
Con motivo del vigésimo quinto aniversario de creación de la Asociación de Cervantistas un importante número de investigadores ha querido ofrecer una síntesis de la aportación de aquella al hispanismo. Este dossier incluye las evocaciones de algunos de quienes intervinieron en su creación, como también de sus dos primeros presidentes, Alberto Sánchez y José María Casasayas; un análisis y valoración de sus reuniones académicas y de las muchas publicaciones derivadas de ellas, y un avance de sus objetivos y proyectos inmediatos.
\end{abstract}

Palabras clave: Asociación de Cervantistas; Cervantismo; Hispanismo; Cervantes.

\title{
Title: The Association of Cervantistas, 25 years
}

\begin{abstract}
On the occasion of twenty-fifth anniversary of the Association of Cervantes's birth, a number of researchers wanted to offer a synthesis on the contribution of this institution to hispanism. This dossier includes evocations of some of those involved in its creation, as well as its two presidents, Alberto Sánchez and José María Casasayas. Also includes an analysis and assessment of their academic meetings and the many publications derived from them, as well as a preview of his next goals and projects.
\end{abstract}

Key words: Association of Cervantistas; Cervantism; Hispanism; Cervantes. 